ADRIANO BLATTNER

MARTINHO

\title{
OS MOMENTOS LITERÁRIOS DA INDIVIDUALIDADE MODERNA NA FENOMENOLOGIA DO ESPÍRITO DE HEGEL
}

Dissertação apresentada ao Programa de Pós-graduação em Filosofia da Faculdade de Filosofia, Letras e Ciências Humanas da Universidade de São Paulo, como requisito para obtenção do título de Mestre.

Linha de Pesquisa: Filosofia Moderna, Estética

Orientador: Prof. Dr. Marco Aurélio Werle 


\author{
UNIVERSIDADE DE SÃO PAULO \\ FACULDADE DE FILOSOFIA, LETRAS E CIÊNCIAS HUMANAS \\ DEPARTAMENTO DE FILOSOFIA
}

OS MOMENTOS LITERÁRIOS DA INDIVIDUALIDADE MODERNA NA FENOMENOLOGIA DO ESPÍRITO DE HEGEL

[VERSÃO CORRIGIDA]

autor: Adriano Blattner Martinho

orientador: Prof. Dr. Marco Aurélio Werle

São Paulo, maio de 2010 
À pequena Teresa. 
Agradeço à Fundação de Amparo a Pesquisa do Estado de São Paulo por distinguir meu trabalho. 


\section{BANCA EXAMINADORA}

PROF. DR. MARCO AURÉLIO WERLE (USP)

PROF. DR. VLADIMIR SAFATLE (USP)

PROF. DR. ERICK LIMA (UNB) 


\section{SUMÁRIO}

19a PARTE: CRISE DA FUNDAMENTAÇÃO METAFÍSICA DA SUBJETIVIDADE

$\begin{array}{lr}\text { CAPÍTULO I - Individualidade e Idealismo } & 10\end{array}$

CAPÍTULO II - Individualidade e Fenomenologia do Espírito $r$

$\begin{array}{ll}\alpha) \text { Plataforma filosófica da obra } & 15\end{array}$

ß) O lugar da individualidade na fenomenologia $\quad 27$

ү) Fenomenologia X Fundamentação $\quad 29$

- Paralogismo na Crítica da Razão Pura: o estatuto problemático do sujeito transcendental 34

- Paradoxo crítico e resolução fichteana: estatuto categorial do sujeito transcendental 41

- Hegel e a refutação do conceito transcendental de sujeito 46

CAPÍTULO III - Literatura e experiência da consciência $\quad 53$

2ª PARTE: OBSERVAÇÃO FENOMENOLÓGICA DA INDIVIDUALIDADE

CAPÍTULO I - Crítica da representação dualista do homem $\quad 60$

CAPÍTULO II - Da noite da possibilidade ao dia da presença $\quad 62$

\begin{tabular}{ll}
$\alpha)$ Psicologia & 62 \\
\hline B) Prenologia
\end{tabular}

ß) Frenologia e Fisiognomonia $\quad 67$

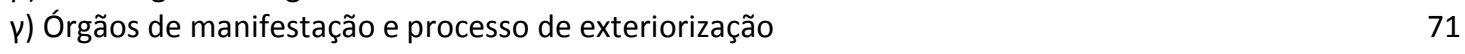

CAPÍTULO III - A efetivação da consciência-de-si racional através de si mesma 73

$\begin{array}{ll}\alpha) \text { Fausto: o prazer e a necessidade } & 77\end{array}$

ß) Karl von Moor: a lei do coração e o delírio da presunção 83

ү) Dom Quixote: a virtude e o curso do mundo $\quad 94$

$\begin{array}{lr}\text { CONCLUSÃO } & 101\end{array}$

$\begin{array}{lr}\text { BIBLIOGRAFIA } & 107\end{array}$ 


\begin{abstract}
By highlighting major statements from the Phenomenology of Spirit on the individuality category, this inquiry intends to appreciate the role of literature in understanding the so-called "realization of racional self-consciousness through itself". In the first part, Hegel's great work is presented as an attempt to depose the transcendental status of subjectivity in modern philosophy. In the second one, it's shown how, against other current disciplines, Hegel conceives the human self-creation of individuality, based on the experience of three famous literary characters: Faust, Karl von Moor and Don Quixote.
\end{abstract}

Keywords: Hegel, Phenomenology of Spirit, individuality, literature

\title{
RESUMO
}

Salientando asserções principais da Fenomenologia do Espírito sobre a categoria da individualidade, este estudo pretende avaliar o papel da literatura na compreensão da assim chamada "efetivação da consciência-de-si racional através de si mesma." Na primeira parte, a grande obra de Hegel é apresentada como uma tentativa de destituir o estatuto transcendental da subjetividade na filosofia moderna. Na segunda, mostra-se como Hegel concebe, contra outras disciplinas em voga, a auto-criação humana da individualidade, baseado na experiência de três famosas personagens literárias: Fausto, Karl von Moor e Dom Quixote.

Palavras-chave: Hegel, Fenomenologia do Espírito, individualidade, literatura 
Das Gefühl unserer Würde und unserer Kraft steigt, wenn wir uns sagen, was jeder unter uns sich sagen kann: mein Daseyn ist nicht vergebens und zwecklos; ich bin ein nothwendiges Glied der grossen Kette, die von Entwickelung des ersten Menschen zum vollen Bewusstseyn seiner Existenz bis in die Ewigkeit hinausgeht; alles, was je mals gross und weise und edel unter den Menschen war, - diejenigen Wohlthäter des Menschengeschlechts, deren Namen ich in der Weltgeschichte aufgezeichnet lese, und die mehreren, deren Verdienste ohne ihre Namen vorhanden sind, - sie alle haben für mich gearbeitet; - ich bin in ihre Ernte gekommen; - ich betrete auf der Erde, die sie bewohnten, ihre Segen verbreitenden Fusstapfen. Ich kann, sobald ich will, die erhabene Aufgabe, die sie sich aufgegeben hatten, ergreifen, unser gemeinsames Brudergeschlecht immer weiser und glücklicher zu machen; ich kann da fortbauen, wo sie aufhören mussten; ich kann den herrlichen Tempel, den sie unvollendet lassen mussten, seiner Vollendung näher bringen.

FICHTE, Johann Gottlieb

Vorlesungen über die Bestimmung des Gelehrten (1794)

O sentimento da nossa dignidade e da nossa força cresce, se nos dissermos o que cada qual dentre nós a si mesmo pode dizer: o meu ser não é vão e sem finalidade; sou um elo necessário da grande cadeia que se estende desde a chegada do primeiro homem à plena consciência de sua existência até a eternidade; tudo o que já houve de grande, de sábio e de nobre entre os homens - os benfeitores do gênero humano, cujos nomes leio gravados na história do mundo, e aqueles outros mais numerosos, cujas contribuições subsistem anonimamente - todos eles trabalharam para mim; eu vim em sua colheita; sobre a terra que habitaram, sigo as pegadas que espalham suas bênçãos. Posso, tão logo queira, abraçar a sublime tarefa da qual se encarregaram: fazer cada vez mais sábio e mais feliz o nosso comum gênero de irmãos, posso prosseguir construindo ali donde eles precisavam parar, posso aproximar da perfeição o templo magnífico que tiveram de deixar inacabado.

FICHTE, Johann Gottlieb

Preleções sobre a Determinação do Sábio (1794) 


\section{$1^{\text {a }}$ PARTE: CRISE DA FUNDAMENTAÇÃO METAFÍSICA DA SUBJETIVIDADE}




\section{CAPÍTULO I Individualidade e Idealismo}

Buscar em Hegel a compreensão do modo de efetivação da individualidade pode parecer infrutífero, se o esforço necessário for comedido ao sabor do vendaval que propaga a má reputação do filósofo quanto a este tema. A recepção do legado hegeliano, a despeito de sua miríade de matizes, consolidou um juízo bastante difuso acerca da inépcia de Hegel para responder a essa ordem de exigências: a individualidade seria justamente o calcanhar de Aquiles de uma filosofia mais disposta a perpetrar quaisquer sacrifícios para subjugar os múltiplos aspectos da vida a um princípio unitário.

$\mathrm{Na}$ atualidade, tal juízo se tornou um dos maiores entraves à penetração no pensamento de Hegel, porque desengana de procurar respostas ali onde residem as perguntas, e acaba por deixar intocada a riqueza daquilo que contesta. "Nada mais fácil do que julgar o que tem conteúdo e solidez; apreendê-lo é mais difícil; e o que há de mais difícil é produzir sua exposição, que unifica a ambos." Essa máxima de Hegel bem poderia referir-se ao modo como se veio a tratar sua própria filosofia. Em virtude de seu conteúdo e solidez, nada mais fácil que julgá-la - principalmente se o juízo libera da notória dificuldade de apreendê-la e expô-la.

Estas páginas recuperam uma temática do pensamento hegeliano sobre a qual incide profusão desfavorável de suposições judiciosas. Mas nem por isso a dilucidação exegética, promovida doravante, pecará pela ingenuidade de atribuí-las ao simples desconhecimento da letra do autor. O breve apanhado de Jaeschke nos delimita o terreno controvertido em que, desde sempre, o debate sobre Hegel precisa se firmar:

\footnotetext{
Hegel: para o jovem Karl Marx, ele representa a "filosofia universal de nosso tempo"; ainda por volta do final do século XIX, para Carl Ludwig Michelet, o último de seus seguidores, ele é o "irrefutado filósofo universal". Os seus contemporâneos já o denominam o "Aristóteles alemão" ou o "Proklos alemão", e, no século XX, Karl Barth propôs a questão - por mais que retórica - de por que ele não teria se tornado, para o protestantismo, o mesmo que Tomás de Aquino para a igreja romana. Por outro lado: para Schopenhauer ele é um mero "charlatão" - e muito mais, e pior; Friedrich Schlegel o define como um Fichte castrado e macaqueado, "estupidez absoluta para com todo o divino". Também Schelling recorre ao reino animal: Hegel seria um "espírito negativo", prosaico de alto a baixo, recaído "no simiesco", que, todavia, "torna-se divertido, tão logo monta na negação". Um quarto de século após a morte de Hegel,
}

\footnotetext{
${ }^{1}$ HEGEL, G. W., Fenomenologia do Espírito, Prefácio, p. 27 (13). Em todas as notas de rodapé referentes a citações da Fenomenologia do Espírito, ao longo do presente estudo, indiquei entre parênteses, após o número de página da tradução brasileira, o número da página correspondente na edição alemã da Editora Suhrkamp.
} 
Rudolf Haym lança o retrato imaginário do Hegel berlinense como o de uma supremacia arrogante, saciada e satisfeita consigo mesma: "Agraciado pelo favor dos poderosos, regalado com o sucesso e com a glória de sua obra - ele, um ditador filosófico por sobre a Alemanha viu-se no objetivo de sua ambição”. E após Hegel ter tido antes atestada a incompatibilidade de seus princípios filosóficos com o Estado prussiano, recebia ele agora, retroativamente, o seu diploma lavrado de nomeação a "filósofo estatal da Prússia". No século XX, ele é estilizado como o pilar intermediário que suporta a fatalidade da história do espírito alemão: de Lutero a Hitler mediante Hegel. E esta safra é curta - demasiado curta, se comparada ao número das searas cultivadas em dois séculos, sobretudo as malcheirosas. Contudo, ela já faculta uma impressão da luta que foi e que é conduzida sobre a obra de Hegel. ${ }^{2}$

Esteja o leitor prevenido de que tem sob os olhos uma franca arremetida ao meio dessa incontornável batalha - sem que a confissão de empreendê-la a partir de posição particular implique renúncia à pretensão de verdade que acompanha mesmo os enganos do verdadeiro saber. Batalha a cujo campo Hegel chega ainda profundamente marcado pelo retrato onipresente do "ditador filosófico" que se tem repintado com tintas frescas desde Rudolf Haym.

Recuperar a categoria da individualidade em Hegel há de ao menos desvanecer essa imagem. Embora fuja ao escopo deste trabalho, a tarefa de apurar o sentido geral da filosofia hegeliana não pode ser completamente evitada. Pois quem toca a parte toca também o todo; além de que, aqui, não se toca uma parte qualquer, mas justamente aquela que pode ser considerada, segundo Hypollite, "o problema central do hegelianismo", uma vez que "o espírito não é o Universal abstrato, é individual". ${ }^{3}$ No seu sentido mais amplo, tal afirmação significa que a filosofia hegeliana assume como núcleo o propósito de reconduzir os universais a determinações singulares. E assim ela dá corte e seguimento ao fio que norteia as diligências ancestrais do pensamento moderno: cunhar, para os diversos campos da experiência humana, critérios e cometimentos que permitam submeter a objetividade às necessidades de fundamentação subjetiva. Hegel acredita que "o homem deve possuir por si mesmo, em geral, uma consciência da diferença entre o bem e o mal: as determinações éticas, como as religiosas, não lhe devem fazer a exigência de serem seguidas só como leis externas e preceitos de uma autoridade, mas devem ter assentimento,

\footnotetext{
${ }^{2}$ JAESCHKE, Walter., Hegel Handbuch, p. XI. Tradução minha.

${ }^{3}$ HYPPOLITE, Jean., Gênese e Estrutura da Fenomenologia do Espírito de Hegel, p. 66.
} 
reconhecimento ou fundamento próprio no seu coração, na sua disposição de ânimo, na sua consciência, inteligência etc." 4

Veremos como Hegel organiza sua reflexão com base no fracasso das tentativas de fundamentar a experiência em uma subjetividade formal - cujo conceito, por conseguinte, deve ascender ao de uma subjetividade infinita. E não é segredo que essa solução hegeliana desperta resistências e reações de todas as ordens. Freqüentemente se denuncia o sufocamento da individualidade pela filosofia do espírito, e mesmo os mais recentes esforços para ressaltar a dinâmica particular dos processos de reconhecimento não deixam de restaurar o velho retrato. Seja qual for o feitio do Hegel que se tenha em mente, impende notar, desde já, que somente apesar de sua plataforma pode a filosofia hegeliana ser acusada de proscrever a consciência subjetiva da fundamentação dos sistemas políticos, lógicos, éticos e estéticos.

O tão propalado descaso da filosofia hegeliana com a individualidade ainda se nutre do hábito de aduzi-la sob a alcunha lacônica de "idealismo", que tem servido menos para sintetizar os diversos combates da escola alemã contra a abstração da razão do que para imputar a Hegel algo como um esquema de dedução transcendental das figuras da realidade - muito avesso, por sinal, à essência do seu programa filosófico e à sua própria crítica do idealismo de seus contemporâneos e predecessores. É que o uso impróprio carrega o termo com a conotação daquela primazia da teoria sobre a prática que Hegel mesmo não se dedicou senão a refutar com veemência. Essa diretriz fundamental do idealismo hegeliano não passará despercebida de quem se dispuser a percorrer os seus caminhos. ${ }^{5}$

Parece-nos remontar a Kant a condenação do idealismo enquanto doutrina filosófica que pensa poder prescindir da experiência para conhecer. Por isso cabe anunciar a diferença

\footnotetext{
${ }^{4}$ HEGEL, G. W., Enciclopédia das Ciências Filosóficas em Compêndio, vol. III, § 503, p. $482-483$ [tradução por mim modificada]

${ }^{5}$ Não surpreende, pois, encontrá-la registrada no depoimento de Hyppolite:
}

As doutrinas filosóficas não são para Hegel doutrinas abstratas, são modos de viver: o estoicismo, o ceticismo, a consciência infeliz, a visão moral do mundo não serão, como veremos adiante, exposições de um certo pensamento filosófico, mas experiências da vida; a universalidade humana de tais doutrinas só encontra sua realização na experiência vivida por uma consciência particular. Inversamente, porém, essa experiência vivida só encontra seu sentido em um pensamento universal. (...) Este esforço para reunir o universal e o particular na individualidade espiritual é o que confere interesse ao hegelianismo e, no interior do hegelianismo, à Fenomenologia. (Gênese e Estrutura da Fenomenologia do Espírito, p. 68) 
entre o idealismo hegeliano e o conceito kantiano de idealismo. Kant rechaça no idealismo a adoção de um "princípio puramente intelectual para a determinação da minha existência." ${ }^{\circ}$ Refere-se, sobretudo, a Descartes, que preceituara assumir-se de início a certeza de si como o único saber fidedigno, dando por indemonstrável a existência das coisas exteriores. Descartes supunha que a proposição cogito ergo sum forneceria um conhecimento imune às variações do mundo empírico, pois deduzido sem nenhuma interferência da sensibilidade. Na Crítica da Razão Pura, Kant emprega esse conceito de idealismo não apenas para classificar Descartes, mas também para embargar caminhos que conduzam a recaídas cartesianas.

Hegel, por sua vez, reconhece sob a designação geral de idealismo os esforços difusos de uma linhagem filosófica empenhada em conceber o pensar por contraposição ao ser, de modo que o subjetivo e o objetivo existam em unidade. Sem dúvida, Hegel se alia a Kant no intento de refutar a possibilidade de um princípio metafísico. Mas ele não considera o idealismo uma via em si mesma falsa para a reflexão. Tampouco se arvora defensor de suas teses. Hegel se opõe ao ponto de vista que "não concebe a diversidade dos sistemas filosóficos como desenvolvimento progressivo da verdade, mas só vê na diversidade a contradição."7

Já no artigo Fé e Saber, de 1802, Hegel procura distinguir-se das tendências idealistas em voga. Aponta em Kant a presença de um "idealismo crítico"8 - a semente do idealismo no interior da filosofia crítica - que, todavia, devido ao compromisso de Kant com o contingenciamento do saber à finitude da razão, teria se degenerado em um "idealismo transcendental", ainda no âmbito da própria filosofia kantiana. Este persistiria, depois de Kant, nas saídas encontradas por discípulos que tomaram consciência das dicotomias kantianas, mas não conseguiram efetivamente superá-las: Jacobi as teria solucionado com uma unificação subjetiva; e Fichte, com a transposição dessa unidade subjetiva para a objetividade. Posteriormente, na Fenomenologia, também a solução de Schelling será recusada em uma crítica geral do "idealismo vazio"10 - aquele que, apesar de

\footnotetext{
${ }^{6}$ KANT, I., Crítica da Razão Pura, Capítulo primeiro do Livro Segundo da Dialética Transcendental, p. 271.

${ }^{7}$ HEGEL, G.W., Fenomenologia do Espírito, Prefácio, p. 26 (12).

${ }^{8}$ Id., Fé e Saber, p. 44.

${ }^{9}$ Ibid., p. 44.

${ }^{10}$ Id., Fenomenologia do Espírito, V- "Certeza e verdade da razão”, p. 177 (184). Ver, a propósito, os $\S 15$ e 16 do Prefácio em conjunto com as primeiras páginas do capítulo citado.
} 
todos os manejos, ainda permanece dependente da necessidade de postular uma razão pura, seja sob a figura de um Eu totalizador, seja sob a de um Absoluto intuitivo, imediatamente isento da oposição entre sujeito e objeto. Para Hegel, o autêntico idealismo é aquele capaz de determinar o conceito também na medida em que este aparece como "o ideal, ou seja, como o negativo para a realidade." 11

Voltado a um modelo de ciência baseado na aplicação de leis racionais sobre dados empíricos, Kant relegara o ideal ao ponto cego da razão, à figura do irrepresentável, gerada na consciência pela escrupulosa tentativa de conhecer um objeto que não se oferece à intuição. Do ponto de vista kantiano, para qual os únicos objetos passíveis de conhecimento são os objetos sensíveis, o idealismo seria necessariamente uma restauração metafísica, pois empossa o ideal na proa da ciência - que deixaria então de perceber o existente para entregar-se ao uso incondicionado da imaginação. Para Hegel, contudo, não se trata de abandonar a experiência, mas de encontrar um modo mais abrangente de incorporá-la à reflexão.

\section{CAPÍTULO II \\ Individualidade e Fenomenologia do Espírito}

Escavação acurada da Fenomenologia do Espírito mostra que a categoria da individualidade está incrustada em veio assaz mais opulento do que se poderia supor. Para hauri-lo, entretanto, antes há de se rachar a crosta. Como se sabe, a rocha é bem dura. Mas o veio procurado, em compensação, deita vestígios desde a superfície. Já no Prefácio, de chofre, a centralidade do indivíduo finca o eixo da obra como um todo.

Que a fenomenologia se ocupe da experiência individual é um dado que compreensivelmente escapa ao leitor de primeira viagem. No decorrer da jornada, conforme Hegel nos leva de nossas certezas mais rudimentares pelos sinuosos labirintos da consciência afora, o cerne da proposta facilmente perde visibilidade sob o jorro copioso de injunções filosóficas.

Convém lembrar que o Prefácio foi escrito só depois do último capítulo, e cumpre a função de esclarecer o ponto de partida à luz do ponto de chegada. É ali - na avaliação do

\footnotetext{
${ }^{11}$ Id., Fé e Saber, p. 29.
} 
próprio Hegel - onde a categoria da individualidade aparece promovida a fulcro da reflexão subseqüente. Desta feita, mais do que a um fragmento, o tema nos remete à compreensão global da obra. Comecemos por esta.

a) Plataforma filosófica da obra

A Fenomenologia do Espírito, de 1807, é indubitavelmente uma das mais incríveis realizações da história da filosofia. A perplexidade que ela inspira não se deixa definir a baixo custo. Em primeiro lugar, porque sua escrita é absolutamente peculiar: em vez de designar fatos e coisas, nesta obra, o fraseado hegeliano como que se utiliza de si mesmo para exprimir um conteúdo próprio. A sensação provocada pela leitura é a de que o pensamento não simplesmente discorre sobre algo que acontece, mas realiza, ele próprio, este acontecer; de que nos ocupamos, pois, da própria efetivação do real, e não de um discurso a respeito dela. Em segundo, porque esse trabalho conceitual ganha dimensões cada vez mais inauditas, de modo que o avanço da obra parece contemplar com profundidade todos os principais tópicos de epistemologia, lógica, ética, política, história, arte, religião, linguagem, psicologia, metafísica, filosofia da natureza e outros. E a maneira de dispô-los passa ao largo de uma compilação enciclopédica, de um diálogo aberto com a tradição ou mesmo dessa divisão temática a que acabamos de recorrer. Do contrário, Hegel condensa os mais diversos assuntos em excursos repletos de transições abruptas, e só muito raramente cita um autor.

Mas em que consiste, afinal, a plataforma filosófica que permite encadear tantos temas em uma síntese tão densa do saber? Digamos que essa não é exatamente uma daquelas perguntas que se possa tirar da frente como teias de aranha. Trata-se da pergunta que a própria Fenomenologia do Espírito chega a formular, mas só após tê-la respondido, e que revela o sentido mesmo da obra, qual seja: um vastíssimo ataque de múltiplos e inesperados flancos à noção de subjetividade transcendental, ao longo do qual Hegel apresenta, pouco a pouco, a concepção de intrigante originalidade destinada a suplantá-la: "entender e exprimir o verdadeiro não como substância, mas também, precisamente, como sujeito." 12

\footnotetext{
${ }^{12}$ Id., Fenomenologia do Espírito, Prefácio, p. 34 (22-23).
} 
Hegel ressalta, no Prefácio, que tal concepção não é passível de ser justificada senão pela completa exposição da experiência da consciência - empreitada de que se ocupa a obra, e que não nos convém avocar, ao menos em toda sua extensão. Muito já se escreveu para explicar gênese e estrutura da Fenomenologia do Espírito. Decerto não seria ocioso reviver aqui a bela narrativa de sua turbulenta publicação em fascículos, com Hegel concluindo, às pressas, o último deles - o famoso Prefácio - no afã de despachá-lo ao editor pela última cavalaria postal que partiria de Jena, a salvo das iminentes tropas napoleônicas. Este caminho, todavia, levaria longe demais, pois logo nos sentiríamos premidos a enveredar pelos problemas filosóficos assimilados a cada novo capítulo, ou a discutir a organização com que o livro se consolidou para a posteridade, apesar de Hegel haver ulteriormente decidido desmembrar o texto em duas partes, para a primeira edição de suas obras completas, que ele não logrou tirar do prelo, abatido pela cólera.

Atenhamo-nos, desta feita, ao foco de nosso interesse. A propositura hegeliana de que "a substância é essencialmente sujeito"13 significa que Hegel não consente com nenhuma forma de representação para qual "um ser originário do espírito há que ser precisamente enunciado também como algo tal, que não exista como ser." ${ }^{14}$ Isto é: para Hegel, não há nenhuma origem fora da determinidade; a substância contém em si inclusive a subjetividade como um sujeito existente; logo, o conceito deve trabalhar para enunciar o abstrato como aparência de indeterminação.

O abstrato aparece inicialmente para o puro conceito como o ser simples de uma essência crivada na substância. Também a substância, por conseguinte, aparece como a igualdade-consigo-mesma onde esta essência repousa, ou perante a qual aquele ser simples se sustém. Entretanto, a substância não é em si uma determinidade inerte; "a substância viva é o ser, que na verdade é sujeito, ou - o que significa o mesmo - que é na verdade efetivo, mas só na medida em que é o movimento do pôr-se-a-si-mesmo, ou a mediação consigo mesmo do tornar-se outro." 15 A verdade do ser enquanto sujeito é a autodiferenciação efetiva da sua efetividade. Por isso, a essência verdadeira do ser simples só

\footnotetext{
${ }^{13}$ Ibid., p. 39 (28).

${ }^{14}$ Id., Fenomenologia do Espírito, V, A-c-“'Observação da relação da consciência-de-si com sua efetividade imediata: fisiognomia e frenologia", p. 242 (255).

${ }^{15}$ Id., Fenomenologia do Espírito, Prefácio, p. 35 (23).
} 
pode se tornar uma verdade para o conceito quando este empreende o movimento constitutivo da substância em si.

O trabalho do conceito consiste, pois, em sair daquela "simplicidade do pensar" que fixa para si a essência como um ser abstrato e estranho à sua própria determinação. "A determinidade, de início, aparenta ser apenas porque se refere a Outro; e seu movimento, imposto por uma potência estranha." 17 Esse Outro é o ser que passa da determinidade ao conceito puro como um simples; ou, inversamente, o ser simples desse Outro é o conceito cuja pureza repele a determinidade. Mas "a natureza do que é está em ser, no seu próprio ser, seu conceito."18 O entendimento ou "simples pensar" não consegue conceber a passagem ao conceito como um movimento interior à substância: para ele, por conseguinte, a intuição cria uma subjetividade representada como essencialmente inefetiva, que se impõe como condição ao movimento da efetividade, e o conceito permanece retido em si mesmo, incapaz de atravessar a linha divisória que o separa da sua determinação essencial. "A filosofia, do contrário, não considera a determinação inessencial, mas a determinação enquanto essencial. Seu elemento e seu conteúdo não é o abstrato e o inefetivo, mas sim o efetivo, que se põe a si mesmo e é em si vivente: o ser-aí em seu conceito." ${ }^{19}$

O pensar conceitual - que Hegel denomina "filosofia especulativa" ou apenas "filosofia" - não se subordina à proibição de revelar a essência dos fenômenos, decretada pela analítica dos pressupostos de validade do pensamento. E nisto não há qualquer profissão de fé em uma razão dotada de poder ilimitado para enxergar a coisa-em-si transparecer por detrás da cortina fenomênica. Do contrário, a inadequação entre a essência e a aparência deve ser assumida pela autêntica reflexão. É justamente devido a essa opacidade da apercepção que, para Hegel, "o que importa no estudo da ciência é assumir o esforço tenso do conceito" 20 - sob pena de se relegar o pensar confinado a um giro sobre si mesmo, retrocedendo sempre à eterna discussão sobre os seus próprios mecanismos internos. Trata-se, antes de tudo, de ultrapassar a "crítica da razão" - com a ressalva de que Hegel compreende isso como algo mais amplo do que a filosofia kantiana; ou melhor, compreende a filosofia kantiana como síntese filosófica de toda uma ordem de

\footnotetext{
${ }^{16}$ Ibid., p. 60 (54).

${ }^{17}$ Ibid., p. 60 (54).

${ }^{18}$ Ibid., p. 60 (54).

${ }^{19}$ Ibid., p. 53 (46).

${ }^{20}$ Ibid., p. 61 (56).
} 
conhecimento que substitui o real pela representação do real. Daí então se dedicar boa parcela do Prefácio a embargar a aptidão da matemática e da mecânica para fornecer um modelo geral de fundamentação do saber.

Ocorre que "o outro modo de pensar, o raciocinar," 21 pode preterir os pesados encargos do conceito pela leveza de operar solto, representando-se como liberdade a sua desvinculação do conteúdo. Neste caso, "exige-se da vaidade o esforço de abandonar tal liberdade; e, em vez de ser o princípio motor arbitrário do conteúdo, mergulhar essa liberdade nele, fazer que se mova conforme sua própria natureza, isto é, através do Si como seu próprio conteúdo; e contemplar esse movimento." 22 Para aderir ao pensar conceitual é preciso, portanto, que a liberdade de pensar se deixe condicionar pelas contingências da efetivação de um conteúdo que se efetiva como o $\mathrm{Si}$; isto é, um conteúdo em cuja determinação essencial convergem desde sempre o sujeito e a substância, a liberdade e a necessidade. Saem de cena aqueles raciocínios engenhosos, mas arbitrários, que usavam a liberdade crítica apenas para estatuir formas e categorias como pressupostos da experiência. Entra, em seu lugar, o movimento conceitual, que imerge na experiência independentemente de atender ou não a tais pressupostos. O zelo pela objetividade do conteúdo não pode consistir em confiná-lo a um campo previamente estabelecido pelo pensamento, que deve, do contrário, "renunciar a suas próprias incursões no ritmo imanente dos conceitos; não interferir nele através de seu arbítrio e de sabedoria adquirida alhures eis a discrição que é, ela mesma, um momento essencial da atenção ao conceito." ${ }^{23}$ Atenção que não se confunde com uma superioridade analítica pretensamente isenta dos apelos particulares inerentes ao objeto e às dificuldades de determiná-lo. Pois "o conhecimento científico requer o abandono à vida do objeto; ou, o que é o mesmo, exige que se tenha presente e se exprima a necessidade interior do objeto. Desse modo, indo a fundo em seu objeto, esquece aquela vista geral que é apenas a reflexão do saber sobre si mesmo a partir do conteúdo." 24

O mergulho na vida do objeto confere ao conhecimento o estatuto de ciência, cujo advento coincide com este momento da história do espírito em que se rompe com a

\footnotetext{
${ }^{21}$ Ibid., p. 61 (56).

${ }^{22}$ Ibid., p. 61 (56).

${ }^{23}$ Ibid., p. 61 (56).

${ }^{24}$ Ibid., p. 58 (52).
} 
representação do sujeito enquanto mera faculdade intelectiva. Desde Descartes, a busca por um fundamento confiável para o saber persistia na estratégia de submeter o conhecimento ao crivo da razão, separando-o das controversas referências às coisas, até que restasse apenas aquilo cuja validade se pudesse assegurar sem margem de dúvida. Essa estratégia conduzia a privar o entendimento de toda diferença para consigo e a tomar o seu simples exercício neste estado puro por uma evidência suficiente da qual não seria possível retroceder logicamente: cogito ergo sum. ${ }^{25}$ Eis que surge o pensar exilado do ser, a clivagem da substância. Porém, para a verdadeira ciência, a consciência desse sujeito que deriva sua própria existência do puro pensar aparece como sendo o pensamento determinado de um sujeito existente desde antes dessa derivação pela qual ele toma consciência de si. Vemos, portanto, que Hegel assesta a filosofia contra a essência metafísica da subjetividade. Elucidados os processos constitutivos da consciência e da razão, aquele sujeito abstrato se revela uma abstração do sujeito, cuja verdade consiste em ser não apenas um Eu que pensa, mas também um sujeito prático, ativo, que radica na diferença consigo e estabelece identidade com o outro.

Para instaurar o elemento do conceito, a filosofia conserva o que havia de verdadeiro naquela representação abstrata do sujeito que ela chega a assimilar e a refutar. Um aspecto central dessa apropriação crítica reside na reconstrução da negatividade enquanto conceito. Hegel observa que o entendimento exerce a negação do conteúdo, mas de modo ainda parcial. O entendimento põe para si a coisa como algo diferente dela. A negação é a produção desta diferença da coisa em relação a si mesma. Porém, para o entendimento, a diferença produzida pela negação é a forçosa manifestação da coisa como uma outra coisa, e não o tornar-se outro da coisa. $\mathrm{O}$ entendimento nega a coisa e obtém duas coisas diferentes, cada qual idêntica apenas a si mesma. A negação, à luz do entendimento, não passa de negação pura ou simples: a negação que separa de si o conteúdo negado como uma essência alheia à intelecção; que retém do conteúdo somente a

\footnotetext{
${ }^{25}$ Penso, logo existo - a divisa cartesiana. A propósito da sua concepção:

Se alguém se propuser como questão examinar todas as verdades para cujo conhecimento basta a razão humana - e parece-me que isso deve ser feito uma vez na vida por todos os que se empenham seriamente em alcançar a sabedoria - seguramente encontrará, de acordo com as regras fornecidas, que nenhum conhecimento pode preceder o do entendimento, já que é dele que depende o conhecimento de tudo mais, e não o inverso. (DESCARTES, René. Regras para a Orientação do Espírito, p. 50-51)
} 
aniquilação fenomênica da sua essência, na forma de uma nova identidade indeterminada. "De uma parte, o procedimento raciocinante se comporta negativamente em relação ao conteúdo apreendido; sabe refutá-lo e reduzi-lo a nada. Essa intelecção de que o conteúdo não é assim é algo puramente negativo; é o ponto terminal que a si mesmo não ultrapassa rumo a novo conteúdo, mas para ter de novo um conteúdo, deve arranjar outra coisa, seja donde for. É a reflexão do Eu vazio, a vaidade do seu saber." ${ }^{26}$ A intelecção pela negação pura, portanto, limita o conhecimento à cognição. O entendimento ignora como elaborar conceitualmente a essência do objeto, e por isso considera a abstração que acede à representação como o maior grau possível de determinação. Conseqüentemente, não é capaz de dar continuidade ao saber: a atividade negativa do entendimento se resume a coletar o diverso, e a sua vaidade está em possuir uma imensa coleção de representações estáticas. O seu saber do objeto não estabelece mediação com a experiência de um outro objeto. "Ao contrário, como já foi mostrado, no pensar conceitual o negativo pertence ao conteúdo mesmo e - seja como seu movimento imanente e sua determinação, seja como sua totalidade - é o positivo. O que surge desse movimento, apreendido como resultado, é o negativo determinado e, portanto, é igualmente um conteúdo positivo." ${ }^{27}$ Assim, à luz da filosofia especulativa, aquela intelecção puramente negativa é a inconsciência de si da reflexão conceitual, a qual, por sua vez, extrai a diferença do interior do próprio conteúdo aparentemente auto-idêntico e a conduz para uma efetividade oposta. Na verdade, a essência que parecia perdida para o entendimento está realizada integralmente em seu seroutro. A operação lógica que põe para si a diferença em relação ao conteúdo como um outro essencial a ele é a negação determinada. Se a negação do conteúdo preserva em si a diferença negada, em vez de deixá-la para trás, então a reflexão passa a fazer dessa diferença, para si, mais do que um mero fenômeno, isto é: passa a concebê-la como uma aparência que, embora difira do conteúdo, constitua igualmente o seu modo de ser. Pois, na aparência negativa, a positividade do conteúdo reside na forma de um outro conteúdo positivo que fornece, enquanto tal, um novo objeto para a negação. Assim, mediante a negação determinada, a essência adquire uma aparência e essa diferença negativa do conteúdo em relação a si mesmo, o ponto terminal onde o entendimento se detinha, torna-se

\footnotetext{
${ }^{26}$ HEGEL, G.W., Fenomenologia do Espírito, Prefácio, p. 62 (56).

${ }^{27}$ Ibid., p. 62 (57).
} 
para o pensar conceitual um objeto positivo em que a essência se exprime e no qual, por conseguinte, o aprimoramento da reflexão deve buscá-la. Por isso, a atividade do pensar conceitual consiste em apropriar-se continuamente das manifestações da essência; compreendê-la não pode ser senão compreender o processo pelo qual ela se determina. Entretanto, o "entendimento raciocinante" vê em cada momento determinado uma obliteração do caminho para o essencial.

Mas é justamente enquanto aparência que a essência se explicita em algo passível de se oferecer ao pensar como objeto. Mais do que desfazer o equívoco segundo o qual a diferença entre a essência e a aparência impediria o conhecimento da verdade, Hegel pretende ainda erigir essa diferença em momento necessário e constitutivo do verdadeiro saber, cujas investigações, vencendo a paralisia de indagar pelo que permanece oculto, devem antes passar a examinar o que aparece, pois o que aparece é precisamente aquilo mesmo que a princípio se ocultava. A essência só se revela para o pensar que a procura na desidentidade de si mesma. Por conseguinte, o modo profícuo de examinar o conteúdo consiste em produzir a sua diferença pela reflexão - e daí a importância da negação determinada. O entendimento, porém, acaba por fazer exatamente o contrário, já que constitui para si diferenças que não passam de puras identidades. Este procedimento característico do entendimento recebe as suas formulações mais bem acabadas em "todo o aparato científico oferecido pela matemática - explicações, divisões, axiomas, séries de teoremas e suas demonstrações, princípios com suas demonstrações e conclusões." 28

Em 1687, Isaac Newton fornecera amplas bases desse aparato nos Princípios Matemáticos da Filosofia Natural, sua obra magna, aclamada pela posteridade como sumo exemplo da perfeição científica. No capítulo "Força e Entendimento", da Fenomenologia do Espírito, Hegel sustenta que a lei da gravitação universal enuncia o padrão de racionalidade de todo o mundo moderno, onde se erigiu em ciência um aparato meramente descritivo da lógica fenomênica. (Vale frisar, a propósito, que as leis de conduta, jurídicas ou morais, possuem a mesma estrutura lógica das leis físicas, matematicamente enunciadas.) Hegel considera a lei uma forma parcial e adstringida de racionalização das contingências porque ela enuncia somente o modo de se relacionar de grandezas envolvidas em modelos de processos, fazendo abstração das próprias relações efetivas entre os

\footnotetext{
${ }^{28}$ Ibid., p. 54 (47).
} 
verdadeiros elementos implicados na ação. Assim, por exemplo, na queda de uma pedra, a lei, em si, considera apenas a constância com que o peso se relaciona com a massa $(\mathrm{P} / \mathrm{m}=$ g). Não há lugar na lei para a própria pedra. Supondo preencher-se com dados da realidade, a lei se limita a manejar e remanejar grandezas no interior de si mesma. $\mathrm{O}$ evento singular se torna objeto de uma analítica de representações. A efetividade não passa à legalidade; ou, ainda, passa tão-somente à custa de perder o seu caráter efetivo. Eis a negação simples operando novamente os procedimentos do pensar. Daí as notórias restrições hegelianas a Newton, cuja cosmologia racionalizou as leis empíricas de Kepler e Copérnico, que descreviam o movimento das esferas celestes segundo a regularidade aferida em observações astronômicas. "A unificação de todas as leis na atração universal não exprime conteúdo mais amplo que justamente o mero conceito da lei mesma, que aí se põe como essente." ${ }^{29}$ Com a lei geral da gravitação, Newton certamente unificou o céu e a terra, mostrando que o movimento dos astros se rege necessariamente pelo mesmo princípio que o movimento dos corpos terrestres. Porém, para Hegel, essa unificação na lei padece de inefetividade; ela não é ainda uma verdadeira síntese dos opostos, uma reconciliação entre extremos, porque o objeto da lei está dentro da própria lei. A lei se reconcilia consigo mesma, permanecendo estranha à efetividade. Assim, se os movimentos de todos os corpos são enunciados pela lei da gravitação, "a atração universal diz apenas que tudo tem uma diferença constante com Outro. O entendimento pensa ter aí descoberto uma lei universal, que exprime a universal efetividade como tal. Mas, na verdade, só encontrou o conceito da lei mesma." ${ }^{30}$ A lei de máxima abrangência é justamente aquela que não enuncia a ocorrência de nenhum fenômeno em particular. Ela descreve a totalidade de casos possíveis mediante a supressão de todos os casos singulares. Diz de todos porque não diz de nenhum. E assim o entendimento fracassa em exprimir a unidade do diverso por meio da lei, mas ao fazê-lo ele expõe a fórmula geral da lei, que é a unilateralidade do universal. A lei da gravitação, a lei das leis, define a própria lei geral do entendimento, cujo regime se instaura em todas as esferas da vida como uma lógica da inversão. Pois, para salvar a validade do seu conhecimento, o entendimento precisa sacrificar a essência do fenômeno, preservando o padrão de racionalidade do aparato científico e convencendo-se, por fim, de que não há

\footnotetext{
${ }^{29}$ Id., Fenomenologia do Espírito, III, "Força e Entendimento; Fenômeno e mundo supra-sensível”, p. 120 (121).

${ }^{30}$ Ibid., p. 120 (121).
} 
verdade além da representação: cria para si um mundo invertido, onde o efetivo é o inessencial e a ausência universal de efetividade está posta como fundamento. A inversão do mundo é a experiência de passagem da realidade à racionalidade mediante a negação simples. Decerto, para o pensamento conceitual essência também se manifesta pela inversão em uma aparência contrária. "Porém, se for erigida em lei essa inversão - que é representada no castigo do crime - será também de novo apenas a lei de um mundo que tem como sua contrapartida um mundo supra-sensível invertido, no qual se honra o que no outro se despreza, e onde é ignomínia o que no primeiro é honra. O castigo, que segundo a lei do primeiro mundo desonra e destrói o homem, transmuda-se, em seu mundo invertido, no perdão que salvaguarda sua essência e o leva à honra." ${ }^{31}$ A lei não comporta a diferença existente entre as suas representações e o ser efetivo; logo, se a inversão absoluta de uma essência em seu contrário for reconhecida na forma de lei, o contrário reconhecido será apenas a fixação na lei de uma abstração da essência como ser essencial. Por isso, a inversão na lei constitui a legalidade de um mundo que se duplica em um outro mundo abstrato. Neste mundo, cindido em dois mundos opostos e sobrepostos, cada oposto é para si a totalidade, mas em si é apenas uma totalidade oposta a outra. A legalidade possui uma vigência transcendental, que rege somente representações, enquanto a efetividade só é regida mediante sua transposição à contrariedade. Assim, segundo Hegel, "numa outra esfera," 32 a lei institui a pena pública sobre a vingança privada. Para a individualidade ultrajada, o castigo do crime consiste na vingança de infligir um mal que degrada efetivamente a essência do seu ofensor. Porém, representado pela lei, o mesmo ato vale universalmente como um bem que, do contrário, a restaura.

Sabemos que Kant tomava a filosofia da natureza de Newton por modelo de ciência, e que a crítica kantiana almeja estabelecer para o conhecimento em geral o que Newton estabeleceu para o movimento dos corpos. "A matemática e a física”, diz Kant, "são os dois conhecimentos teóricos da razão que devem determinar seus objetos a priori, a primeira de modo inteiramente puro, a segunda de modo pelo menos em parte puro, mas tomando ainda como medida outras fontes de conhecimento que não as da razão. A matemática, desde os tempos mais remotos alcançados pela história da razão humana, já com o admirável povo

\footnotetext{
${ }^{31}$ Ibid., p. 126 (129).

32 Ibid., p. 126 (129).
} 
grego, encetou o caminho seguro de uma ciência." ${ }^{33}$ Também Descartes, antes de Kant, pensava a matemática como matriz da cientificidade: tanto que o Discurso do Método, após a famosa fundamentação metafísica do saber, inclui outros três ensaios em que o método recebe sua aplicação científica - Da Dioptria, Dos Meteoros e Da Geometria. Neste último, Descartes nos dá a conhecer sua maior contribuição para a matemática, traduzindo a geometria espacial dos antigos para uma notação algébrica moderna. Não obstante, para Hegel, "o movimento do saber [matemático] passa por sobre a superfície, não toca a Coisa mesma, não toca a essência ou o conceito, e portanto não é um conceber. A matéria, onde a matemática preserva um tesouro gratificante de verdades, é o espaço e o uno. O espaço é o ser-aí, no qual o conceito inscreve suas diferenças, como num elemento vazio e morto, no qual as diferenças são igualmente imóveis e sem vida. O efetivo não é algo espacial, como é tratado na matemática; com tal inefetividade, como são as coisas da matemática, não se ocupa nem a intuição sensível concreta nem a filosofia. Por conseguinte, nesse elemento inefetivo, só há também um Verdadeiro inefetivo; isto é, proposições mortas e rígidas." ${ }^{34}$ Com isso Hegel não pretende descartar a necessidade ou a utilidade do conhecimento matemático, mas apenas distingui-lo do saber absoluto. O saber absoluto reduz à possibilidade a posse do conhecimento, inclusive do conhecimento matemático, mas segundo um esforço mais amplo de totalização, e que deve ser promovido na direção contrária: ao invés de se purgar das diferenças, em busca de uma identidade com a razão abstrata, deve antes introduzir as diferenças vivas na reflexão. De modo que se há de compreender a ciência anterior como restrita ao seu âmbito. Segundo Hegel, o entendimento científico - a ciência nos limites do entendimento - serve somente às necessidades da vida cotidiana. "A consciência na vida cotidiana tem, em geral, por seu conteúdo, conhecimentos, experiências, sensações de coisas concretas, e também pensamentos, princípios - o que vale para ela como um dado ou então como ser ou essência fixos e estáveis." 35 Surge aqui uma das mais instigantes conseqüências da propositura hegeliana: a advertência contra a opacidade que faz do cotidiano uma experiência de indeterminação. Nas atividades prosaicas, no comércio da vida, a consciência raciocina apenas dentro dos limites do entendimento; isto é, fabrica representações e aplica

\footnotetext{
${ }^{33}$ KANT, I., Crítica da Razão Pura, Prefácio à Segunda Edição, p. 36.

${ }^{34}$ HEGEL. G. W., Fenomenologia do Espírito, Prefácio, p. 51 (44).

${ }^{35}$ Ibid., 54 (48).
} 
conhecimentos bem estabelecidos para resolver problemas imediatos. A proliferação de representações eficazes acaba por envolver a consciência em uma cortina de aparências que a deixa cega para o verdadeiro. Ela pensa que compreende os conceitos abstratos que utiliza e os assume como verdades últimas. "Eis um esforço que poderia ser poupado: produzir verdades últimas desse tipo, porque desde muito se encontram, por exemplo, no catecismo, nos provérbios populares etc." ${ }^{36}$ Entregue ao senso comum, a consciência não pode se realizar como sujeito. Cabe à reflexão apresentar a experiência da consciência como determinada para emancipá-la desta metafísica do cotidiano em que se encontra absorvida. Mas é somente a própria consciência quem pode empreender essa reflexão. "A consciência, ao abrir caminho rumo à sua verdadeira existência, vai atingir um ponto onde se despojará de sua aparência: a de estar presa a algo estranho, que é só para ela, e que é como um outro. Aqui a aparência se torna igual à essência, de modo que sua exposição coincide exatamente com esse ponto da ciência autêntica do espírito. E, finalmente, ao apreender sua verdadeira essência, a consciência mesma designará a natureza do próprio saber absoluto."37

Em suma, o passo além a que procede a filosofia especulativa reside na maneira como o sujeito toma parte na reflexão. Ao invés de a verdade se realizar parcialmente como certeza, a certeza se realiza integralmente como verdade. "Nesse movimento subverte-se até aquele sujeito inerte: penetra nas diferenças e no conteúdo, e em vez de ficar frente a frente com a determinidade, antes a constitui: isto é, constitui o conteúdo diferenciado como também o seu movimento." ${ }^{38}$ Para Kant, a síntese do conhecimento cabe exclusivamente ao entendimento. A faculdade de conhecer não se regula pelo objeto, mas o objeto se regula pela faculdade de conhecer. O Eu é somente a sede racional de categorias apriorísticas que organizam os dados empíricos recolhidos pela intuição. "No pensamento conceitual, o sujeito comporta-se de outra maneira. Enquanto o conceito é o próprio Si do objeto, que se apresenta como seu vir-a-ser, não é um sujeito inerte que sustenha imóvel os acidentes; mas é o conceito que se move, e que retoma em si suas determinações." ${ }^{39}$ Isso significa que, na reflexão, a atuação do conceito não se dá com a imposição, sobre o objeto,

\footnotetext{
${ }^{36}$ Ibid., p. 68 (64).

${ }^{37}$ Id., Fenomenologia do Espírito, Introdução, p. 82 (80-81).

${ }^{38}$ Id., Fenomenologia do Espírito, Prefácio, p. 62-63 (57).

${ }^{39}$ Ibid., p. 62 (57).
} 
de formas racionais para si incondicionadas. O objeto carrega em si mesmo o conceito que aparece para a consciência.

$\mathrm{O}$ entendimento propugna que o sujeito constitui para si um objeto, mas nega que o objeto também constitui para si um sujeito. Então a relação com um objeto determinado parece limitar o saber do sujeito porque esse saber é representado como uma potência diversa da sua relação efetiva. Porém, se a reflexão integrar em si também o modo como o próprio sujeito é posto na relação, então o seu saber do objeto resta reduzido a um conteúdo absolutamente determinado para o pensar, e a relação consumada deixa de figurar como limite. A espinha dorsal da reflexão, portanto, só pode ser a seguinte pergunta: quais os processos e condições objetivas em que se constitui o sujeito de um saber determinado? Sua resposta requer uma reordenação da própria noção de sujeito, a ser compreendido não mais como mera faculdade cognoscitiva, ou como Eu abstrato; mas, sobretudo, como um sujeito da experiência, para qual o próprio conhecer se revela uma forma de agir. Este é um dos mais belos movimentos da Fenomenologia do Espírito e, sem dúvida, não há exagero em aclamá-lo como a grande contribuição de Hegel para a filosofia.

Importa notar que a propositura geral de exprimir a substância como sujeito toca o repto concernente a cada problema teórico específico. Uma vez que "o pensar unifica consigo o ser da substância e compreende a imediatez e o intuir como pensar, o problema é saber se esse intuir intelectual não é uma recaída na simplicidade inerte; se não apresenta, de maneira inefetiva, a efetividade mesma." ${ }^{, 40} \mathrm{O}$ espírito é a consubstanciação para o sujeito da sua fusão com a substância - é a intuição na qual o pensar finalmente satisfaz a exigência de apresentar a efetividade enquanto tal, isto é, de pôr para si, de uma maneira efetiva, a efetividade mesma. Este pensar já não se separa da realidade como consciência dela: ele é o próprio devir real, para qual o em-si da consciência constitui a efetividade. “(...) a essência em-si-e-para-si-essente, que ao mesmo tempo é para si efetiva como consciência, e que se representa a si mesma para si, é o espírito."41 No espírito, "que é a existência,"42 a substância se torna sujeito não no oposto estranho de si mesma, mas na própria efetividade de um agir universal, que é o produto das obras de todos e de cada um. "Só o espiritual é o efetivo: é a essência ou o em-si-essente: o relacionado consigo e o

\footnotetext{
${ }^{40}$ Ibid., p. 35 (23).

${ }^{41}$ Id., Fenomenologia do Espírito, VI, “O Espírito”, p. 304 (324).

${ }^{42}$ Ibid., p. 305 (325).
} 
determinado; o ser-outro e o ser-para-si; e o que nessa determinidade ou em seu ser-forade-si permanece em si mesmo - enfim, o [ser] espiritual é em-si-e-para-si." ${ }^{43}$ Não há nada mais emblemático do hegelianismo do que a síntese máxima das determinações de um ser tomar a aparência de uma categoria abstrata.

$\beta)$ O lugar da individualidade na fenomenologia

Em diversas passagens do Prefácio, Hegel adverte que os esclarecimentos prefaciais não servem para demonstrar a sua concepção; que só o próprio percurso fenomenológico está apto a fazê-lo, e que, por conseguinte, só contra ele seria lícito dirigir uma refutação. A recorrente remissão de Hegel ao corpo probante da Fenomenologia do Espírito, notável não apenas no Prefácio, mas também em muitos outros momentos de suas obras posteriores, coloca em relevo a estrita especificidade da gênese fenomenológica do conceito. Bem se vê ser essa gênese bastante diversa de uma fundamentação no sentido tradicional - e justamente por isso ela tem de ser necessariamente apresentada na forma de uma fenomenologia: não se pode executá-la como uma demonstração lógica das condições de possibilidade do pensar. ${ }^{44}$ Trata-se, inclusive, da crítica a esse procedimento de deduzir os pressupostos apodícticos do uso do entendimento. Mas como procede, então, a própria fenomenologia?

O que esta "Fenomenologia do Espírito" apresenta é o vir-a-ser da ciência em geral ou do saber. O saber, como é inicialmente - ou o espírito imediato - é algo carente-de-espírito: a

\footnotetext{
${ }^{43}$ Id., Fenomenologia do Espírito, Prefácio, p. 39 (28).

${ }^{44}$ No início da segunda parte da Ciência da Lógica, Hegel retoma o problema implicado em expor a natureza do conceito à parte da gênese do conceito, e esclarece como uma tal exposição, quando necessária, deve ser entendida:
}

O que há pouco foi apresentado tem de ser considerado como o conceito do conceito. Se o mesmo pode parecer se afastar daquilo que se compreende de outro modo por conceito, então poderia ser exigido que fosse demonstrado como o mesmo, que aqui resultou como o conceito, está contido em outras representações e esclarecimentos. Por um lado, porém, a questão não pode consistir numa confirmação fundamentada por meio da autoridade da compreensão comum; na ciência do conceito seu conteúdo e determinação podem somente ser confirmados por meio da dedução imanente que contém sua gênese e que já reside atrás de nós. Por outro lado, certamente o conceito aqui deduzido tem de ser reconhecido em si no que de outro modo é apresentado como o conceito do conceito. [HEGEL, G. W. Ciência da Lógica, parte II: 'A lógica subjetiva ou a doutrina do conceito. Sobre o conceito.' Tradução de Marco Aurélio Werle.] 
consciência sensível. Para tornar-se saber autêntico, ou produzir o elemento da ciência que é seu conceito puro, o saber tem de se esfalfar através de um longo caminho. Esse vir-a-ser, como será apresentado em seu conteúdo e nas figuras que nele se mostram, não será o que obviamente [zunächst] se espera de uma introdução da consciência não-científica à ciência; e também será algo diverso da fundamentação da ciência. ${ }^{45}$

A fenomenologia é a ciência dos fenômenos que aparecem para a consciência. Enquanto tal, ela não pode repetir aquilo "que sucede na demonstração ordinária: os fundamentos que [esta] utiliza precisam por sua vez de uma fundamentação, e assim por diante até o infinito."46 Pois "essa forma de fundar e de condicionar pertence àquele demonstrar que é diferente do movimento dialético; portanto, pertence ao conhecer exterior." ${ }^{47}$ Adiante examinaremos a peculiaridade desta dialética que Hegel considera verdadeiramente apta a fundar e a condicionar. Ela se mostra ao longo de toda a fenomenologia, que nos propõe apresentar o processo constitutivo do saber, isto é, o percurso que leva da forma mais baixa de consciência até a ciência, ou da certeza sensível ao saber absoluto - a primeira e a última das famosas figuras fenomenológicas. Cada figura adota uma conduta em resposta a determinada necessidade surgida na relação da consciência com a efetividade, cuja exposição mobiliza uma série de problemas bastante específicos para a filosofia hegeliana. Recapitular a gênese do conceito, do início ao fim da fenomenologia, é um trabalho árduo que o próprio Hegel prefere evitar no Prefácio e que aqui nos levaria apenas à confecção de um selvagem resumo. Convém prevenir, contudo, contra o mal-entendido habitual de se compreender a busca fenomenológica pelo saber absoluto como uma pretensão de esquadrinhar toda a extensão da realidade até exauri-la definitivamente para a razão. Como vimos, o motivo central da Fenomenologia do Espírito, discutido e rediscutido pari passu à sucessão de figuras, diz respeito ao pleno reconhecimento da negatividade enquanto modo de operação da consciência: “(...) deve-se manter longe a representação sensível da consolidação das diferenças num distinto elemento do subsistir."48 A reconstrução lógica do princípio de identidade enquanto contradição visa a encontrar uma forma racional de ponderar o indeterminado, e não suprimir a existência da indeterminação. Aliás, abolir para si a alteridade da essência é

\footnotetext{
${ }^{45}$ Id., Fenomenologia do Espírito, Prefácio, p. 40-41 (31).

${ }^{46}$ Ibid., p. 66 (61).

${ }^{47}$ Ibid., p. 66 (61).

${ }^{48}$ Id., Fenomenologia do Espírito, III, "Força e Entendimento; Fenômeno e mundo supra-sensível”, p. 128 (130).
} 
precisamente o que Hegel censura ao puro entendimento, à representação, à lei, ao desejo, à dominação senhorial, ao estado de direito, ao terror revolucionário etc. Em todas as figuras da fenomenologia, a exigência colocada para a razão consiste justamente em se tornar capaz de absorver o Outro sem o anular - isto é: em conservar a diferença na identidade. Eis o sentido da verdadeira infinitude. Donde resulta incongruente calcar a figura do saber absoluto em uma completa transparência da apercepção cognoscitiva, que seria atingida no esgotamento final da coisa para o saber; ou ainda, noutro plano, inscrever Hegel no rol de uma inabalável metafísica moderna, e situar a noção hegeliana de ciência no apogeu da escalada de uma razão que se perfaz por meio da exclusão de tudo o que se opõe a ela.

\title{
$\gamma)$ Fenomenologia X Fundamentação
}

\begin{abstract}
A tarefa de conduzir o indivíduo, desde seu estado inculto até o saber, devia ser entendida em seu sentido universal, e tinha de considerar o indivíduo universal, o espírito consciente-de-si na sua formação cultural. No que toca à relação entre os dois indivíduos, cada momento do indivíduo universal se mostra conforme o modo como obtém sua forma concreta e sua configuração própria. O indivíduo particular é o espírito incompleto, uma figura concreta: uma só determinidade predomina em todo o seu ser-aí, enquanto outras determinidades ali só ocorrem como traços rasurados. No espírito que está mais alto que um outro, o ser-aí concreto inferior está rebaixado a um momento invisível: o que era antes a Coisa mesma, agora é um traço apenas: sua figura está velada, tornou-se um simples sombreado. ${ }^{49}$
\end{abstract}

Até então a fenomenologia havia sido definida antes em vista de seus fins do que de seus meios. A propositura de exprimir a substância como sujeito era justificada como enunciação do resultado da filosofia especulativa, cuja fenomenologia apresenta a escalada do saber humano rumo ao "elemento da ciência". Agora, finalmente, ficamos a par do que efetivamente se ocupa esta apresentação. O percurso constitutivo do saber autêntico não pode ser senão o processo de formação cultural do indivíduo. É sobre o desenvolvimento do indivíduo, portanto, que a fenomenologia pretende fundar a cientificidade.

Há de se insistir para que não passe despercebida a envergadura da reordenação teorética contida nessa inflexão. É precisamente neste ponto que a fenomenologia hegeliana se contrapõe à essência de uma fundamentação convencional e nos oferece positivamente um novo modo de pensar. Já aludimos a que o cogito cartesiano inaugurava um regime de pensamento baseado na identidade interior do sujeito consigo mesmo. O reconhecimento da

\footnotetext{
${ }^{49}$ Id., Fenomenologia do Espírito, Prefácio, p. 41 (31).
} 
convergência entre ser e pensar em uma certeza de si imediata é a pedra de toque de que Hegel se serve para condensar a modernidade filosófica na categoria do entendimento.

Segundo o célebre argumento de Descartes, embora o sujeito possa se enganar quanto ao conhecimento da coisa sob sua intuição, havemos de observar que, contudo, essa mesma intuição lhe dá ensejo de chegar racionalmente a um outro conhecimento cuja verdade não é passível de dúvida: o conhecimento da existência deste próprio conhecer subjetivo; ou seja, o conhecimento de que se o sujeito conhece, não importa o quê, então deve haver, por conseguinte, um sujeito existente que se põe a conhecer. "Por exemplo, se me persuado de que há uma terra, porque a toco ou vejo, mais razões tenho para estar persuadido de que o meu pensamento é ou existe - porque pode suceder que eu pense tocar a terra, embora não haja talvez nenhuma terra no mundo - e de que não seja possível que eu, isto é, minha alma, não seja nada enquanto tem este pensamento. Podemos concluir o mesmo de todas as outras coisas que nos vêm ao pensamento, isto é, que nós existimos porque as pensamos, embora elas talvez sejam falsas ou não tenham nenhuma existência." A intuição não fornece nenhum conhecimento seguro a respeito das coisas empíricas, porém permite concluir pela existência do próprio sujeito pensante, que assim se concebe como uma consciência pura, independente de qualquer objeto. Este sujeito faz experiência de si na efetividade de sua intuição singular, mas só tem certeza de ser como incondicionado; ele assevera sua existência como sendo a necessidade de um pensar universal sem conteúdo. Essa existência do sujeito enquanto pensamento é considerada verdadeira por derivar de uma ilação apodíctica absolutamente imune às incertezas da consciência sensível. "Com efeito, temos tanta repugnância em conceber que aquele que pensa não existe verdadeiramente ao mesmo tempo em que pensa, que, apesar das mais extravagantes suposições [sobre a verdade ou a existência das coisas], não poderíamos nos impedir de acreditar que a conclusão penso, logo existo não seja verdadeira e, por conseguinte, a mais certa que se apresenta àquele que conduz seus pensamentos por ordem." ${ }^{, 51}$ Uma vez assegurada a verdade do cogito, Descartes o promove a primeiro princípio de todo o saber. Mas quem é "aquele" que de fato conclui existir? Seria o mesmo que se pôs, de início, a duvidar? A dificuldade legada à posteridade está em compreender a

\footnotetext{
${ }^{50}$ DESCARTES, René. Princípios da Filosofia, § 11, p. 31.

${ }^{51}$ Ibid., $§ 7$, p. 29.
} 
natureza deste Eu que se dilui no Nós do discurso cartesiano. A rigor, o eu singular não chega a ajuizar, ele próprio, sua existência: o exercício da dúvida somente o leva a conceber o cogito. O ser pensante que perpetra o ajuizamento concebido é um eu universal retirado do mundo sensível. Em Descartes, a sobreposição obscura desse sujeito abstrato ao sujeito empírico se patenteia quando ambos são definidos mediante uma disjunção abrupta: “Aquele que pretende duvidar de tudo não pode, no entanto, duvidar que existe enquanto duvida, e que aquele que assim raciocina, não podendo duvidar de si próprio e, todavia, duvidando de todo o resto, não é aquilo a que chamamos corpo, mas sim aquilo a que chamamos alma ou pensamento. ${ }^{, 52}$ Tudo se passa como se o corpo só pudesse descobrir a sua alma fora de si mesmo, ou como se raciocinasse com uma subjetividade que não lhe pertence; ou ainda, como se a sua dúvida cessasse por saber que um outro é capaz de elucidá-la - um outro a que chamamos alma ou pensamento, e que não tem efetividade como ser singular. Na aurora da modernidade, o sujeito só consegue afirmar sua existência fazendo abstração de si mesmo. Sua lógica, portanto, padece de um defeito. Reformá-la é o cerne da filosofia hegeliana.

Descartes aceita pacificamente que o cogito seja um princípio metafísico, isto é, que sua verdade se propugne acima do mundo sensível - e não é por outro motivo, afinal, que ele o considera apto a servir de fundamento para o saber. A proposta clássica de fundamentação alcança plena consolidação com Kant, quando se enfrenta a necessidade de esclarecer a relação entre o sujeito transcendental e o entendimento. Depois de Descartes, as descobertas e aplicações da mecânica evidenciaram a crescente importância da experiência para o progresso das ciências. Kant percebeu a incongruência de se recusar à sensibilidade uma função constitutiva da certeza. Assim, na Crítica da Razão Pura, de 1781, ele delimitou o âmbito de validade do saber à unidade sintética da apercepção - o ato cognitivo que determina o conhecimento surgido na experiência como "um composto daquilo que recebemos por impressões e daquilo que a nossa própria faculdade de conhecimento, apenas provocada por impressões sensíveis, fornece de si mesma." ${ }^{, 53}$ Perante a perplexidade suscitada pelo conflito de representações, que induzia Descartes a abandonar a experiência para meditar em busca de um saber interior, isento da interferência sensível,

\footnotetext{
${ }^{52}$ Ibid., Prefácio, p. 19.

${ }^{53}$ KANT, I., Crítica da Razão Pura, Introdução, p. 53.
} 
Kant, por sua vez, procura um modo de ater a consciência à coisa percebida, e não apenas pensada. "Há dois troncos do conhecimento humano que talvez brotem de uma raiz comum, mas desconhecida de nós, a saber, a sensibilidade e o entendimento: pela primeira os objetos são-nos dados, mas pelo segundo são pensados." ${ }^{54}$ A intuição sensível capta o múltiplo sob a forma espaço-temporal de um objeto para o sujeito, a cujo entendimento cabe processar uma síntese desse objeto com as suas representações racionais. "Falando de modo geral, entendimento é a faculdade de conhecimentos. Estes consistem na referência determinada de representações dadas a um objeto. Objeto, porém, é aquilo em cujo conceito é reunido o múltiplo de uma intuição dada." ${ }^{, 5}$ Assim, em relação a Descartes, o conhecimento do objeto é visto não mais como o simples abalo causado pela coisa na subjetividade, mas como produto de uma faculdade ativa, que funde o empírico e o racional em um terceiro elemento sintético. "Por síntese entendo, no sentido mais amplo, a ação de acrescentar diversas representações umas às outras e de conceber a sua multiplicidade num conhecimento." ${ }^{56}$ Mediante a síntese do conhecimento na unidade da apercepção, o sujeito chega a introduzir a diferença no conteúdo da certeza - eis a novidade da filosofia kantiana, que abre as portas da ciência para uma vasta ordem de fenômenos empíricos e problemas práticos.

Entretanto, a conciliação proposta não se dá assim tão facilmente. Ainda paira uma dúvida sobre a verdade deste conhecimento gerado na apercepção sintética: pois, afinal, o ato cognitivo não pode ser senão uma certeza particular. "Uma pessoa liga uma certa palavra a uma coisa; uma outra pessoa, a uma outra coisa - a unidade da consciência naquilo que é empírico, no tocante ao que é dado, não é válida necessária e universalmente." ${ }^{, 57}$ A atribuição de representação ao objeto pode variar conforme cada entendimento, na medida em que as apercepções se distinguem, por conteúdos diversos, de uma faculdade de conhecer comum. De modo que Kant se reencontra com a precariedade do saber finito bem ali onde o entendimento havia sintetizado o absoluto. "Depende de circunstâncias ou de condições empíricas se posso ser empiricamente consciente do múltiplo como simultâneo ou sucessivo. Eis por que a unidade empírica da consciência,

\footnotetext{
${ }^{54}$ Ibid., p. 67.

${ }^{55}$ Id. , Crítica da Razão Pura, Analítica Transcendental, § 16, p. 123-124.

${ }^{56}$ Ibid., $\$ 10$, p. 107.

${ }^{57}$ Ibid., §18, p. 125.
} 
mediante a associação de representações, concerne ela mesma a um fenômeno e é inteiramente contingente. ${ }^{, 58}$ Mas como garantir, então, a objetividade de um conhecimento que se manifesta ao sabor de contingências, e no interior de uma consciência sensível? Claro está, para Kant, que o fundamento de um conhecimento não pode pertencer à verdade de seu próprio objeto. Se a unidade sintética da consciência se desfaz nas contingências da apercepção, então o fenômeno que se manifesta para a consciência empírica precisa ser objeto de uma outra forma de apercepção cujo conteúdo não varie circunstancialmente. “A unidade transcendental da apercepção é aquela pela qual todo o múltiplo dado numa intuição é reunido num conceito do objeto. Em vista disso, denomina-se objetiva e tem que ser distinguida da unidade subjetiva da consciência, que é uma determinação do sentido interno, mediante o qual aquele múltiplo da intuição é dado empiricamente para tal ligação." ${ }^{59}$ Ao lado da unidade empírica da consciência, ou da unidade da diferença, Kant dispõe uma outra unidade idêntica a si mesma, que surge como nada mais do que a necessidade lógica de pressupor a existência de uma faculdade de pensar. "O eu penso tem que poder acompanhar todas as minhas representações; pois, do contrário, seria representado em mim algo que não poderia de modo algum ser pensado, o que equivale a dizer que a representação seria impossível ou, pelo menos para mim, não seria nada." ${ }^{, 60} \mathrm{~A}$ representação eu penso desponta dentre todas as demais representações porque nela nenhum conteúdo exterior ao sujeito é atribuído ao pensar. Em regra, as representações estão vinculadas ao conceito de um objeto. "Esta representação, porém, é um ato de espontaneidade, isto é, não pode ser considerada pertencente à sensibilidade. Chamo-a apercepção pura para distingui-la da empírica, ou ainda, apercepção originária, por ser aquela autoconsciência que ao produzir a representação $e u$ penso, que tem que poder acompanhar todas as demais representações e é una e idêntica em toda consciência, não pode jamais ser acompanhada por nenhuma outra. Denomino também sua unidade de unidade transcendental da autoconsciência, para designar a possibilidade do conhecimento a priori a partir dela." ${ }^{61}$ E assim se reabre, no entendimento, a oposição entre ser e pensar. A síntese sucumbe ao imperativo analítico de que dependia. Kant separa o ato cognitivo da

\footnotetext{
${ }^{58}$ Ibid., $§ 18$, p. 125.

${ }^{59}$ Ibid., $\S 18$, p. 125 .

${ }^{60}$ Ibid., $\$ 16$, p. 121.

${ }^{61}$ Ibid., $\$ 16$, p. 121.
} 
potência intelectiva, e erige a simples identidade dessa consciência-de-si em pressuposto de toda percepção sensível, tal qual na fundamentação cartesiana. Uma vez que a consciência particular é empiricamente determinada, também a Kant resta assumir a consciência-de-si da consciência particular como o elemento universal a cuja presença necessária se limita a objetividade do conhecimento. Pois se o conceito determinado na unidade subjetiva da consciência não pode aspirar à validade universal, por estar eivado de uma oposição ao múltiplo, não haveríamos de concluir que só se pode considerar objetiva a consciência da ausência do conteúdo percebido? Neste caso não seria possível ter um juízo seguro sobre as coisas exteriores, e Kant se contentaria em proclamar a vacuidade do conhecimento baseado na experiência, para situar a ciência no campo exclusivo das demonstrações lógicas e dedutivas. Com efeito, supomo-lo prestes a sacar da algibeira um tratado de geometria quando ele reitera que, "portanto, o primeiro conhecimento puro do entendimento, sobre o qual se funda todo o seu uso restante e que ao mesmo tempo é inteiramente independente de todas as condições da intuição sensível, é o princípio da unidade sintética originária da apercepção." ${ }^{\text {"62 }}$ Mas Kant sinceramente não pretende se entregar aos braços da metafísica por força desta conclusão. Vejamos aonde o conduzirá a obrigação de sustentá-la. Na medida em que esse princípio originário serve para operar a associação de dados empíricos e representações racionais em uma unidade de consciência objetiva, na qual se pode enfim considerar que "essas representações estão ligadas no objeto, isto é, sem distinção do estado do sujeito, e não apenas juntas na percepção;"63 na medida em que, portanto, a consciência-de-si e a consciência empírica estabelecem entre si uma unidade, e que algum conteúdo da percepção passa de algum modo para a unidade objetiva da consciência, pois, do contrário, não haveria conhecimento de nenhum objeto, então começam, aqui, os impasses que marcam decisivamente o desfecho e a recepção da filosofia kantiana.

- Paralogismo na Crítica da Razão Pura: o estatuto problemático do sujeito transcendental

\footnotetext{
${ }^{62}$ Ibid., $§ 17$, p. 124.

${ }^{63}$ Ibid. $§ 19$, p. 126. (Destaque meu em itálico)
} 
Naturalmente, poder-se-ia questionar se não haveria uma contradição em ser a proposição fundamental da apercepção pura um princípio operador de sínteses. Não, previne Kant, a unidade sintética originária não opera nenhuma síntese em si mesma. "Embora torne a unidade sintética condição de todo pensamento, esta última proposição é ela mesma, como ficou dito, analítica. Com efeito, não afirma senão que, em qualquer intuição dada, todas as minhas representações têm que se submeter à condição unicamente sob a qual posso atribuí-las, como representações minhas, ao próprio eu idêntico e, por conseguinte, enquanto ligadas sinteticamente numa apercepção, enfeixá-las mediante a expressão universal eu penso." ${ }^{, 64}$ Sem postular uma consciência originária, para qual o conjunto de representações do entendimento esteja desligado de qualquer objeto, ou, noutras palavras, sem imputar o ato cognitivo ao encargo de uma potência pensante alheia ao ato, definida como a decomposição analítica da unidade sintética, o sujeito não poderia sequer se distinguir do conteúdo das suas várias apercepções empíricas; ou seja, "somente pelo fato de eu poder conceber numa consciência o múltiplo das representações denomino todas de minhas representações, pois do contrário teria um eu mesmo tão multicolor e diverso quanto tenho representações das quais sou consciente." ${ }^{65}$ Com que, por fim, para salvar o negativo do esgotamento no positivo, a própria condição de sujeito é reafirmada como uma subjetividade transcendental que restringe a verdade do outro à certeza de si mesma. O "princípio supremo de todo o uso do entendimento"66 acaba por fundamentar apenas um entendimento sem uso, uma vez que "essa proposição fundamental não é contudo um princípio para todo o entendimento em geral, mas somente para aquele ao qual, mediante sua apercepção pura na representação $e u$ sou, ainda não foi dado absolutamente nada de múltiplo." ${ }^{67}$ Trata-se da faculdade pertencente a um sujeito universal desprovido de

\footnotetext{
${ }^{64}$ Ibid., § 17, p. 124. Sobre a distinção kantiana entre juízos sintéticos e analíticos, vale citar:
}

Em todos os juízos em que for pensada a relação de um sujeito com o predicado (se considero apenas os juízos afirmativos, pois a aplicação dos negativos é posteriormente fácil), essa relação é possível de dois modos. Ou o predicado B pertence ao sujeito A como algo contido (ocultamente) nesse conceito A, ou B jaz completamente fora do conceito A, embora esteja em conexão com o mesmo. No primeiro caso denomino o juízo analítico, no outro sintético. Juízos analíticos (os afirmativos) são, portanto, aqueles em que a conexão do predicado com o sujeito for pensada por identidade; aqueles, porém, em que essa conexão for pensada sem identidade, devem denominar-se juízos sintéticos. (KANT, I., Crítica da Razão Pura, Introdução, p. 58)

${ }^{65}$ Id., Crítica da Razão Pura, Analítica Transcendental, § 17, p. 124.

${ }^{66}$ Ibid., $\$ 17$, p. 123.

${ }^{67}$ Ibid., $§ 17$, p. 124. 
relação com o mundo sensível. A este seria dada a única certeza absoluta. Em contrapartida à dedução de um eu abstrato que permanece em eterna identidade consigo, também o lado da efetividade resulta enunciado como um predicado homogêneo, um vasto desconhecido que não tem substância para a reflexão, muito embora lhe sirva de premissa material. "O conceito de substância refere-se sempre a intuições, que em mim não podem ser senão sensíveis e que, por conseguinte, se encontram totalmente fora do campo do entendimento e do seu pensamento." ${ }^{68}$ Assoma o esquema geral da filosofia kantiana, em que o ideal exclui de si o real, e tanto o infinito quanto o empírico são proclamados amorfos, tal qual Hegel já acusava pelo menos desde Fé e Saber: "O idealismo crítico [de Kant] consiste assim em nada mais senão no saber formal de que o sujeito e as coisas, ou o não-Eu, existem cada um por si - o Eu do "eu penso" e a coisa em si - não como se cada um fosse substância, um como coisa anímica, o outro como coisa objetiva, mas o Eu do "eu penso", como sujeito, é absoluto, assim como a coisa que se encontra para além dele, ambos sem determinações segundo categorias",69.

Kant dedica as páginas mais polêmicas da Razão Pura a gerenciar conseqüências de sua doutrina dos fenômenos. Considera que a má compreensão do juízo eu penso poderia suscitar "a única pedra de escândalo contra a nossa inteira Crítica."70 Lidamos, portanto, com um tema delicado. Há uma certa periclitância da razão envolvida em aceitar que o enunciado de um juízo sintético, asseverado por um sujeito empírico, possa valer como proposição analítica. Isso ocorre porque o juízo eu penso "serve para distinguir duas espécies de objetos extraídos da natureza da nossa capacidade de representação. Eu, como pensante, sou um objeto do sentido interno e denomino-me alma. Aquilo que é um objeto dos sentidos externos denomina-se corpo." ${ }^{71} \mathrm{Na}$ estrutura do juízo, a consciência do objeto da intuição é determinada pelas categorias do entendimento. Quando o objeto da intuição é o próprio sujeito, segundo Kant, não se deve confundir o juízo sobre a alma com o juízo sobre o corpo, ainda que ambos comportem o mesmo enunciado. A consciência empírica do corpo possui como conteúdo a síntese de um eu figurado; a unidade do juízo eu penso, por sua vez, é uma pura consciência-de-si requerida como pressuposto da consciência

\footnotetext{
${ }^{68}$ Id., Crítica da Razão Pura. Capítulo Primeiro do Livro Segundo da Dialética Transcendental, p. 261.

${ }^{69}$ HEGEL, G. W. Fé e Saber, p. 44. (Acréscimo meu entre colchetes)

${ }^{70}$ KANT, I., op. cit, p., 261.

${ }^{71}$ Ibid., p. 257.
} 
empírica de qualquer objeto - e, neste caso, o objeto do juízo, a alma, "consiste não na consciência do Si determinante, mas somente na consciência do Si determinável". ${ }^{72}$ Por isso, a existência do sujeito implicado no juízo eu penso não deve ser tomada como referida ao eu ajuizador, quem quer que o seja, sob pena de se incorrer na classe de inferências sofísticas que Kant denomina paralogismo. O paralogismo é um erro de raciocínio que ocorre quando se atribui determinidade ao conceito transcendental de sujeito; isto é, quando se liga um objeto à representação de um sujeito ao qual não foi dado nada de múltiplo pela experiência. De modo que "a minha existência não pode ser encarada como inferida da proposição eu penso, tal como julgou Descartes (...), mas é idêntica com tal proposição."73 Assim, se Descartes pretendia nada menos do que descobrir, segundo nos diz, os "princípios a partir dos quais se pode deduzir o conhecimento de todas as outras coisas que existem no mundo" ${ }^{\text {74 }}$, sendo o cogito o primeiro deles, do qual se deduz, ao cabo, tudo mais - agora vemos que, para Kant, uma vez suprida a necessidade de deduzir um princípio fundamental, já não é mais lícito prosseguir à dedução de nenhum outro conhecimento a partir dele. O conhecimento, para Kant, precisa ser produzido a cada caso, e não pode jamais prescindir da sensibilidade, pois sua síntese requer a diferença fornecida pela intuição. Onde cessa a experiência, ali começa o uso ilegítimo da razão. A tênue experiência do sujeito consigo mesmo, ou o seu sentido interno, o exame da própria interioridade, encontra-se precisamente nesse ponto de transição, em que o sujeito empírico até possui alguma intuição, mas que não pode, contudo, ser licitamente ajuizada. Portanto, não apenas não se deve confundir a proposição analítica eu penso com um juízo sintético sobre o corpo, mas mesmo o fato de que o entendimento a constitua como um juízo que toma a alma por objeto não deve ser admitido pela crítica como um conhecimento válido desse objeto, "e a conclusão é que não podemos conhecer de maneira alguma seja o que for sobre a natureza da nossa alma, relativamente à possibilidade da sua existência separada em geral." ${ }^{, 75}$ Kant fulmina a passagem do cogito ao ergo sum. Mas o que significa, então, o enunciado do princípio originário? "O eu penso, como já se disse, é uma proposição

\footnotetext{
${ }^{72}$ Ibid., p. 260.

${ }^{73}$ Ibid., p. 267, nota de rodapé

${ }^{74}$ DESCARTES, René. Princípios da Filosofia, p. 20.

${ }^{75}$ KANT, I., Crítica da Razão Pura. Capítulo Primeiro do Livro Segundo da Dialética Transcendental, p. 266.
} 
empírica e contém em si a proposição eu existo." ${ }^{76}$ Do ponto de vista de um entendimento esclarecido, capaz de contornar o paralogismo, como considerar este Eu que se manifesta em uma proposição na qual a sua própria existência está logicamente implicada? "A proposição: eu penso, todavia, é tomada aqui só problematicamente, não enquanto ela possa conter uma percepção de uma existência (o cartesiano cogito ergo sum), mas segundo a sua simples possibilidade, para ver que propriedades possam decorrer dessa proposição tão simples ao sujeito dela (quer ele exista ou não)."77 Ao esvaziar a proposição fundamental de todo e qualquer conteúdo, insistindo, por um lado, em reafirmá-la como veículo do uso prático do entendimento, apesar de não se imiscuir em nenhum conhecimento aplicado; e convertendo-a, por outro, em mote para denúncia do paralogismo e demarcação crítica dos limites cognoscitivos da razão, Kant entabula um excurso que o levará finalmente a definir o estatuto ontológico das necessidades apodícticas.

Nada se sabe sobre o sujeito representado na consciência pura do juízo, a não ser que sua presença é necessária no juízo a cada intuição. "Mediante este eu, ou ele, aquilo (a coisa) que pensa, não é representado mais do que um sujeito transcendental dos pensamentos $=\mathrm{X}$, que é conhecido somente pelos pensamentos que são seus predicados, e do qual, separadamente, não podemos ter o mínimo conceito." ${ }^{, 78}$ Os predicados dos juízos determinam os modos de ser do sujeito empírico, mas nunca do sujeito transcendental. A consciência-de-si ou o eu idêntico não se deixa afetar nas apercepções, embora sempre as acompanhe, porque "todos os modi da autoconsciência do pensamento ainda não são em si conceitos intelectuais de objetos (categorias), mas simples funções lógicas que não dão a conhecer ao pensamento absolutamente nenhum objeto - por conseguinte, tampouco a mim mesmo enquanto objeto." ${ }^{, 79}$ A representação da existência do eu, retida na consciência-desi, resulta de uma consecução formal da lógica da razão, não sintetiza nenhuma premissa empírica, e por isso não fornece nenhuma realidade. Que o entendimento precise recorrer à função dessa representação para operar juízos sintéticos, que só possa pensá-la mediante a união de um predicado a um sujeito, que preencha arbitrariamente essa relação com objetos impróprios, e que dela extraia, por fim, um par de falsas inferências, dando ora existência à

\footnotetext{
${ }^{76}$ Ibid., p. 267, nota de rodapé.

${ }^{77}$ Ibid., p. 259.

${ }^{78}$ Ibid., p. 258.

${ }^{79}$ Ibid., p. 260.
} 
alma, e ora corpo ao Eu - eis por que o cogito se abeira, para Kant, do precipício do paralogismo, onde a razão perde a terra, e não convém ter esperança de voar. Na dilucidação problemática do cogito, para defender que o ajuizamento da certeza de si de um sujeito empírico é uma proposição analítica, Kant se vê obrigado a cassar a dignidade ontológica das condições de possibilidade da finitude. Uma vez determinada, a unidade sintética da consciência - que deve reter o saber absoluto (o conhecimento categorizado) oscila entre a apercepção pura e a apercepção empírica sem nunca conseguir se acomodar, até que reste fixada como objetiva por força não da funcionalidade cognitiva, mas da retificação crítica que descarta as premissas constitutivas da subjetividade percipiente. Por conseguinte, só se admite como real o campo sob influência imediata da consciência particular, e o caráter lógico da função desempenhada no entendimento pelos pressupostos da apercepção os caracteriza como um ideal incógnito sem consistência de ser. Assim, paradoxalmente, Kant condiciona a consciência-de-si à experiência e a experiência à consciência-de-si ao mesmo tempo em que instaura um conceito de objetividade enquanto campo incondicionado. As funções lógicas não pertencem à realidade, e por isso o eu apodíctico pode condicionar necessariamente os juízos sem precisar existir. Se o entendimento teima em inferir a sua existência, há de se compreender que "a existência, neste caso, não é ainda uma categoria - a qual não possui referência a um objeto dado indeterminadamente, mas só a um objeto do qual se tenha um conceito e sobre o qual se quer saber se é posto também fora deste conceito ou não." ${ }^{80}$ A questão de saber se o objeto conceituado remete ou não a uma essência extra-fenomênica é deixada em aberto. Não obstante, esse arranjo permite a Kant reler o cogito como uma fórmula carente de cunho categorial, a despeito de conter uma assertiva ontológica. "Em todos os juízos sou sempre o sujeito determinante da relação que constitui o juízo. Que, entretanto, eu, que penso, sempre tenha que valer no pensamento como sujeito $[=\mathrm{X}]$ e $[$ também] como algo que não pode ser considerado simplesmente como predicado inerente ao pensamento, é uma proposição apodíctica e mesmo idêntica; mas ela não significa que eu, enquanto objeto, seja um ente subsistente para mim mesmo, ou uma substância." ${ }^{\circledR 1}$ Embora o eu encontre determinação no objeto do juízo, sua consciência-de-si não encontra a substância de si

\footnotetext{
${ }^{80}$ Ibid., p. 267, nota de rodapé.

${ }^{81}$ Ibid., p. 260 (Acréscimos meus entre colchetes).
} 
nesse mesmo objeto. Por isso, na representação da consciência-de-si, o predicado ergo sum não põe o sujeito como um ser objetivo. A categoria da substância, "mediante a qual é representada uma coisa em si mesma, ${ }^{, 82}$ não está aplicada nem a um eu singular e nem a um eu transcendental. De modo que, em primeiro lugar, a substância do eu afirmada como predicado da proposição analítica não pode "significar a identidade da pessoa pela qual é entendida a consciência da identidade da substância própria de cada um, como um ser pensante, em toda a variação dos estados." ${ }^{83}$ Em seus diversos estados, a substância da pessoa pensante, ou de qualquer eu singular, só poderia ser efetivamente fornecida por um estudo empírico; "para demonstrar tal identidade, não serviria para nada a simples análise da proposição eu penso, mas se requereriam diversos juízos sintéticos fundados sobre a intuição dada." ${ }^{84}$ Em segundo lugar, tampouco pode significar que pensar seja condição suficiente para existir, pois "mediante tal proposição não sei absolutamente se esta consciência de mim mesmo é possível sem coisas fora de mim pelas quais me são dadas as representações e, portanto, se posso existir simplesmente como ente pensante (sem ser homem). ${ }^{85}$ Que não se considere o cogito, portanto, como demonstração da necessidade de haver uma certeza absoluta enquanto faculdade de um eu transcendental subsistente por si mesmo. Surge aqui a face herética, o ganho de excelência moderna da filosofia kantiana: o homem determinado como um ser para si, e o próprio ser determinado como humano; e a potência pensante reconhecida apenas na posse de seus direitos, isto é, apenas como ato do entendimento, afora qual não há nada a se saber, ainda que tanto se especule. A crítica suspende o juízo sobre supostas entidades ideais. No caso do juízo eu penso, o entendimento gira em falso e cai no vazio, ligando um sujeito transcendental a um predicado insubstancial. "Conseqüentemente, através da análise da consciência de mim mesmo, no pensamento em geral, não se ganha nada com respeito ao conhecimento de mim mesmo como objeto. A exposição lógica do pensamento em geral é tomada falsamente por uma determinação metafísica do objeto." ${ }^{, 86}$ E Kant encerra o deslinde do paralogismo satisfeito por ter provado, quanto à pura consciência-de-si, "que o conceito de uma coisa que pode existir para si mesma como sujeito e não como simples predicado não envolve

\footnotetext{
${ }^{82}$ Ibid., p. 258.

${ }^{83}$ Ibid., p. 261.

${ }^{84}$ Ibid., p. 261.

${ }^{85}$ Ibid., p. 261.

${ }^{86}$ Ibid., p. 261.
} 
ainda nenhuma realidade objetiva; isto é, que não se pode saber se a tal conceito pode ser atribuído qualquer objeto, já que não se vislumbra a possibilidade de um tal modo de existir." 87

- Paradoxo crítico e resolução fichteana: estatuto categorial do sujeito transcendental

Em um espectro mais amplo, que abrange a denúncia do paralogismo, toda a Crítica da Razão Pura se destina a coibir que a razão seja empregada como faculdade em si mesma prática, pretensamente capaz de extrair determinações metafísicas de seu próprio interior, por meio de uma atividade tão-somente intelectual. Não se há de estranhar, portanto, que a necessidade de postular a representação da consciência-de-si como advento da razão pura adquira as proporções de um grande embaraço. Sabemos que a maior parte do capítulo sobre o paralogismo foi acrescentada ao magnum opus por ocasião de sua segunda edição, de 1787, quando Kant, já em vista de repercussões, inseriu no texto uma série de declarações de propósito, com intenção de "prevenir o mal-entendido a que está facilmente exposta a doutrina da nossa auto-intuição como fenômenos." ${ }^{88}$ Esforço que se traduz na reiterada advertência para "que não se faça nenhum outro uso das categorias (como da de substância) a não ser o uso empírico" ${ }^{89}$ - e que revela, mais do que a preocupação com ilações alheias, uma tentativa de harmonizar o iniludível paradoxo a que o leitor se sente conduzido. De fato, Kant parece chegar a uma conclusão que não pode ser admitida para que se chegue a ela. Conclui que a consciência-de-si só pode ser considerada real se constitui condição de um juízo sintético; porém, para que ela constituísse condição de um juízo sintético, não se podia considerá-la real.

Detenhamo-nos no corolário da filosofia kantiana. A síntese de duas instâncias indeterminadas produz a realidade como modo de representação da consciência. Como se há de compreendê-lo? Seu paradoxo consiste em a realidade pressupor uma não-realidade como condição. Ora, como seria possível estar-se condicionado por algo que não existe, ou como algo inexistente poderia atuar como condição? A intervenção de Kant na segunda edição tendeu a ponderar pela conclusão de que a consciência viveria confinada em um

\footnotetext{
${ }^{87}$ Ibid., p. 263.

${ }^{88}$ Ibid., p. 272.

${ }^{89}$ Ibid., p. 264.
} 
mundo próprio - uma realidade particular, demarcada na substância até o limite do alcance das formas e categorias cognoscitivas. $\mathrm{O}$ indeterminado não penetraria na apercepção, as funções lógicas do $\mathrm{Eu}$ e do múltiplo seriam recursos de raciocínio sem referência a nenhuma verdade, e a crítica permitiria convencionar universalmente que a unidade absoluta da consciência-de-si logra ter por conteúdo apenas o conhecimento dessa circunscrição finita.

A tese de que a consciência-de-si se descobre isolada das massas amorfas recebeu a pecha de dogmatismo, na medida em que, neste caso, a ciência estaria submetida à autoridade de pressupostos arbitrários, e rebaixada ao ofício de registrar aparições de procedência inquestionável. Nesta conjectura de uma consciência-de-si ilhada no incógnito, ademais, persiste a dificuldade de que ela se saberia afetada por condições exteriores que, contudo, não reconhece como reais. Por isso ganhou força - e não pelo número de adeptos - o ambicioso plano de restauração do espírito da crítica. Para Fichte, seu maior expoente, admitir a possibilidade de massas a sediar as causas dos fenômenos seria sacrificar o principal resultado da filosofia kantiana: o de conceber a objetividade como subjetivamente determinada. "Para mim, não se trata - para dizer claramente o que penso - de justificar ou de completar os conceitos filosóficos correntes, quer sejam anti-kantianos ou kantianos. Para mim, trata-se de os eliminar totalmente e de transformar por completo o modo de pensar sobre estes pontos de reflexão, de maneira que com toda a seriedade, e não apenas por assim dizer, o objeto seja posto e determinado pela faculdade de conhecer, e não a faculdade de conhecer pelo objeto." ${ }^{90}$ No esteio desta concepção, que radicaliza Kant, o simulacro fenomênico seria a manifestação da oposição entre o Eu e o múltiplo - e não apenas da oposição entre a consciência e o objeto. Por conseguinte, a forçosa circunscrição do horizonte humano à finitude - que redunda na representação da essência absoluta como um vazio - teria o efeito prático de abolir as massas, ou de suprimir o estatuto de indeterminação. O corolário kantiano teria o sentido de instaurar a realidade da consciência-de-si enquanto totalidade do ser. Em vez de um mundo particular, a consciência-de-si teria para si um campo de experiência irrestrito e universal.

Bem se vê que nos encontramos perante desdobramentos opostos, cada qual a ressaltar uma das duas vertentes indubitavelmente presentes nos escritos de Kant: por um

\footnotetext{
${ }^{90}$ FICHTE, J. G., Primeira Introdução à Doutrina da Ciência, p. 314.
} 
lado, a absoluta diversidade entre o ideal e o real; por outro, a absoluta identidade entre ambos. Já em 1795, nas Cartas Filosóficas sobre o Dogmatismo e o Criticismo, o jovem Schelling assinalara haver um conflito entre dois pontos de vista antagônicos no interior da filosofia kantiana. Mas foi Hegel, ao constatar que "a efetividade finita pode, portanto, a rigor, ser tomada como melhor convenha," 91 quem primeiro assumiu a presença desta ambigüidade como um fato consumado, abortando a via de tentar solucionar a essência do iluminismo em um princípio único, autêntico e definitivo.

Fichte adotara essa via com máxima energia, e jamais renunciou a ela. Malgrado reiterasse incansavelmente "que o meu sistema não é outro senão o kantiano," 92 considerava ociosa a iniciativa de apenas "comentar Kant, sem nunca encontrar o específico de seu sistema, porque não o encontra ninguém que não abra o seu próprio caminho na descoberta do mesmo." 93 Mais de quinze anos após a primeira edição da Crítica da Razão Pura, Fichte avalia que "Kant permaneceu até agora um livro fechado, se excetuarmos uma achega recente, que mais adiante mencionarei, e o que se leu nele é precisamente aquilo que não está de acordo com ele, e que ele pretendia refutar." ${ }^{94}$ Observa ainda que, com efeito, "pode parecer a outros pretensioso e mesquinho quando alguém aparece sozinho a dizer: até este momento, dentre a multidão de sábios de nomeada que consagraram o seu tempo e as suas aptidões à interpretação de um determinado livro, não houve um único que não compreendesse este livro de forma completamente errada; nele encontraram precisamente o sistema contrário ao sistema que é exposto; dogmatismo em vez de idealismo transcendental: mas eu sou o único que o compreende corretamente. No entanto, uma tal pretensão poderia realmente ser apenas aparente; pois é possível ter esperança de que posteriormente também outros venham a compreender o livro deste modo, e que aquilo que até agora era único deixe de o ser. Não quero aqui apresentar outras

\footnotetext{
${ }^{91}$ HEGEL, G.W. Fenomenologia do Espírito, VI, B, 2-a, “A luta do iluminismo contra a superstição”, p. 387 (415).

${ }^{92}$ FICHTE, J., op. cit., p. 314.

${ }^{93}$ Id., Recensão de Enesidemo, p. 311-312.

${ }^{94}$ Id., Primeira Introdução à Doutrina da Ciência, p. 314. A "achega recente" que Ficthe mencionará adiante é a obra de Jacob Sigismund BECK, publicada em 1796 - depois, portanto, da primeira Doutrina da Ciência - com o título mui elucidativo de Einzig möglicher Standpunkt, aus Welchem die kritische Philosophie beurteilt werden muss ( $O$ único ponto de vista possível do qual se deve julgar a filosofia crítica).
} 
razões pelas quais não será se considerar pretensioso o ousar contradizer todos os kantianos."95

A esperança de Fichte estava destinada a encontrar alento no consentimento de Hegel. "A filosofia fichteana é o aperfeiçoamento [Vollendung] da filosofia kantiana,"96 define ele nas famosas Preleções sobre a História da Filosofia. Naturalmente, a positividade deste aperfeiçoamento contém um elemento negativo. Talvez a contragosto, Fichte iniciou a revisão dos pressupostos da filosofia kantiana ao propugnar que a inteligibilidade desta obriga a conceder o estatuto de determinante para as condições de possibilidade da consciência-de-si ativa. "Segundo Kant, toda a consciência é apenas condicionada pela autoconsciência, ou seja, o conteúdo daquela pode ser fundamentado por qualquer coisa exterior à consciência-de-si; ora, as conseqüências desta fundamentação só não podem contradizer as condições da consciência em si; só não podem suprimir a possibilidade desta, mas também não precisam necessariamente de proceder dela."97 De fato, vimos que, para Kant, o Eu = X se limita a condicionar a consciência-de-si particular, ou o juízo sintético, e cumpre esta função desde que permaneça sempre idêntico, alheio à determinidade; por conseguinte, o ajuizamento não pode nem assentar o condicionante $\mathrm{e}$ nem inferir dele nenhuma determinação. Isso dá margem a se conjecturar que não haveria nada de universal no eu singular. Sem o concurso da razão comum, porém, os objetos da experiência não seriam categorizados. Portanto, a finitude não pode prescindir de universalidade na unidade absoluta da consciência-de-si independente. Fichte pretende sanar qualquer possibilidade de equívoco quanto à compreensão deste aspecto da filosofia kantiana, esclarecendo que "em conformidade com a Doutrina da Ciência" - sua principal obra, de 1794 - "toda a consciência é determinada pela autoconsciência, isto é, tudo o que se passa na consciência é fundamentado, dado, produzido pelas condições da consciênciade-si; e não existe realmente nenhum fundamento dela para além da consciência-de-si. Tenho de salientar que, no nosso caso, a determinidade provém de forma imediata da condicionalidade e que, portanto, a diferença referida [entre ambas], neste caso, não existe nem tem significado." 98

\footnotetext{
${ }^{95}$ Id., Segunda Introdução à Doutrina da Ciência, p. 346.

${ }^{96}$ HEGEL, Vorlesungen über die Geschichte der Philosophie III, p. 387.

${ }^{97}$ FICHTE, op. cit., p. 344.

${ }^{98}$ Ibid., p. 344 (Acréscimos meus entre colchetes).
} 
Fichte admite que esta propositura marca, em relação a Kant, senão um ponto de divergência, ao menos um ponto de definição. "Confesso que não consigo conceber como se pode compreender um só princípio em Kant, e relacioná-lo com outros princípios, sem partir deste pressuposto." 99 O pressuposto implícito na filosofia kantiana seria, noutras palavras, o de que a objetividade está necessariamente submetida, em toda sua extensão, às condições de possibilidade do pensar. "Assim o objeto, enquanto dado, também só é pensado". ${ }^{100} \mathrm{O}$ predicado é indissociável do sujeito, o Não-Eu é em si categorizado pelo Eu. A existência empírica e a existência transcendental coincidem no ser. Para a consciência finita, a essência absoluta decerto aparece incógnita, mas precisamente porque a consciência a determina na representação como um vazio, e não porque ela esteja impossibilitada de representar enquanto tal uma remota coisa-em-si que a afetaria de fora do seu campo de experiência. Caso contrário, "Kant seria um tagarela tão mesquinho quanto esses tais kantianos." ${ }^{101}$ Trata-se então de reexpor a filosofia kantiana em face do seu todo, para lhe dar inequívoca unidade sistêmica. E para "encontrar o sistema do modo permanente de ação do espírito humano," 102 segundo Fichte, "toda a filosofia deve ser referida a um princípio único." $103 \mathrm{Na}$ busca pelo princípio supremo do uso do entendimento, Kant descobrira o cogito e nele se deteve. Mas se o cogito tem em si uma consciência pura que permanece para si sem unidade com a diferença; isto é, se, no cogito, o Eu não tem a sua essência no si da consciência-de-si, isso não pode significar que o objeto da consciência seja categorizado sem o concurso do Eu, pois, neste caso, não haveria objeto algum, mas apenas uma coisa desprovida de fundamento e abandonada à própria sorte. Por conseguinte, o conceito de sujeito sem objeto deve ser entendido como uma categoria pura, e o objeto da consciência-de-si, como um puro predicado do Eu. O Eu - a categoria apodíctica de substância - assoma como este princípio único que permite referir à determinidade absoluta da consciência-de-si na finitude. Kant não chegou propriamente a explicitá-lo. "Se, recuando ainda mais no caminho que ele com tanta glória abriu, viesse a descobrir-se no futuro, por exemplo, que o imediatamente mais certo - eu sou, só é válido também para o Eu; que todo o Não-Eu só é para o Eu; que ele [o eu sou] recebe todas as

\footnotetext{
${ }^{99}$ Ibid., p. 342.

${ }^{100}$ Ibid., p. 352.

${ }^{101}$ Ibid., p. 343.

${ }^{102}$ Id., Recensão de Enesidemo, p. 312.

103 Ibid., p. 312.
} 
determinações deste ser a priori apenas através da sua relação com um Eu; mas que todas estas determinações, na medida em que seu conhecimento é de fato possível a priori, se tornam absolutamente necessárias através da mera condição da relação de um Não-Eu com um Eu em geral - resultaria daqui que uma coisa-em-si, na medida em que deve ser um Não-Eu que não está em oposição a um Eu, se contradiz a si mesma, e que a coisa efetivamente em si é constituída tal como tem de ser pensada por todo o ser que pensa segundo o princípio da identidade e da contradição, e que, por conseqüência, a verdade lógica é também real para toda a inteligência pensável pela inteligência finita, e que não há nenhuma outra a não ser esta." ${ }^{104}$ Assim, para Fichte, o princípio supremo não é exatamente o eu penso, mas o Eu do juízo eu penso. As condições de possibilidade do sujeito devem ser consideradas existentes e necessárias independentemente de viabilizarem a consecução deste ou daquele juízo empírico em particular. Além da explosiva conclusão final pela inexistência de uma mente sobre-humana, compete ainda observar, nesse excerto de admirável concisão, que o programa filosófico fichteano termina acenando para uma ontologização da lógica que será depois reformulada e executada por Hegel em sua monumental Ciência da Lógica de 1812.

\section{${ }^{-}$Hegel e a refutação do conceito transcendental de sujeito}

Se, por um lado, Hegel deu o peso de sua anuência à opinião de que Fichte levou a cabo "uma apresentação mais conseqüente da filosofia kantiana,"105 jamais ignorou, por outro, que essa maior perfeição implicava reforço da abstração do sujeito na figura de um Eu absoluto. No âmbito da filosofia moral, a rigidez com que Fichte separa o Eu puro do Eu empírico nos mostra de modo particularmente claro que a reivindicação de estatuto categorial para o Eu em nada dispensa de uma defesa radical da identidade simples da certeza de si em sua relação com a alteridade: "O homem deve continuamente estar de acordo consigo mesmo; jamais deve contradizer-se. A saber, o Eu puro nunca pode estar em contradição consigo mesmo, pois não há nele diferença alguma, mas é sempre um e o mesmo. O Eu empírico, porém, determinado e determinável pelas coisas exteriores, pode

\footnotetext{
${ }^{104}$ Ibid., p. 312 (Acréscimos meus entre colchetes).

${ }^{105}$ HEGEL, G. W. F., op. cit., p. 388.
} 
contradizer-se - e sempre que se contradiz é um sinal seguro de que ele não é determinado segundo a forma do Eu puro, por si mesmo, mas mediante as coisas exteriores. E não deve ser assim; pois o homem é o seu próprio fim; deve determinar-se a si mesmo e nunca se deixar determinar por algo estranho; deve ser o que é, porque o quer ser e o deve querer ser. O Eu empírico deve dispor-se de modo como eternamente poderia estar disposto."106 Embora conceba a oposição entre Eu e Não-Eu como pertencente à determinidade, Fichte ainda a considera uma oposição essencial, ou seja, uma mediação independente, interposta entre dois pólos que se privam ou de si na relação com o outro ou do outro na relação consigo. Que essa modalidade de oposição agora se instaure sem cindir a totalidade unificada do ser se exprime pelo fato de que a identidade do sujeito consegue se preservar da negação porque a essência do sujeito é determinada como um dever. A existência do dever é um ser em desacordo com a essência do próprio ser. A determinidade se torna um estado de perpétua contrariedade do ser em relação a si. "A vocação última de todos os seres racionais e finitos é, por conseguinte, a unidade absoluta, a identidade incessante, a consonância racional consigo mesmo. Esta identidade absoluta é a forma do Eu puro e a sua única forma verdadeira; ou antes, a expressão desta forma reconhece-se na cogitabilidade da identidade." ${ }^{107} \mathrm{O}$ dever é a finalidade potencial inscrita na necessidade do ato, de modo que, para o homem, determinar-se significa perseguir, na exterioridade, o objeto de sua intuição interior. A percepção de si na meditação continua a fornecer o princípio formal de identidade que orienta a ação do espírito. Porém, mais do que um começo seguro para o conhecimento teórico, o cogito funciona agora como a essência de um imperativo que, deduzido da razão, a consciência empírica enuncia como fim de toda a sua atividade prática. $\mathrm{O}$ homem acede à razão pela vontade consciente, avocando ao seu próprio dever o direito universal. Neste iluminismo revolucionário, entretanto, uma vez que a consciênciade-si se atualiza analiticamente, o fim jamais encontra realização nos meios como um destino consumado. A ação consiste em perseguir continuamente um dever em si mesmo oposto ao ser. O dever é o que não é. Devo ser porque não sou. E assim sempre. Por conseguinte, para Fichte, os seres racionais finitos nunca chegam a suprir a exigência essencial de sua vocação. "O conceito do homem é um conceito ideal, porque o fim do

\footnotetext{
${ }^{106}$ Id., Lições sobre a vocação do sábio, p. 25.

${ }^{107}$ Ibid., p. 25.
} 
homem, enquanto tal, é inatingível."108 A impossibilidade de instauração prática do conceito é pensada aqui como impossibilidade de restauração a posteriori da identidade original da consciência-de-si.

Hegel observa que a identidade abstrata do conceito de substância - a idealidade do sujeito - é um resultado incontornável e denotativo do iluminismo. "Ao conceber em geral toda a determinidade, isto é, todo o conteúdo e sua implementação, dessa maneira, como uma finitude, como essência e representação humana, a essência absoluta torna-se para ele um vazio, a que não se podem atribuir determinações nem predicados." ${ }^{109}$ E neste ponto estão de acordo tanto a vertente do dogmatismo quanto a do idealismo transcendental. Hegel ainda explica por que o iluminismo se empenha com tamanha obstinação em apartar o ideal da inteligência finita. "Um tal conúbio seria, em si, condenável; pois é justamente nele que foram engendrados os monstros da superstição. A razão, a pura inteligência, certamente não é vazia, ela mesma, porque o seu negativo é para ela, e é o seu conteúdo, mas ela é rica, embora somente em singularidade e limitação. Não permitir que nada semelhante aconteça à essência absoluta, nem que lhe seja atribuído, é a conduta circunspecta da inteligência que sabe pôr em seu lugar a si mesma e a sua riqueza de finitude, e tratar dignamente o absoluto." 110 Vimos que uma das superstições contra qual luta o iluminismo é a crença na existência de uma alma incorpórea. É bem verdade que Kant procura não propriamente negar essa existência em si, mas denunciar a crença nela como fruto de um raciocínio falacioso, o paralogismo, que cria a ilusão de uma determinação metafísica. Sabendo que o além só é passível de concepção racional na figura amorfa do incógnito, o entendimento esclarecido não se deixa assombrar por extravagantes devaneios da imaginação. Para Hegel, porém, a grande contradição do iluminismo se manifesta justamente ao explicar a entidade ideal como uma espécie de aberração representativa, indigna de crédito por ter nascido de uma predicação indevida. "A pura inteligência enreda-se nessa contradição, porque se empenha na luta supondo combater algo outro." ${ }^{111}$ Ao combater a crença na verdade das falsas representações, o iluminismo cai em contradição porque concebe como produtos da consciência as mesmas superstições que ele

\footnotetext{
${ }^{108}$ Ibid., p. 37.

${ }^{109}$ HEGEL, G. W. Fenomenologia do Espírito, VI, B, 2-a, “A luta do iluminismo contra a superstição”, p. 385 (413).

${ }^{110}$ Ibid., 385 (413).

${ }^{111}$ Ibid., p. 377 (404).
} 
pretende expulsar do campo da razão. "Assim, o que a pura inteligência enuncia como o seu Outro - como erro ou mentira - não pode ser outra coisa que ela mesma: só pode condenar o que ela é." "112 Pois não há aparência que se desfaça da própria essência. Mesmo as ilusões têm de estar radicadas. Entretanto, a teoria dos erros da razão cancela a objetividade de certa ordem de juízos sob alegação de que eles seriam manifestações insubstanciais do entendimento. No caso do paralogismo, Kant acusa um erro na certeza de si, que consistiria em confundir a auto-intuição do sujeito empírico com a consciência-de-si do Eu. "Porém, no saber da essência, em que a consciência tem a certeza imediata de si mesma, está descartado completamente o pensamento do engano."113 Hegel acredita que nem mesmo por equívoco se possa gerar uma certeza de si desprovida de objeto. A consciência-de-si expressa no cogito deve necessariamente conter a percepção de uma existência. Se, no cogito, a certeza de si é enunciada como certeza de si de um outro, então este outro só pode estar na própria certeza de si, embora o iluminismo tente a todo custo distingui-lo dela. "O Iluminismo enuncia imediatamente como [sendo] o mais próprio da consciência o que enuncia como algo a ela estranho. Como pode, assim, falar de impostura e de ilusão? (...) Como pode dar-se impostura e ilusão ali, onde a consciência tem imediatamente em sua verdade a certeza de si mesma? Onde ela possui a si mesma no seu objeto, porque nele tanto se encontra como se produz? A diferença não existe mais, nem mesmo nas palavras." ${ }^{114}$ Importa notar que o ponto de chegada de Hegel não é e nem poderia ser a defesa da cognoscibilidade da alma enquanto objeto da intuição. Não se trata de dar substância aos objetos de fé, de provar a existência de determinações metafísicas. Do contrário, Hegel contesta a hipótese de erro na certeza de si justamente porque o cancelamento da objetividade da falsa representação a erige em essência autônoma, uma vez que a consecução formal do juízo defeituoso opera um conceito transcendental de sujeito que seria inatingível para a consciência ou alheio à razão. Assim, o que de fato se delineia nesta passagem é uma refutação da afirmação kantiana de "que o conceito de uma coisa que pode existir para si mesma como sujeito e não como simples predicado não

\footnotetext{
112 Ibid., p. 377 (404).

${ }^{113}$ Ibid., p. 381 (407).

${ }^{114}$ Ibid., p. 380 (406).
} 
envolve ainda nenhuma realidade objetiva." ${ }^{115}$ Hegel não quer predicar licitamente o eu idêntico, mas sim mostrar que a realidade objetiva necessariamente envolvida na determinação do ideal não pode ser fornecida pelo ato cognitivo de categorizar dados da sensibilidade. A verdade do conceito transcendental de sujeito não cabe na unidade sintética da apercepção.

Eis que reatamos o fio das soluções oferecidas pela filosofia hegeliana. Hegel está empenhado em um duplo movimento que perpassa toda a Fenomenologia do Espírito. Em primeiro lugar, trata-se de expor o esgotamento das tentativas de salvar a identidade simples em quaisquer dos modos de exteriorização da subjetividade, e conceber um modo afirmativo de determinação por meio da negação, sem o qual a negação será sofrida desde sempre em vão, por um sujeito incapaz de dominá-la. Um passo essencial para tanto é dado quando surge "uma inteligência que reconhece a absoluta negação de si mesma como sua própria efetividade". ${ }^{116}$ Este reconhecimento precisa ser aprofundado. Por isso Hegel não admite artifícios verbais que restabeleçam uma oposição essencial entre a consciência-de-si e a alteridade. "Quando a consciência-de-si é o objeto, é tanto Eu quanto objeto."117

Em segundo lugar, e simultaneamente, trata-se de explicitar a verdade daquilo que se esconde por detrás do 'Eu'. O iluminismo defendia que a essência absoluta pode ser objeto apenas de fé, de crença, mas não de representação racional. "Mas a essência absoluta da fé essencialmente não é a essência abstrata que se encontre além da consciência crente; é, sim, o espírito da comunidade, é a unidade da essência abstrata da consciência-de-si."118 E assim Hegel nos introduz ao seu melhor. Pois agora ficamos a saber que aquela figura misteriosa, indevassável, que se subtraía da faculdade de conhecer, e que todavia concedia a bênção momentânea da razão universal sobre a subjetividade da consciência-de-si ativa e efetiva - aquilo que Kant espremia no conceito cego de um Eu transcendental, incógnito, apodíctico, e cuja presença funcional no entendimento ele justificara como sendo um "ato de espontaneidade" no $\S 16$ da Analítica Transcendental - eis que agora ficamos a saber que isto é, na verdade, o "espírito da comunidade": noção que implica, mais do que uma

\footnotetext{
${ }^{115}$ KANT, I., Crítica da Razão Pura, Capítulo Primeiro do Livro Segundo da Dialética Transcendental, p. 263.

${ }^{116}$ HEGEL, G. W. Fenomenologia do Espírito, VI, B, 2-a, “A luta do iluminismo contra a superstição”, p. 378 (405).

${ }_{117}^{1}$ Id., Fenomenologia do Espírito, IV, “A verdade da certeza de si mesmo”, p. 142 (145).

${ }^{118}$ Id. Fenomenologia do Espírito, VI, B, 2-a, "A luta do iluminismo contra a superstição”, p. 379 (407).
} 
consciência de todos, uma comunidade de todas as consciências. A ascendência da comunidade sobre a consciência está condicionada pela atuação da consciência sobre a comunidade. "Que a essência absoluta seja o espírito da comunidade, nisso está implícito que o agir da comunidade é um momento essencial: ele só é mediante o produzir da consciência - ou melhor, não é sem ser produzido pela consciência. Com efeito, por essencial que seja o produzir, é igualmente essencial que não seja o fundamento único da essência, mas apenas um momento. A essência é ao mesmo tempo em si e para si mesma." 119 A essência absoluta não é para si apenas em si, nos confins, no ilimitado; ela não é, na verdade, uma essência absoluta, mas é essência também no seu ser-para-si. Em cada momento da substância está presente a substância como um todo. O Em-si está no objeto da consciência-de-si; logo, a consciência-de-si é também consciência-do-Si e consciência-de-si do Si. Mas se distinguimos o ser em momentos de uma totalidade que se engendra por meio da reflexão, então já aludimos ao próprio conceito de espírito. "O espírito é a substância e a essência universal, igual a si mesma e permanente: o inabalável e irredutível fundamento e ponto de partida do agir de todos, seu fim e sua meta, como [também] o Em-si pensado de toda a consciência-de-si." ${ }^{120} \mathrm{O}$ circuito de toda posição teleológica, seja cognitiva ou intencional, tem ambas as pontas condicionadas pelo espírito. E toda ação consciente perpetrada sobre a substância contribui para animá-la a um movimento próprio. "Essa substância é igualmente a obra universal que, mediante o agir de todos e de cada um, se engendra como sua unidade e igualdade, pois ela é o ser-para-si, o $\mathrm{Si}$, o agir. (...) Nela cada um executa sua própria obra, despedaça o ser universal e dele toma para si sua parte. Tal dissolução e singularização da essência é precisamente o momento do agir e do Si de todos. É o movimento e a alma da substância, e a essência universal efetuada. Ora, justamente por isso - porque é o ser dissolvido no $\mathrm{Si}$ - não é a essência morta, mas a essência efetiva e viva." ${ }^{121}$ Morta era a representação da essência absoluta. Mas saber que todo objeto da consciência é uma essência espiritual ainda não elimina o problema de como exprimir, em uma forma pensável, o conteúdo destas singularidades intrincadas em infinitas relações com o todo. A receita hegeliana para o pensamento científico consistirá em reduzir o processo de diferenciação da substância a

\footnotetext{
${ }^{119}$ Ibid., p. 380 (406).

${ }^{120}$ Id., Fenomenologia do Espírito, VI -“O Espírito”, p. 305 (325).

${ }^{121}$ Ibid., p. 305 (325).
} 
uma lógica racional que execute em potência este movimento ativo de recuperar, descobrir e ampliar os momentos que constituem a vida da verdade. Daí então a necessidade de refutar a transcendentalidade do conceito ou do ideal. Hegel procura um modo de pensar um universal determinado - não como um objeto, um predicado - mas como convergência de causas e acidentes com que a substância se oferece à própria reflexão. Surge aqui a diferença entre o espírito e o conceito transcendental de sujeito. Em Kant, o conceito é conceito de um objeto da consciência na unidade da apercepção. A unidade está cindida em opostos, mas não se consegue conceber que os opostos tenham efetividade fora da oposição, ou que, na oposição, estejam indeterminados por um momento. (O idealismo transcendental e o dogmatismo assumem respectivamente cada qual a defesa de uma alternativa contra a outra.) Em Hegel, a substância se dá efetividade na medida em que essa oposição é superada pelo conceito. "O Si só é efetivo para si como suprassumido [aufgehoben]. Portanto, o Si não constitui para ele a unidade da consciência de si mesmo e do objeto; mas o objeto é para o Si o seu negativo. Assim, mediante o Si enquanto alma, a substância é plasmada [ausgebildet] em seus momentos, de tal modo que um oposto vivifica o outro; e cada um, através de sua alienação, dá subsistência ao outro, e dele igualmente a recebe." 122

E assim Hegel põe um ponto final no pesado esforço crítico de distinguir um eu puro de um eu empírico na estrutura do juízo. Nenhuma representação consegue exprimir a verdade do sujeito, isto é, a substância. Só uma fenomenologia poderá parir o espírito. Longe de ser o saber mais seguro de todos, a consciência de si é antes um dos mais precários, pois nela todo o ser é depositado a cargo de uma subjetividade ingênua, despreparada para comportá-lo - tanto que o separa de si. Um sujeito que pretenda conhecer a profusão de circunstâncias determinantes de si próprio precisa elaborar toda uma reflexão que requer elementos da experiência e que jamais poderia ser substituída de início pela intuição imediata. Por isso, a certeza de si não proporciona um fundamento sólido para a ciência, tampouco uma boa porta de entrada para a filosofia. Tal era, entretanto, a entrada em que se insistia desde Descartes, sendo que ainda Fichte abria sua Doutrina da Ciência convidando o leitor a um exercício de introspecção, uma série de meditações lógicas pelas quais qualquer ser racional descobriria em seu interior a verdade

${ }^{122}$ Id., Fenomenologia do Espírito, VI, B, 1-a -“A cultura e o seu reino da efetividade”, p. 341 (366). 
cabal do princípio supremo. Segundo Hegel, "uma assim chamada proposição fundamental (ou princípio) da filosofia, se é verdadeira, já por isso também é falsa, enquanto é somente proposição fundamental ou princípio. Por isso é fácil refutá-la. A refutação consiste em indicar-lhe a falha. Mas é falha por ser universal apenas, ou princípio; por ser o começo."123 Em Kant, esse apelo inicial à obviedade da certeza de si se dilui em uma ampla fé na clarividência da crítica da razão - e o adendo que punha em dúvida a verdade do princípio supremo promove antes um mero ajuste de execução, mantida a proposta de uma vasta analítica preliminar, que a certa altura se arroga a consciência crítica de que o eu puro não corresponde ao eu empírico apenas para continuar a aceitar o princípio supremo “problematicamente". Hegel, por sua vez, embarga a própria serventia de princípios de fundamentação. Assim ele abandona completamente a estratégia de submeter as categorias do pensamento a um exame prévio: é no furor da experiência que a fenomenologia as examinará.

\section{CAPÍTULO III \\ Literatura e experiência da consciência}

A constatação de que mesmo o fundamento da consciência precisa ser buscado na experiência é a centelha que ateia fogo ao rastilho fenomenológico. "Com efeito, a consciência, por um lado, é consciência do objeto; por outro lado, consciência de si mesma: é consciência do que é verdadeiro para ela, e consciência de seu saber da verdade. Enquanto ambos são para a consciência, ela mesma é sua comparação: é para ela mesma que seu saber do objeto corresponde ou não a esse objeto." ${ }^{124}$ Uma vez que o saber de si é um saber do objeto para a consciência; que, portanto, o objeto da consciência-de-si é simultaneamente a verdade da certeza e a certeza da verdade, ou, noutras palavras, uma vez que a verdade do objeto é também objeto da consciência, então a diferença entre a verdade do objeto e a certeza da consciência não é nem a diferença da certeza do objeto em relação a um eu idêntico e nem a diferença da verdade da consciência em relação a uma coisa-emsi. A comparação entre uma e outra não envolve nenhum pressuposto que não se expõe para

\footnotetext{
${ }^{123}$ Id., Fenomenologia do Espírito, Prefácio, p. 38 (27).

${ }^{124}$ Id., Fenomenologia do Espírito, Introdução, p. 79 (77-78).
} 
a consciência sob a forma determinada de um conteúdo determinado. Daí por que uma investigação preliminar sobre as condições de possibilidade da experiência só poderia mesmo levar a incógnitas: porque antes da experiência a consciência ainda não recebeu nem conteúdo e nem forma. E por isso Hegel não se dará ao despautério de examinar misteriosas tábuas de categorias sob o candeeiro bruxuleante da razão pura. Em vez de nos fazer perguntar por axiomas racionais, princípios apodícticos, pressupostos de validade, representações espontâneas, leis eternas e verdades cristalinas - em vez de procurar uma certeza inabalável a que possamos nos apegar com segurança, para só depois conhecer ou agir - Hegel defende, do contrário, que permaneçamos no campo de confronto entre a certeza e a verdade, onde estamos desde sempre, apesar das tentativas de fuga.

Do ponto de vista do kantismo, o fenômeno ou deixa escapar a coisa-em-si ou decompõe a essência absoluta, de modo que falar em manifestação para a consciência da verdade do objeto seria uma atribuição ilícita de conteúdo supostamente verdadeiro ao irrepresentável. Porém, segundo Hegel, ao reconstituir a experiência da consciência, rastreando seu percurso fenomenológico, o filósofo não supõe nenhum conhecimento prévio da verdade, porque a verdade que se manifesta para a consciência não precede a manifestação. O que se passa na experiência da consciência não é a ordenação de um objeto determinado para um sujeito absoluto, mas a elaboração de um conceito absoluto para um sujeito determinado.

Esse modo de encarar a comparação entre certeza e verdade deve animar os esforços de quem se dispõe a seguir pelo caminho da ciência em companhia do filósofo. E o convite não deixa de advertir contra o terreno acidentado. A manifestação gradual da verdade para a consciência, na experiência, compreende uma sucessão de choques contra a efetividade, nos quais a consciência, ao tentar realizar seu conceito, primeiro percebe e depois reconhece que sua certeza era verdadeira apenas para ela. A continuidade da experiência requer uma constante reformulação do conceito, ao longo e ao cabo da qual o verdadeiro se produz.

Na Fenomenologia do Espírito, a experiência da consciência é protagonizada por uma série de figuras [Gestalten]. O emprego de uma designação genérica para aludir ao sujeito da experiência, longe de caracterizar deficiência de apreensão de situações reais, ou subsunção dos agentes particulares a entidades ideais, está plenamente justificado, do 
contrário, ao menos para o próprio Hegel, pelo compromisso de não fazer uso arbitrário de verdades que ainda não se explicitaram, na medida em que a determinação de um sujeito concreto é meta bastante avançada do percurso fenomenológico, e não poderia ser imposta de início, a não ser como dogma metafísico ou profissão de fé - cogito ergo sum. Se a névoa de indeterminação que envolve o sujeito não pode ser abolida por um decreto inaugural, ninguém conseguirá dissipá-la sem respirar pelo caminho um ar enevoado.

Podemos nos reportar de diversas maneiras à oposição basilar de que parte a Fenomenologia do Espírito: é a oposição entre o sujeito e o objeto, o eu e o mundo, ou, em termos rigorosamente hegelianos, entre o "visar" [das Meinen] e o "isto" [das Dieses]. Uma vez que Hegel recusa qualquer conhecimento que não tenha sido adquirido por meio da experiência, esse modo peculiar de se referir a si e ao ser indica que a experiência da figura em questão se limita a ter apenas perpetrado a mera distinção entre um interior e um exterior, aos quais ela visa no maior grau de abstração possível. Hegel denomina certeza sensível à figura que opõe o "isto" ao "visar". Toda experiência da consciência se dá por sobre esta distinção elementar que a certeza sensível perpetrou. Quando o "isto" se torna outro, a certeza sensível percebe que o seu objeto de experiência não se deixa apreender pelo conceito de que ela dispõe. Até porque ela não dispunha nem sequer do conceito de objeto: o seu objeto era para ela apenas um “isto". E assim começa a longa experiência da consciência, que a fenomenologia se propõe a estudar. Conforme o saber de si da consciência se amplia, tanto mais ela própria amplia o seu campo de experiência, e a fenomenologia opera uma reordenação teorética em que o desenvolvimento da individualidade deixa de ser explicado apenas no âmbito das intuições epistemológicas e passa, por necessidade, a um terreno cada vez mais permeado por determinações históricas. No decorrer da jornada, cada rompimento da identidade entre a certeza e a verdade proporciona à consciência ocasião de assimilar novo saber a ser utilizado para fundamentar a próxima conduta que lhe parecer necessário adotar perante outras contingências da efetividade. Neste sentido, a Fenomenologia do Espírito é desde o início uma crítica incessante de todos os princípios de fundamentação já experimentados.

A origem da certeza sensível, a forma mais baixa de consciência, é explicada por Hegel em sua Antropologia, um tópico da Filosofia do Espírito na Enciclopédia das Ciências Filosóficas. No contexto da Fenomenologia, importa notar que o restabelecimento 
da identidade rompida pela certeza sensível se torna a meta de ação que cada uma das demais figuras recupera da anterior. A última figura, o saber absoluto, conseguirá finalmente efetivar a identidade a que a certeza sensível apenas visava. Mas isso não significa que a subjetividade científica conhecerá o ser determinado em máxima extensão e exata profundidade. Do contrário, o saber absoluto só poderá se realizar como negação definitiva dessa identidade visada, desfazendo a ilusão de se querer eliminar ou de se ter eliminado a oposição entre certeza e verdade, mas também ultrapassando o estágio de consciência particular. Em relação à objetividade do conhecimento, o saber absoluto substitui o problema de averiguar validade ou exatidão da transposição da realidade para a razão pelo problema de conceber a história dos momentos de adequação entre razão e realidade segundo uma oposição em si mesma necessária e determinante de ambas no processo. $\mathrm{O}$ critério de verdade não pode ser a correspondência entre a essência e o objeto da representação, mas a própria conexão entre objeto e representação deve ser considerada verdadeira enquanto necessária para um determinado momento da história da essência. A ciência precisa incluir o estudo de objetos espaciais na compreensão de processos temporais que envolvem a formação da própria subjetividade cognoscitiva.

Mas aqui não nos aprofundaremos na exegese da primeira e nem da última das figuras fenomenológicas. Evocamo-las tão-somente para orientar o encadeamento da série. Importa reter que a experiência produz, para a consciência, uma diferença entre o seu saber da essência e a essência: essa diferença é justamente a essência que aparece para a consciência como um novo objeto de saber, e assim sucessivamente.

Até agora, demoramo-nos em produzir a inteligibilidade desta densa obra de Hegel. Primeiro distinguimos o modo de operação do conceito por meio da negação determinada. Depois identificamos a individualidade como categoria central dessa operação na fenomenologia. Em seguida, com base nessa peculiaridade, situamos Hegel na problemática da filosofia moderna, sobretudo perante Descartes, Kant e Fichte. Esperamos ter conseguido mostrar que a reflexão sobre a experiência da consciência é o caminho empregado pela Fenomenologia do Espírito para refutar o conceito transcendental de sujeito e instaurar o pensamento conceitual - o que significa, para Hegel, a superação do conhecimento fenomênico, isto é, do pensar limitado à apercepção da consciência na experiência. 
Daqui em diante, prosseguiremos para o exame das figuras em que a consciência se percebe como indivíduo - o que vem a ocorrer a certa altura da Fenomenologia do Espírito, mais precisamente no segundo capítulo da Seção Razão, denominado "A efetivação da consciência-de-si racional através de si mesma". A exegese desse capítulo constitui, pois, a próxima tarefa do presente estudo. Neste trecho do percurso fenomenológico, Hegel expõe a formação da individualidade a partir do momento em que a consciência, após ter feito do mundo todo um objeto para si, pela primeira vez se determina a atuar segundo a certeza de ser universal.

Os temas que surgem em tela são a perda dessa certeza para os duros golpes do destino, a mudança de perspectiva em relação a si, a prostração causada pelo sentimento de fracasso, a necessidade de retificar enganos, de renovar esperanças, e de salvar a compreensão racional da realidade hostil que nega nossas representações. Hegel apresenta a efetivação da consciência-de-si racional no decorrer de uma tríade de figuras, tecendo considerações apoiadas em referências literárias que permeiam e articulam o texto de maneira mais ou menos direta, ora evidentes, ora nem tanto; ora por citações, ora por alusões. Nosso trabalho exegético, desta feita, inclui a necessidade de comentar as referências literárias do texto hegeliano, na medida em que este o solicita, reconstituindo a imbricação entre a experiência individual narrada pela literatura e o seu sentido fenomenológico.

O recurso de Hegel à literatura sugere que, neste período da história do espírito, a ascensão do indivíduo ativo coincide com a representação literária da efetivação singular enquanto drama universal. A literatura, por conseguinte, assume o papel de registro consciente da experiência humana, ou, inversamente, a experiência humana adquire consciência de si sob a forma de representação literária. De fato, pressentimos a marca de certa tragicidade no percurso fenomenológico desde que Hegel o caracteriza como uma sequiência de rupturas práticas com expectativas teóricas: "a consciência natural vai mostrar-se como sendo apenas conceito do saber, ou saber não real. Mas enquanto se toma imediatamente por saber real, esse caminho tem, para ela, significação negativa: o que é a realização do conceito vale para ela antes como perda de si mesma, já que nesse caminho perde sua verdade." 125 A consciência sofrerá sucessivas derrotas enquanto não compreender

${ }^{125}$ HEGEL, G. W., Fenomenologia do Espírito, Introdução, p. 74 (72). 
que a verdade de sua certeza sempre extrapola a apercepção do objeto momentâneo. "Por isso esse caminho pode ser considerado o caminho da dúvida [Zweifel] ou, com mais propriedade, caminho do desespero [Verzweiflung]; pois nele não ocorre o que se costuma entender por dúvida: um vacilar nesta ou naquela pretensa verdade, seguindo de um conveniente desvanecer-de-novo da dúvida e um regresso àquela verdade, de forma que, no fim, a Coisa seja tomada como era antes. Do contrário, ele é a penetração [Einsicht] na inverdade do saber fenomenal; para esse saber, o que há de mais real é antes somente o conceito irrealizado." ${ }^{26}$ Trata-se de uma luta incessante da consciência contra a precariedade do saber.

A primeira das três figuras literárias da individualidade está arrolada sob o título de "O prazer e a necessidade": Hegel aponta no Fausto ${ }^{127}$ de Goethe o surgimento de um projeto de autonomia individual que rompe com o padrão de racionalidade meramente contemplativa. Na segunda figura, intitulada "A lei do coração e o delírio da presunção", a individualidade enfrenta o desafio de conciliar esse projeto de autonomia com a ordem estabelecida no reino da efetividade - conflito que remete, como veremos, à experiência de Karl von Moor, protagonista da peça teatral "Os Bandoleiros", de Friedrich Schiller. A terceira figura, por fim, chama-se "A virtude e o curso-do-mundo", e retrata a autoefetivação da individualidade no contexto de um estado de coisas que lhe recusa o direito a aspirações sublimes. Desta vez, o inconfundível cavaleiro de Cervantes é quem deixa o rastro de suas andanças pelos meandros da dialética hegeliana.

Admitimos, com Hypollite, que compreender a aparição de vultos literários neste trecho do itinerário fenomenológico "é bastante difícil, não porque a passagem dialética de uma forma a outra seja inconcebível, mas porque a sucessão das figuras concretas tomadas de empréstimo à época - Fausto, Moor, Dom Quixote - parece bastante estranha como sucessão." ${ }^{128}$ A tarefa a que nos propomos consiste justamente em vencer essa dificuldade e essa estranheza, elucidando a relação entre a formação da individualidade na Fenomenologia do Espírito e as célebres personagens de Goethe, Schiller e Cervantes.

\footnotetext{
${ }^{126}$ Ibid., p. 74 (72).

${ }^{127}$ Em 1807 Hegel poderia ter conhecido apenas as principais cenas que viriam a compor a Primeira Parte da tragédia na obra completa. Goethe continuou a escrever a saga do Fausto por cerca de mais quatro décadas, até completá-la pouco antes de morrer, em 1832.

${ }^{128}$ HYPPOLITE, Jean. Gênese e Estrutura da Fenomenologia do Espírito de Hegel, p. 292.
} 


\section{PARTE: OBSERVAÇÃo FENOMENOLÓGICA DA INDIVIDUALIDADE}




\title{
CAPÍTULO I \\ Crítica da representação dualista do homem
}

$\mathrm{Na}$ primeira parte do presente estudo, vimos por que Hegel sustenta que a fundamentação metafísica do conhecimento seja substituída pela fenomenologia, "a tarefa de conduzir o indivíduo de seu estado inculto até o saber". ${ }^{129}$ As grandes figuras que pretendiam averiguar as condições de possibilidade da experiência terminavam embaraçadas em um conceito transcendental que fracassa em enunciar a realidade objetiva envolvida na determinação do sujeito.

Nesta seção veremos como a fenomenologia vem a encontrar, na reconstrução da experiência da consciência, a categoria que permitiria dispensar de fundamento transcendental um sistema de pensamento. Na seguinte passagem da Estética, em vista da influência que Fichte acabaria por exercer sobre a escola romântica, Hegel reafirma essa guinada da crítica ao Eu abstrato em direção a uma reflexão sobre a individualidade:

\begin{abstract}
Fichte estabelece o $\mathrm{Eu}$ e, na verdade, o Eu total e constantemente abstrato e formal, como princípio absoluto de todo saber, de toda razão e conhecimento. Em segundo lugar, esse Eu é por causa disso em si mesmo completamente simples; por um lado, nele são negados toda particularidade, determinação e conteúdo - pois todas as coisas sucumbem nesta liberdade e unidade abstrata -; por outro lado, todo conteúdo que deve valer para o Eu somente é estabelecido e reconhecido pelo Eu. O que é, somente é através de mim, e o que é através de mim posso do mesmo modo aniquilar novamente. Se, porém, ficamos presos a estas formas totalmente vazias que têm sua origem no caráter absoluto do Eu abstrato, nada é considerado em si e para si e em si dotado de valor, mas somente enquanto produzido pela subjetividade do Eu. E então o Eu também pode permanecer senhor e mestre de tudo o que existe e nada haverá em nenhuma esfera da eticidade, do direito, do humano e do divino, do profano e do sagrado que não necessite ser primeiramente estabelecido pelo Eu e que, por isso, também não possa igualmente ser destruído pelo Eu. Por causa disso, tudo o que é em-si-e-para-si é apenas uma aparência e não é verdadeiro e efetivo devido a si mesmo e por meio de si mesmo, mas um mero aparecer por meio do Eu que, com violência e arbitrariedade, dispõe livremente de tudo o que é em-si-e-para-si. Atribuir valor a algo ou superá-lo depende totalmente do bel-prazer do Eu que, enquanto Eu, já é absoluto em si mesmo. Em terceiro lugar, este Eu é indivíduo vivo, atuante, e sua vida consiste em fazer sua individualidade para si e para os outros, em se manifestar e se tornar fenômeno [sich zu äußern und zur Erscheinung zu bringen]. Pois cada homem, na medida em que vive, busca se realizar e se realiza. ${ }^{130}$
\end{abstract}

O excerto acima deixa clara a impropriedade de se imputar a Hegel certo comprometimento em justificar uma tirania sistemática do sujeito sobre o objeto, do Eu sobre o Outro, ou da razão sobre a vida. E ainda sugere que, na seara das idéias, a tirania medra mais perto da diluição da realidade na subjetividade do que da perseverança em ater

\footnotetext{
${ }^{129}$ HEGEL, G. W., Fenomenologia do Espírito, Prefácio, p. 41 (31).

${ }^{130}$ Id., Cursos de Estética, Introdução, p. 81-82. Tradução de Marco Aurélio Werle, grifo meu.
} 
a consciência àquilo que é "verdadeiro e efetivo devido a si mesmo e por meio de si mesmo".

A reflexão hegeliana sobre a individualidade visa a superar o dualismo entre corpo e alma que prevalecia na filosofia pelo menos desde que Descartes preceituara ser a alma "uma substância inteiramente distinta do corpo."131 Vimos como Kant e Fichte permaneceram presos a essa rígida estratificação. Mas nenhum passo adiante se teria dado caso a assertiva hegeliana de que a verdade do Eu reside no "indivíduo vivo e atuante" evocasse uma reconciliação teórica do dualismo na figura de um corpo animado ou de uma alma encarnada. A mediação que Hegel assinala dar-se no indivíduo reporta, do contrário, à reconciliação prática entre particular e universal que ocorre porque "mediante o Si enquanto alma a substância é plasmada em seus momentos". ${ }^{132}$ Em vez de deduzir o campo de experiência do indivíduo de um fundamento transcendental, Hegel se propõe a explicitar como o indivíduo mesmo plasma a substância universal que lhe serve de fundamento.

Tomando-se o indivíduo por objeto, seja como for, nem a representação de uma alma encerrada no corpo e nem a de um corpo dotado de alma exprimem o próprio indivíduo como sujeito universal. A origem de sua alma permanece incógnita, e ao dualismo resta explicar a alma como predicado de um sujeito estranho. Mas o dualismo já está suplantado na unidade que a consciência precisa estabelecer com a efetividade para entrar em ação. "Essa unidade negativa do pensar é para si mesma, ou melhor, é o ser-parasi-mesmo, o princípio da individualidade; e é, em sua realidade, consciência operante". ${ }^{133}$ Eis que se manifesta a necessidade de considerar a atividade da alma, o seu confronto com o múltiplo, de modo mais abrangente do que a mera apercepção cognoscitiva. Para Kant, a alma era apenas um "objeto do sentido interno", ${ }^{134}$ e sua única atividade era conhecer. A estratégia hegeliana amplia enormemente o campo de observação dos fenômenos de exteriorização da subjetividade.

A filosofia moderna, até então, consagrara seus maiores esforços à investigação do funcionamento da consciência, das leis racionais do entendimento, da estrutura interna do

\footnotetext{
${ }^{131}$ DESCARTES, René., Princípios da Filosofia, $\$ 8$.

${ }^{132}$ HEGEL, G. W. Fenomenologia do Espírito, VI, B, 1-a -“A cultura e o seu reino da efetividade”, p. 341 (366).

${ }^{133}$ Id., Fenomenologia do Espírito, V , A, b - "Observação da consciência-de-si em sua pureza e em referência à efetividade exterior: leis lógicas e leis psicológicas”, p. 218 (228-229).

${ }^{134}$ KANT, I., Crítica da Razão Pura, Capítulo Primeiro do Livro Segundo da Dialética Transcendental, p. 261.
} 
Eu. A fenomenologia constata que por sobre essas bases não se consegue explicar satisfatoriamente o homem: "pois cada homem, na medida em que vive, busca se realizar e se realiza." Se a atividade vital dos indivíduos consiste em implementar a consciência no ser, então a ciência precisa se abrir aos processos pelos quais a potência subjetiva se transfunde para a objetividade.

\section{CAPÍTULO II \\ Da noite da possibilidade ao dia da presença}

A crise da fundamentação metafísica do conhecimento se patenteia quando a ciência moderna elege o homem para objeto de estudo. Na terceira seção da Fenomenologia do Espírito, Hegel enceta polêmica contra três ramos do conhecimento dedicados à investigação da individualidade: a Psicologia, a Frenologia e a Fisiognomonia. Levantemos alguns elementos notáveis dessa reflexão.

a) Psicologia

Pertence a Christian Wolff (1679-1754) a decantada divisão da Psicologia em Psicologia Empírica e Psicologia Racional, esta dedicada a indagações metafísicas sobre a origem da alma, e aquela ao estudo da subjetividade enquanto fenômeno da experiência humana. Na crítica do paralogismo, Kant reafirma essa divisão ao destituir a Psicologia Racional de objeto real. Parece, pois, que restaria ao outro ramo a possibilidade de angariar algum conhecimento do Eu. Dentre os estudos de Psicologia Empírica se destaca o famoso tratado de Descartes acerca Das Paixões da Alma, no qual são descritos, com profusão de detalhes, os variegados estados de ânimo e as influências recíprocas entre corpo e mente.

Hegel considera que, ao adotar o procedimento de observação da individualidade, a Psicologia empreende uma primeira tentativa de condicionar as formas da consciência à experiência. O método empírico desloca o foco da disciplina, do exame das faculdades de um sujeito amorfo para a apreensão dos predicados da consciência finita. Deixando de lado o problema do dualismo, a Psicologia chega a reconhecer no indivíduo a unidade da consciência com o seu contrário. 
A psicologia observadora enuncia, primeiro, suas percepções dos modos universais que se lhe apresentam na consciência ativa; encontra numerosas faculdades, inclinações e paixões. Ora, na enumeração de tal coleção não se deixa reprimir a lembrança da unidade da consciência de si; por isso a psicologia deve, ao menos, chegar até o ponto de maravilhar-se de que possam estar juntas no espírito, como num saco, tantas coisas tão contingentes e heterogêneas, especialmente porque não se mostram como coisas mortas, mas como movimentos irriquietos. Na enumeração dessas diversas faculdades, a observação está no lado universal: a unidade dessas múltiplas capacidades é o lado oposto a essa universalidade: a individualidade efetiva. ${ }^{135}$

Mas Hegel também adverte que a Psicologia não pode se desembaraçar da metafísica simplesmente delegando a investigação das condições de existência da alma a uma especialidade teórica que se reduziu ao diletantismo, paralisada pela incognoscibilidade da essência absoluta. Ele nos mostra como a insolvência teórica se faz sentir na ciência aplicada, na medida em que mesmo o estudo descritivo do eu fenomênico continua minado pelo conceito transcendental de sujeito. A persistência da unidade sintética originária como princípio operador do entendimento relega a observação psicológica àquele "procedimento raciocinante" 136 de atribuir inúmeros predicados ao sujeito sem jamais formular o conceito que lhe determine a essência, e que leva, no caso, a um catálogo de sedes anatômicas das múltiplas disposições anímicas.

A Psicologia só reconhece a unidade entre corpo e alma como um objeto empírico sob a mira da razão; isto é, ela representa a individualidade separada de "sua natureza inorgânica universal, ou seja, as circunstâncias, situações, hábitos, costumes, religião etc. que são 'achados' e em função dos quais a individualidade determinada tem de ser concebida". ${ }^{137}$ Se não se leva em conta a influência dessas circunstâncias determinadas sobre a individualidade, aniquilando-se a universalidade na figura abstrata do Eu, então as disposições anímicas parecem ser apenas predicados intrínsecos que não têm nenhuma razão precisa para se manifestarem de certo modo na vida sensível, e "a necessidade psicológica se torna uma palavra tão vazia que se dá a possibilidade absoluta de que o indivíduo que teria tido aquela influência pudesse também não ter tido."138 O universal não pode ser um elemento indiferente; há de se considerar o papel do mundo na conformação

\footnotetext{
${ }^{135}$ HEGEL, G.W., Fenomenologia do Espírito, V, A, b - “Observação da consciência-de-si em sua pureza e em referência à efetividade exterior: leis lógicas e leis psicológicas,” p. 219 (230).

${ }^{136}$ Id., Fenomenologia do Espírito, Prefácio, p. 62 (56).

${ }^{137}$ Id., Fenomenologia do Espírito, V, A, b - "Observação da consciência-de-si em sua pureza e em referência à efetividade exterior: leis lógicas e leis psicológicas,” p. 220 (231).

${ }^{138}$ Ibid., p. 221 (232).
} 
da alma. Assim, a principal objeção de Hegel à Psicologia recai sobre a pretensão de deduzir o caráter do indivíduo de uma análise da interioridade.

\begin{abstract}
Tem menos interesse do que descrever as espécies de insetos, musgos etc., isso de apreender as diferenças efetivas, de modo a descrever um homem como tendo mais inclinação a isso, e outro, mais inclinação àquilo; que fulano tem mais inteligência que sicrano. De fato, espécies vegetais e animais dão à observação o direito de tomá-las assim, de modo singular e carente-de-conceito, pois pertencem essencialmente ao elemento da singularização contingente. Ao contrário, tomar a individualidade consciente de uma maneira carente-de-espírito, como fenômeno singular essente, tem a contradizê-lo o fato de que sua essência é o universal do espírito. ${ }^{139}$
\end{abstract}

Na polêmica contra a Psicologia, ainda, ao discutir sobre como a universalidade do espírito deveria ser conceitualmente incorporada à determinação da individualidade, Hegel parece defender-se de vindouros detratores, com a advertência de que representar o indivíduo como particularização de um estado do mundo, em contrapartida, também não resolve o problema. "Circunstâncias, situações, costumes etc., que uma vez são indicados como dados, e outra vez são indicados nesta individualidade determinada, somente exprimem a essência indeterminada da individualidade - da qual não se trata aqui." ${ }^{\text {"140 }}$ De fato, não há grande diferença entre explicar o indivíduo como manifestação de predicados intrínsecos ou como confirmação de predicados extrínsecos, pois, no segundo caso, o pensamento ainda opera segundo a mesma dicotomia. Hegel não aceita conceber a individualidade como fruto da configuração do mundo; isto é, ele também não aceita, em remedeio ao subjetivismo psicológico, que o caráter do indivíduo seja deduzido de uma análise do estado de coisas ou identificado a características gerais da época. "Fosse o exterior constituído, em si e para si, tal como se manifesta na individualidade, essa seria bem compreensível a partir dele. Teríamos então uma dupla galeria de quadros, em que uma seria reflexo da outra; uma, a galeria da determinidade completa e da delimitação das circunstâncias exteriores; outra, a mesma galeria, mas traduzida nessa modalidade segundo a qual as circunstâncias estão dentro da essência consciente." ${ }^{\text {"141 }} \mathrm{O}$ caráter seria decidido por uma conjunção de fatores objetivos, de modo que cada momento do desenvolvimento da individualidade corresponderia a um arranjo estabelecido no plano das constelações, das instituições, da religião, da arte, da ciência, da história, enfim - da substância universal.

\footnotetext{
${ }^{139}$ Ibid., p. 221 (232).

${ }^{140}$ Ibid., p. 220 (231).

${ }^{141}$ Ibid., p. 221 (232).
} 
Todavia, segundo Hegel, não é esse o caso. O indivíduo não está para o mundo como uma árvore para a paisagem; ele não está para o espírito da época como que amarrado perante um espelho. E por que não?

Eis o argumento fundamental: nada vem a ser para a individualidade senão por meio dela mesma. "Essa individualidade consiste justamente nisto: em ser o universal e portanto em confluir de uma maneira tranqüila imediata com esse universal que está presente como costumes, hábitos etc.; e, ao mesmo tempo, em comportar-se como oposta a eles, e portanto em subvertê-los; como também comportar-se, em sua singularidade, com total indiferença a seu respeito, não os deixando agir sobre ela, nem sendo ativa contra eles." ${ }^{\text {"142 }} \mathrm{Em}$ suma, a concordância originária entre singular e universal pode ser negada em ato. O ser singular é sempre universal em si, mas para si ele pode ser apenas singular, e neste caso será a negação o determinante da universalidade que o ser singular se dá. Assim, do fato de o indivíduo pertencer à substância não se segue que sua conduta esteja predeterminada unilateralmente. Em primeiro lugar, porque as circunstâncias exteriores só ganham influência sobre o indivíduo conforme o modo determinado como ele próprio responde a elas. Em segundo, porque sua resposta admite ao menos duas possibilidades: ou aceitar ou recusar, em diversos graus e de várias maneiras, as influências que recebe do mundo. "Só da própria individualidade depende, pois, o que deve ter influência sobre ela, e qual influência isso deva ter - o que vem a dar exatamente no mesmo. Portanto, dizer que tal individualidade, mediante essa influência, se tornou esta individualidade determinada não significa outra coisa senão que ela já era isso antes." ${ }^{143}$ Engana-se quem considera o indivíduo uma repercussão do estado do mundo sob alegação de que é de sua essência ser universal. Que a individualidade necessariamente dê vazão ao fluxo do espírito ainda não revela nada de determinado sobre ela. E esta inflexão mobiliza muito mais do que a ênfase na margem de liberdade individual envolvida na definição do destino. Simultaneamente, para Hegel, trata-se de introduzir o negativo no conceito de manifestação fenomênica. $O$ fenômeno não deve ser concebido como repetição desvelada de um mesmo conteúdo originário. Mais do que resguardar a oposição ao universal como possibilidade formal de conduta, Hegel está a defender que a manifestação pela negação constitui a verdadeira via

\footnotetext{
${ }^{142}$ Ibid., p. 220 (231).

${ }^{143}$ Ibid., p. 220 (231).
} 
de determinação da essência da individualidade. (Lembremo-nos de Fichte, para quem a negação do eu puro pelo eu empírico era tão-somente uma perda de si que nada afirmava além de uma dívida impagável da existência para com a essência.) A peculiaridade do indivíduo decorre dos atos com que ele se diferencia, e não dos atributos que o igualam ao todo. Não há que se falar em determinação enquanto o indivíduo apenas espelha as influências a que se submete. Dizer que "o indivíduo não seria o que é se essas circunstâncias, maneiras de pensar, costumes, estado-do-mundo em geral não tivessem sido" ${ }^{144}$ é apenas uma obviedade, válida para todos os casos ocorridos sob as mesmas condições. A determinação da verdadeira essência universal do indivíduo consiste não em evidenciar a universalidade do ser singular, mas em distinguir a singularidade do ser universal.

Tranquillo quilibet gubernator est. ${ }^{*}$ Se o indivíduo apenas confluísse com o leito da vida, sem nenhuma revolta - se ele jamais se chocasse contra imposições superiores, se jamais divergisse dos preceitos vigentes, se jamais ofendesse esperanças alheias - então mesmo assim essa aparente passividade perante o estado do mundo ainda seria, na verdade, ativa: pois neste caso ele próprio "teria feito entrar em si o mundo tal como é, comportando-se a seu respeito como consciência formal." ${ }^{\text {"45 }}$ Mas a dinâmica da experiência individual não se resume a singrar serenamente a substância universal, como um timoneiro qualquer. A influência da efetividade sobre o indivíduo também "recebe, através desse indivíduo, o sentido inteiramente oposto: o indivíduo ou deixa correr imperturbado o fluxo da efetividade que o influencia, ou então o interrompe e o inverte."146 E o conceito de individualidade não deveria ignorar sobretudo a segunda alternativa, porque só pela conduta negativa a identidade imediata da essência se quebra e a consciência formal vem a adquirir conteúdo próprio - a singularidade surge. Assim, o modo necessário de manifestação da efetividade na singularidade não está determinado em potência. Tomar o espírito por senhor absoluto do destino leva à mera representação de uma existência formal, como se o mundo transferisse para a individualidade o caráter que ele engendrou primeiro. "Como, pois, a efetividade é susceptível de uma dupla significação em virtude

\footnotetext{
${ }^{144}$ Ibid., p. 220 (231).

${ }^{145}$ Ibid., p. 220 (231).

${ }^{146}$ Ibid., p. 220 (231).

* Na calmaria, qualquer um é timoneiro. - Sêneca, Epistulae Morales 85.34
} 
dessa liberdade, então o mundo do indivíduo tem de ser concebido a partir do indivíduo mesmo." 147

\section{ß) Frenologia e Fisiognomonia}

Se a Psicologia se consagra à análise da alma, a Frenologia e a Fisiognomonia, por sua vez, procedem à observação do objeto oposto, tentando descobrir o caráter do homem pela investigação de traços corporais: feições e proporções de um indivíduo dariam a conhecer sua exata propensão para determinada conduta. A veemência com que Hegel repudia esses estudos salta aos olhos do leitor versado na habitual sobriedade estilística do filósofo. Pois se, por um lado, a Psicologia falha em determinar a influência da objetividade, nenhum ganho de objetividade se obtém, por outro, com a associação do caráter a predicados objetivos. A Frenologia e a Fisiognomonia pretendem corrigir o subjetivismo da Psicologia com a hipótese de que as disposições anímicas provenham de respectivos lineamentos físicos. Mas supor que a essência espiritual do indivíduo possa ser identificada pela figura do corpo é um erro ainda maior, porque cassa a autonomia moral do homem na própria singularidade.

Socorramo-nos de Ronaldo Mourão para enriquecer a exposição deste tema. $\mathrm{O}$ erudito astrônomo situa a Frenologia e a Fisiognomonia na história da ciência, em avaliação bastante convergente com a precursora crítica hegeliana:

A frenologia (do grego: phrén, mente; e logos, estudo) é a teoria do neurologista alemão Franz Joseph Gall (1758-1828) relativa à localização das funções cerebrais, primeira das tentativas científicas de medir o formato do crânio e tentar estabelecer uma relação com o caráter e a personalidade do indivíduo. Além de ser considerado o fundador e pai da frenologia, Gall foi um dos primeiros a sugerir cientificamente o cérebro como sede de todas as atividades mentais. Em Paris, na obra Sur les fonctions du cerveau (1825), escreveu sobre "a anatomia e fisiologia do sistema nervoso em geral e do cérebro em particular, com as observações sobre a possibilidade de reconhecer várias disposições intelectuais e morais do homem e dos animais pela configuração de seu crânio.” Muito popular no século XIX, a frenologia está desacreditada e classificada como uma pseudo-ciência. No entanto, recebeu crédito como uma proto-ciência por ter contribuído para a ciência médica com as idéias de que o cérebro é o órgão da mente com áreas específicas relacionadas a determinadas funções. (...) (...) Enquanto o anatomista e fisiologista alemão Gall acreditava na frenologia, o teólogo, filósofo e poeta suíço Johann Kaspar Lavater (1741-1801) concebeu a fisiognomonia. (...) A fisiognomonia (do grego physis, natureza, e gnómon, que conhece) pretendia associar a aparência física - em especial o rosto humano - com um determinado comportamento e, embora atualmente não possua autoridade científica, sendo considerada uma pseudo-ciência, conheceu o seu esplendor no século XIX. A

\footnotetext{
${ }^{147}$ Ibid., p. 220 (231).
} 
fisiognomonia tem suas raízes num fato psicológico: temos uma tendência a atribuir, de modo irrefletido, uma personalidade, um caráter ou qualidades morais a um indivíduo a partir da observação de seu aspecto físico (pessoas gordas, redondas, por exemplo, evocam doçura moral etc.). A fisiognomonia tentou fundamentar-se cientificamente com base nessa observação e na experiência empírica de julgar as pessoas pela sua fisionomia, estabelecendo de início algumas regras e, a partir daí, tentando enunciar leis. Ao procurar objetivamente as causas de um fato (tentando constituir uma ciência) para não ficar limitada a um julgamento subjetivo (psicologia intuitiva), a fisiognomonia coordenou numerosas proposições de um ponto de vista pseudocientífico, o que impossibilitou a elaboração daquelas leis. A principal meta da fisiognomonia era, através das medidas de diferentes ângulos (por exemplo, a saliência do queixo), de formas (uma cabeça quadrada ou mais oval), das imperfeições etc., deduzir a personalidade de um indivíduo. As medidas permitiriam a matematização dos dados - o que, por sua vez, permitiria a pretensão de uma certa objetividade na nova "ciência". Mas essa teoria se baseava em critérios totalmente subjetivos; assim, por exemplo, um ângulo de mais de $45^{\circ}$ entre o eixo da mandíbula e o eixo do nariz - ou seja, uma relação quantitativa - determinaria um comportamento agressivo. Neste ponto mostrou seu interesse em constituir-se em ciência, segundo as normas adotadas no século XIX para definir uma disciplina como ciência: a partir da observação de um fato ou fenômeno que poderia ser matematizado e, em seguida, por indução de leis universais, procedendo de maneira análoga à astronomia, numa imitação grosseria para obter o sucesso de Isaac Newton. ${ }^{148}$

Vimos que a plataforma filosófica de Hegel acusa a mecânica clássica de inépcia para servir de modelo ao conhecimento científico. Eis agora o momento em que essa inépcia se manifesta com máxima severidade. A razão se propõe a conceber o homem, mas continua presa aos procedimentos de investigação da natureza. Segundo Théophile Thoré (1807-1869), autor de um dicionário de Frenologia e Fisiognomonia, as pesquisas empíricas da antropologia moderna acorriam à necessidade teórica de "absorver a dualidade na unidade."149 Para Hegel, entretanto, tudo o que elas conseguiram foi executar a pura negação da verdadeira síntese de extremos. Hegel mostra como as tentativas de superar o dualismo no interior da velha ciência resultam em empulhações grotescas.

A esta altura começamos a enxergar a porta de saída que abre para a posterior elaboração do conceito de indivíduo na "efetivação da consciência-de-si racional através de si mesma". ${ }^{150}$ Ao explicar por que a cognição do organismo humano não pode fornecer conhecimento do modo necessário de manifestação do caráter, Hegel paulatinamente apresenta elementos da filosofia da ação em cujo âmbito a individualidade deve ser compreendida. Assim, se a Frenologia e a Fisiognomonia acham que a figura de um homem já basta para "exprimir o que ele 'visa' por seus atos, ou o que se acredita ser ele capaz de

\footnotetext{
${ }^{148}$ MOURÃO, R., $O$ animal filosófico, p. 80-83.

${ }^{149}$ THORÉ, T., De la phrénologie dans ses rapport avec l'art apud MOURÃO, R., O animal filosófico, p. 82.

${ }^{150}$ HEGEL, G. F., Fenomenologia do Espírito, V, B - "A efetivação da consciência-de-si racional através de si mesma”, p. 249 (263).
} 
fazer", ${ }^{151}$ a filosofia deve, em contrapartida, "afirmar só o ato como o ser autêntico do homem; e não sua figura". ${ }^{152}$ Pois só o ato torna efetivamente perceptíveis os movimentos de alma que antes dele se escondiam dentro do corpo. Embora o ato, tal qual o corpo, ainda seja objeto de apercepção - e, portanto, algo cuja representação isolada não suporta integralmente a essência do caráter - ocorre que nele a essência interior se dá a conhecer justamente porque ela saiu da interioridade.

O ato é algo simplesmente determinado, um universal, algo a ser apreendido em sua abstração: é homicídio, furto ou benefício, ato heróico etc. Pode-se dizer do ato que ele é. (...) O ato é isto, e o homem individual é o que o ato é. Na simplicidade desse ser o homem é para os outros homens uma essência universal essente, e deixa de ser algo apenas 'visado'. ${ }^{153}$

Hegel segue o ensinamento aristotélico de que possuímos fins, mas só deliberamos sobre meios. A consecução do ato exige que a consciência se ajuste à efetividade, sem o que nenhuma intenção chega a ser implementada. Não é possível fazer o que não se quer fazer. $\mathrm{O}$ ato acontece quando a intenção teórica se encontra com o objeto da vontade prática. Por conseguinte, a redução da potência ao ato elimina a névoa de indeterminação que impedia a essência da individualidade de ser apreendida no interior da alma ou deduzida de características externas. É a consecução do ato que torna necessária a relação possível entre o interior e o exterior. A potência encerra possibilidades infinitas, mas o ato determina quais dessas possibilidades são realmente essenciais. A cada ato ocorre algo decisivo, pois

(...) o ato suprassume [hebt auf] a inexprimibilidade do 'visar', igualmente no que se refere à individualidade consciente-de-si, que no 'visar' é uma individualidade infinitamente determinada e determinável. No ato consumado, essa falsa infinitude é aniquilada. ${ }^{154}$

Disso decorrem amplas e profundas consequiências. $\mathrm{O}$ ato põe a intenção em prática, isto é, ele ultrapassa o momento de ação formal da consciência, e, portanto, jamais poderia ser o interior como interior na exterioridade. O indivíduo precisa suportar a negação da subjetividade se a quiser realmente implementar. E pode até mesmo acontecer que o ato consumado entre novamente em conflito com a intenção; que, após o ato, quando a

\footnotetext{
${ }^{151}$ Id., Fenomenologia do Espírito, V, A, c - "Observação da consciência-de-si com sua efetividade imediata: Fisiognomonia e Frenologia”, p. 231 (243).

${ }^{152}$ Ibid., p. 231 (243).

153 Ibid., p. 231 (243).

${ }^{154}$ Ibid., p. 231 (243).
} 
identidade entre meios e fins se desvanece, o indivíduo, confrontado com um mau resultado, venha a se recompor interiormente de modo a negar sua obra. "A obra é a realidade que a consciência se dá."155 Mas mesmo que o homem se recuse a reconhecer-se na própria obra, "é somente a obra que se deve considerar como sua efetividade verdadeira, ainda que o homem esteja iludido a seu respeito, e ao retornar a si mesmo de sua operação acredite que nesse interior ele é um outro do que [era] no ato." ${ }^{, 156}$ A oposição da consciência formal ao próprio conteúdo não rompe o vínculo determinante do sujeito com o objeto. É preciso aceitar a verdade que destrói uma certeza como a verdade própria dessa certeza. Aquilo que se exterioriza é a manifestação da integralidade da verdade.

A incipiente questão de saber em que exata medida um indivíduo deve responder por ato que desencadeie resultado inesperado engrossa o rol de preparativos fenomenológicos para a ulterior Filosofia do Direito: quando as conseqüências contrariam ou extrapolam a intenção, cabe a este perpetrar uma separação que não pertence à essência do ato, imputando ao indivíduo somente o resultado a que ele visava. Assim, sob certas condições, o indivíduo recebe o direito de se eximir da obra. O direito de restituir a perspectiva subjetiva contra a realidade opõe a responsabilidade moderna ao conceito de culpa do mundo antigo, no qual, a exemplo de Édipo, o indivíduo era culpado pelo ato independentemente de sua intenção.

Porém, no que diz respeito à determinação do caráter, não há que se levar em conta o peso morto da potência abstrata. Hegel considera impostura a insistência em viver sob a égide da falsa infinitude. A individualidade estará enganando a si mesma se teimar que a sua essência se perdeu no ato consumado. "A objetividade não altera o ato mesmo; somente mostra o que ele é, quer dizer, se é ou não é nada. " ${ }^{157}$ Em suma, não existe conteúdo que subsista à sua forma de manifestação. $\mathrm{O}$ exterior exprime a essência sem deixar qualquer resíduo de pureza, pois "o que constitui o caráter do ato é isto: ser ou um Ser efetivo que se conserva; ou apenas uma obra "visada', que some na sua nulidade." 158 A individualidade não tem nenhum fundamento para exigir o reconhecimento de intenções e capacidades não

\footnotetext{
${ }^{155}$ Id., Fenomenologia do Espírito, V, C, a - "O reino animal do espírito e a impostura - ou a Coisa mesma", p. $283(300)$.

${ }^{156}$ Id., Fenomenologia do Espírito, V, A, c - "Observação da consciência-de-si com sua efetividade imediata: Fisiognomonia e Frenologia”, p. 231 (243).

${ }^{157}$ Ibid., p. 231 (243).

${ }^{158}$ Ibid., p. 231 (243).
} 
realizadas. A explicitação da potência é condição necessária para o reconhecimento da interioridade.

y) Órgãos de manifestação e processo de exteriorização

O indivíduo começa a se exteriorizar pelos órgãos do corpo. "Só depois ele se exprimirá mais amplamente, saindo para o exterior em sua efetividade no mundo." ${ }^{159}$ Nos órgãos reside o agir do espírito. "A boca que fala, a mão que trabalha - e também as pernas, se quiserem - são órgãos que efetivam e implementam, que têm neles o agir como agir ou o interior como tal." 160 A presença do agir no órgão "constitui ao mesmo tempo uma exterioridade desse agir, e, sem dúvida, uma exterioridade diversa da que é o ato, já que essa nova exterioridade fica para o indivíduo e no indivíduo."161 O órgão reúne em si o interior e o exterior e "deve ser tomado como meio-termo dos dois"162 porque sua exterioridade ainda não ganhou independência. Já o ato, por sua vez, assinala ruptura entre a atividade dos órgãos e a obra consumada: "a exterioridade que o exterior ganha mediante os órgãos é o ato, como uma efetividade separada do indivíduo." ${ }^{163}$ Isso significa que a obra consumada passa a existir como objeto autônomo - como um ser-para-outro cuja essência é determinada pelo indivíduo, mas que se subtrai do ser-para-si dele.

Dentre todos os órgãos do corpo, a mão e a boca se destacam pela acuidade de intervenção, pois “o movimento que o indivíduo tem no fígado, no coração etc não pode ser considerado como movimento seu, de todo em si refletido (...)". ${ }^{164}$ Fígado e coração são órgãos que mal conseguem exteriorizar o espírito para além de si próprios e por meio de si próprios - eles se prestam mais à interiorização do que à exteriorização, mais ao sofrimento passivo do que à atitude resolutiva - este propaga os batimentos surdos do amor, aquele dissemina os humores turvos da cólera. Assim, no que diz respeito ao modo de implementar a consciência, de obter a realização de um fim, "o indivíduo terá sua

\footnotetext{
${ }^{159}$ Ibid., p. 227 (238).

${ }^{160}$ Ibid., p. 224 (235).

${ }^{161}$ Ibid., p. 226 (237).

${ }^{162}$ Ibid., p. 226 (237).

163 Ibid., p. 224 (235).

${ }^{164}$ Ibid., p. 233 (246).
} 
manifestação e exterioridade primeiro na boca, na mão, na voz, na escrita à mão". ${ }^{165}$ Sem descer a pormenores quanto aos demais órgãos, cumpre apenas indicar que neste capítulo, ainda a propósito da Frenologia, Hegel discorre amplamente sobre a relação do espírito com o sistema nervoso, afastando inclusive o equívoco de se identificar a consciência com o cérebro, e comenta, por fim, sobre o sentido humano da coincidência entre os aparelhos urinário e sexual, onde as funções mais baixas do indivíduo se unem às mais elevadas.

A mão e a boca, os órgãos do trabalho e da linguagem, são os meios de exteriorização que exprimem o conteúdo da interioridade com maior transparência. Porém, por mais hábeis que os meios sejam para configurar a obra, o indivíduo não pode evitar o momento em que ela finalmente escapa ao seu domínio. "Linguagem e trabalho são exteriorizações [Äusserungen] nas quais o indivíduo não se conserva nem possui mais em si mesmo; senão que nessas exteriorizações faz o interior sair totalmente de si, e o abandona a Outro."166 A identidade da obra consumada sofre determinações alheias. Eis aí a razão do desespero da consciência - o desespero de tomar a própria essência por objeto e já não reconhecê-la mais.

A experiência da consciência é uma concatenação de atos. Assim, a essência absoluta da individualidade se implementa ao longo de sucessivos confrontos da consciência com a objetividade. "Sobre o absoluto, deve-se dizer que é essencialmente um resultado; que só no fim é o que é na verdade." 167 O veredicto hegeliano de que o absoluto não se separa de sua atualização deve ser compreendido não no sentido de que o desenvolvimento se limita a corroborar um conteúdo dado em potência, mas no de que a potência mesma só adquire conteúdo por meio do processo de exteriorização. O resultado desse processo como um todo é a completa aniquilação da falsa infinitude para o pensamento. Mas para compreender que o ser-para-si da potência cria a essência e que o ser-para-si da essência exprime o inteiro teor da potência, a individualidade precisa fazer experiência de que tem sua verdade na exterioridade de si.

\footnotetext{
165 Ibid., p. 227 (238).

${ }^{166}$ Ibid., p. 224 (235).

${ }^{167}$ Id., Fenomenologia do Espírito, Prefácio, p. 36 (24).
} 


\section{CAPÍTULO III \\ A efetivação da consciência-de-si racional através de si mesma}

Vimos que as invectivas hegelianas contra a Psicologia, a Frenologia e a Fisiognomonia são abalizadas por um denominador comum: nos três casos, trata-se de expor a deficiência de representações que reduzem o indivíduo a objeto de apercepção. Vimos também que Hegel compreende a inópia intelectual dessas disciplinas como sintoma de esgotamento do padrão de racionalidade da filosofia da natureza.

\footnotetext{
Que espera ainda a cabeça que se crava

Só na matéria estéril, rasa e fria,

Wie nur dem Kopf nicht alle Hoffnung schwindet,

Que por tesouros com mão cobiçosa cava

E ao encontrar minhocas se extasia?

Der immerfort an schalem Zeuge klebt,

Mit gier' ger Hand nach Schätzen gräbt,

Und froh ist, wenn er Regenwürmer findet! ${ }^{168}$
}

Goethe registrou à sua maneira o momento desse esgotamento, em que a ciência relegara o sábio ao desalento de estudar uma infinidade invencível de objetos sem nunca penetrar no âmago do mundo. O critério kantiano de se condicionar o uso legítimo da razão a premissas empíricas consagrava como ciência uma espécie de materialismo epistemológico que se incumbia de ampliar o domínio extensivo do conhecimento. Expoente máximo dessa época foi o famoso naturalista Alexander von Humboldt (17691859), autor de vastos compêndios sobre física, química, geografia, geologia, mineralogia, cosmologia, anatomia, zoologia e botânica, disciplina onde logrou extraordinário prestígio por coletar, catalogar, ilustrar e descrever milhares de espécimes de plantas.

A restrição metodológica da ciência ao campo experimental, em nome de uma objetividade aparentemente alheia ao sujeito, produziu, à sombra de renomados doutores, gerações de epígonos tomados pela sensação de esmagamento perante a enormidade do todo. Muitos seguiram o rumo de esvaziar o saber absoluto pela abjuração filosófica da coisa-em-si - o que devolve a verdade da essência para o domínio inconcludente do diletantismo teórico e das crenças privadas. Mas a angústia de Fausto com a desespiritualização da ciência não se há de apaziguar pelo arejamento metafísico do conhecimento fenomênico. Ao menos do ponto de vista hegeliano, a sede de conhecimento

\footnotetext{
${ }^{168}$ GOETHE, J. W., Fausto, cena "Noite”, p. 81
} 
da essência absoluta não se confunde com aspiração à revelação de uma estrutura geral da realidade. Sendo o absoluto resultado de seu processo de exteriorização, determinar a procedência do fenômeno significa conceber a história da formação do próprio objeto enquanto sujeito, ao invés de desvendar mecanismos ocultos que o engendrariam como manifestação do cosmos. Noutras palavras, a ciência precisa dar conta de expor, para cada momento do desenvolvimento da essência, qual é a consciência de si que a consciência do objeto pressupõe. ${ }^{169}$

Assim começamos a perceber como a busca fenomenológica pela determinação da essência absoluta da individualidade se cruza com a literatura universal. Para além de afinidades temáticas com a filosofia, Hegel encontra na literatura uma forma de racionalidade que faz transição do padrão de cognição do ser em direção à primazia conceitual do devir.

A peculiaridade do registro literário está em representar a individualidade no decurso da ação. Essa fluidez pictórica é a grande vantagem da literatura sobre gêneros mais dependentes de meios materiais, como a pintura e a escultura, que precisam se ater a um único momento exclusivo ou a uma situação em si mesma estática. Na Estética, Hegel esclarece em que medida a ação pode ser objeto de plena representação artística. Evidentemente, não se trata de narrar todo e qualquer fato relativo à existência empírica do indivíduo, mesmo porque as condições dos acontecimentos podem se estender a uma distância infinitamente remota. Cervantes, por exemplo, conta a história de Dom Quixote só a partir do momento em que ele decide abraçar a cavalaria andante, e não desde o dia de seu nascimento, ou do nascimento de seus pais, seus avós etc. Cumpre ao escritor selecionar as contingências em que a essência do caráter sai da noite da possibilidade para a verdade da vida.

O conjunto das circunstâncias da vida, dos atos, dos destinos são sem dúvida o que formam o indivíduo, mas sua própria natureza, o verdadeiro núcleo de sua mentalidade e capacidade, surge independentemente disso numa grande situação e ação, em cujo decurso se descobre o que ele é, ao passo que antes desta grande situação e ação, ele apenas era conhecido segundo seu nome e sua exterioridade. ${ }^{170}$

\footnotetext{
${ }^{169}$ A propósito deste problema, remeto o leitor ao $\S 6^{\circ}$ do item I, C) Literatura e experiência da consciência.

${ }^{170}$ HEGEL, G. F., Cursos de Estética I, Terceiro Capítulo, B, II, 3 - “A ação”, p. 225. Tradução de Marco Aurélio Werle.
} 
Ao fazer da ação objeto de representação, a literatura começa a expandir o conceito de objeto para além do senso comum. A filosofia da natureza fornecera à ciência o conceito de objeto como amálgama de matéria bruta, ou, no apogeu da sofisticação kantiana, como produto da síntese do múltiplo pela percepção. Para a literatura, porém, a essência se torna objeto enquanto processo singular determinado. A literatura apresenta a figura empírica, recortada da substância pelo entendimento, como objeto conceitual - aquele que exterioriza em si e para si a essência absoluta. Eis por que ela questiona o padrão de racionalidade vigente, despertando a ciência para a necessidade de conceber o homem como sujeito concreto, ao invés de cobaia para testes de hipóteses e imputações analíticas.

Claro está que a evocação fenomenológica não se reporta a qualquer procedimento literário. Afinal, se o caráter do indivíduo não pode ser deduzido do universal, mantém-se no plano da existência formal o enredo que se resuma a coaduná-lo com uma descrição do estado do mundo. Hegel se volta para exemplos de ação literária que efetivamente satisfaçam as exigências de determinação da singularidade. Assim, no capítulo da Fenomenologia sobre a efetivação da consciência-de-si racional através de si mesma, segundo Hyppolite, deparamo-nos com "utilizações muito precisas de obras contemporâneas de Hegel: Os bandoleiros de Schiller, o Fausto de Goethe ou obras particularmente apreciadas pelos românticos, como o Dom Quixote de Cervantes" ${ }^{171}$. Mas o que há de comum entre elas? Não por acaso, são obras que perfilam o desenvolvimento da individualidade pelos momentos de exteriorização negativa. Suas personagens enfrentam crises deflagradas pela contrafação dos projetos em que se engajaram. Movidas pelo desejo de autonomia, precipitam-se a um fazer completamente exterior, que perde, na determinidade, o embasamento de suas próprias consciências. Segundo Hegel, o impacto causado sobre o indivíduo pela percepção da impossibilidade objetiva de erigir a falsa infinitude em verdadeiro Eu constitui o fulcro da colisão estética:

$\mathrm{O}$ antagonismo entre a consciência e intenção no ato e a consciência subseqüente daquilo que o ato era em si constitui aqui o fundamento do conflito. ${ }^{172}$

\footnotetext{
${ }^{171}$ HYPPOLITE, Jean. Gênese e Estrutura da Fenomenologia do Espírito de Hegel, p. 52.

${ }^{172}$ HEGEL, G. F., Cursos de Estética I, Terceiro Capítulo, B, II, 2, c - "A colisão", p. 220. Tradução de Marco Aurélio Werle.
} 
Vimos que Hegel considera a exteriorização negativa a verdadeira via de determinação da essência absoluta da individualidade. Agora justificamos a natureza estética dessa forma de exteriorização. Junto com a consciência, o indivíduo implementa a mediação infinita que o prende ao universal e que se faz sentir no ato como efetividade condicionante do ser singular. "O ato é isto: mover o imóvel, e produzir o que antes só estava encerrado na possibilidade; e com isso, unir o inconsciente ao consciente, o nãoessente ao ser." 173 Mas o inconsciente não costuma ser bem recebido no reino da efetividade. $\mathrm{O}$ absoluto se manifesta para a consciência-de-Si como uma fatalidade irracional que não se deixa absorver imediatamente pelo entendimento. O choque de realidade impele a consciência a uma cisão entre a pura negação de seu conceito e o conceito exposto pela obra de sua vida. Drama é a consubstanciação desavisada deste dilaceramento para o indivíduo. Às expensas de desespero humano, a figura do incógnito se dissolve em mais matéria de reflexão a cada ato que acrescenta verdade à experiência do sujeito. "Nessa verdade, o ato surge assim à luz do dia - como algo em que está unido um elemento consciente a um inconsciente, o próprio a um estranho: como essência dividida; a consciência the experimenta o outro lado, e o experimenta também como lado seu, mas como potência violada por ela e provocada de modo hostil." ${ }^{174}$ A experiência traz à consciência o elemento passivo da potência absoluta e atira o indivíduo a um conflito com a identidade do seu próprio Eu. Em oposição à efetividade, o elemento negado à realização perde ascendência sobre a substância do caráter. Assim, ao desdobrar o cotejo interior das alternativas particulares que um indivíduo se propõe para o dilema da exteriorização - ser ou não ser? - a literatura extrai conteúdo universal do desenvolvimento da essência, desde que se decida pela execução da potência absoluta como colisão estética, recusando o procedimento de predicação do sujeito por identidade com a substância e mostrando como a cisão de caráter determinada pela exteriorização negativa não pode encontrar resolução no dualismo da consciência formal.

Há muito os comentadores de Hegel têm apontado a presença de alusões literárias na Fenomenologia do Espírito. Rosenzweig assinala a mais proeminente de todas elas, a propósito dos capítulos sobre ação ética. "O conflito entre a lei divina e a lei humana na

\footnotetext{
${ }^{173}$ Id., Fenomenologia do Espírito, VI, A, b - "A ação ética. O saber humano e o divino, a culpa e o destino", p. 325 (347).

${ }^{174}$ Ibid., p. 325 (347-348).
} 
Antígona de Sófocles é retomado nestes desenvolvimentos com uma arte tão consumada que os traços reais da tragédia de Sófocles são dificilmente discerníveis do tecido de idéias do filósofo alemão." 175 Lukács ressalta "a importância decisiva que se atribui ao Sobrinho de Rameau de Diderot para deixar claro qual era a situação espiritual no período prérevolucionário."176 No que tange ao problema da auto-efetivação da individualidade, Hyppolite chega a afirmar que o sabor romanesco do percurso fenomenológico seria inspirado pelo Emílio de Rousseau, em cuja leitura, durante o seminário de Tübingen, Hegel "encontrara uma primeira história da consciência natural a elevar-se por si mesma até a liberdade, por meio de experiências que lhe são próprias e que são particularmente formadoras." 177 O chamado romance de formação, gênero a que também pertencem títulos como Wilhem Meister, de Goethe, e Heinrich von Ofterdingen, de Novalis, estaria na raiz da plataforma filosófica hegeliana. Porém, a despeito de inevitáveis pontos de convergência com a quadra do mundo letrado, basta descer ao pormenor das figuras, no corpo da obra, para constatar que as seletas incursões sobre a literatura não se pautam pela influência de nenhum gênero específico de composição literária. E mais do que a variedade de gêneros, a variedade de estilos mostra que a evocação fenomenológica de personagens literárias não reverbera o apanágio desta ou daquela estética em particular. Do contrário, o uso de momentos aparentemente díspares da história da arte para consubstanciar o processo de exteriorização do espírito sugere que a dissolução do fundamento transcendental da ciência deve ser preparada pelo reconhecimento da imprescindibilidade da individualidade como categoria estética universal.

a) Fausto: o prazer e a necessidade

A verdade teórica repercute primeiro ad hominem. Após haver compreendido a correta relação entre potência e ato pela crítica às distorções e insuficiências da metodologia empírica, a consciência não consegue mais ficar indiferente a sua própria autonomia. Antes de tudo, ela precisa reorganizar o seu campo de experiência conforme a sua essência, a despeito do desafio intelectual de refundar a ciência sobre outras bases.

\footnotetext{
${ }^{175}$ ROSENZWEIG, Franz, Hegel e o Estado, p. 301.

${ }^{176}$ LUKÁCS, Georg, A falsa e a verdadeira ontologia de Hegel, p. 15.

${ }^{177}$ HYPPOLITE, Jean, Gênese e Estrutura da Fenomenologia do Espírito, p. 27.
} 
Assim, no excurso sobre a "efetivação da consciência-de-si racional através de si mesma," 178 que sucede à Razão Observadora, Hegel passa ao exame de percalços enfrentados pela individualidade que se descobre senhora do próprio destino e decide atuar para conquistá-lo.

O primeiro ponto de apoio para a reflexão é nada menos do que a obra magna de Goethe, citada aparentemente de memória. Na tragédia, Fausto se apresenta como o estudioso atormentado que acabou de chegar à consciência da primazia ontológica do devir sobre todo ser originário. Muito reveladora, a propósito, é a cena em que ele se põe a traduzir o Evangelho segundo São João. Entregue à douta tarefa, Fausto endossa uma escolha bastante peculiar para verter o significado da palavra grega logos, que São Jerônimo traduzira para o latim por verbum, e Lutero, da Vulgata, por Wort:

\author{
Escrito está: "Era no início o Verbo"! \\ Começo apenas, e já me exacerbo! \\ Como hei de ao verbo dar tão alto apreço? \\ De outra interpretação careço; \\ Se o espírito me deixa esclarecido, \\ Escrito está: "No início era o Sentido!" \\ Pesa a linha inicial com calma plena, \\ Não se apressure a tua pena! \\ É o sentido então, tudo o que opera e cria? \\ Deverá opor! No início era a Energia! \\ Mas, já, enquanto assim o retifico, \\ Diz-me algo que tampouco nisso fico. \\ Do espírito me vale a direção, \\ E escrevo em paz: Era no início a Ação!
}

Geschrieben steht: "Im Anfang war das Wort!"

Hier stock' ich schon! Wer hilft mir weiter fort?

Ich kann das Wort so hoch unmöglich schätzen,

Ich muss es anders übersetzen,

Wenn ich vom Geiste recht erleuchtet bin.

Geschrieben steht: Im Anfang war der Sinn.

Bedenke wohl die erste Zeile,

Da $\beta$ deine Feder sich nicht übereile!

Ist es der Sinn, der alles wirkt und schaft?

Es sollte stehn: Im Anfang war die Kraft!

Doch, auch indem ich dieses niederschreibe,

Schon warnt mich was, dass ich dabei nicht bleibe.

Mir hilft der Geist! Auf einmal seh' ich Rat

Und schreibe getrost: Im Anfang war die Tat! ${ }^{179}$

Encerrado no estreito quarto de trabalho, exausto de serões noturnos, e exasperado com a insignificância do parco conhecimento haurido a preço de uma vida inteira enclausurada, Fausto não tem mais tempo a perder com a poeira dos livros. "Lança-se, pois, à vida, e leva à plena realização a individualidade pura na qual emerge a consciência-de-

\footnotetext{
${ }^{178}$ HEGEL, G. W. F., Fenomenologia do Espírito, V, B - "A efetivação da consciência-de-si racional através de si mesma", p. 249 (263).

${ }^{179}$ GOETHE, J. W., Fausto, cena "Quarto de Trabalho", p. 131. Tradução de Jenny Klabin Segall.
} 
si." ${ }^{180}$ Só então os verdadeiros problemas começam. A profissão de fé na primazia do devir não garante o sucesso da empreitada. A cautela nunca foi suficiente para saltar o abismo que separa a teoria da prática, em cuja beira o homem se sujeita ao sopro da provocação mefistofélica: “- Almejas voar e não te sentes livre da vertigem?" 181

A experiência deixará claro o que há de errado com a perspectiva faustiana, mas Hegel nos antecipa a razão da tragédia. A consciência gerada na privação do prazer tende a conceber a ação como gozo empírico da singularidade. "Mais do que produzir para si sua felicidade, imediatamente a colhe e desfruta. As sombras da ciência, das leis e dos princípios que se interpõem entre ela e a sua própria efetividade, desvanecem como névoa sem-vida, incapaz de acolher a consciência-de-si com a certeza de sua realidade. Ela então toma a vida como se colhe um fruto maduro; e que, do modo como se oferece à mão, essa o agarra." ${ }^{182}$ Entretanto, o exercício da autonomia tem pouco a ver com fruição, deleite e espontaneidade. Como vimos, a auto-efetivação do caráter, que distingue a singularidade, consiste na exteriorização da essência por oposição à efetividade. "Na determinação de ser, para si, a essência como algo para-si-essente, a consciência-de-si é a negatividade do Outro." ${ }^{183}$ E a Fausto ainda falta experimentar essa negatividade dolorosa do devir.

Referindo-se a este estágio de consciência, cujo conceito de autonomia consiste em entregar-se ao fluxo da efetividade, Hegel o diz imbuído pelo "espírito da terra [Erdgeist]." ${ }^{184} \mathrm{O}$ conceito hegeliano de espírito se funde com alusão à cena em que Fausto recita o rito de invocação do elemental da terra, e a criatura abrutalhada surge do chão, em meio a labaredas, para atender ao chamado do homem que renegou a reflexão na esperança de conhecer a vida:

FAUSTO

Fugir-te, eu, flâmeo vulto? Qual!

Sou eu, Fausto, o teu igual!

\section{FAUST}

Soll ich dir, Flammenbildung, weichen?

Ich bin's, bin Faust, bin deinesgleichen!

\footnotetext{
${ }^{180}$ HEGEL, G. W. F., Fenomenologia do Espírito, V, B - “A efetivação da consciência-de-si racional através de si mesma", p. 256 (271).

${ }^{181}$ GOETHE, J. W., Fausto, "Dia Sombrio - Campo", p. 493. Tradução de Jenny Klabin Segall.

${ }^{182}$ HEGEL, G. W. F., Fenomenologia do Espírito, V, B, a - "O prazer e a necessidade”, p. 257 (271).

${ }^{183}$ Ibid., p. 255 (271).

${ }^{184}$ Ibid., p. $256(270)$.
} 


\section{GÊNIO DA TERRA}

No ardor da ação, no afã da vida,

Fluo, ondulo, urdo, ligo,

Cá e lá, a tramar,

Berço e jazigo,

Perene mar,

Urdidura alternante,

Vida flamante,

Do Tempo assim movo o tear milenário,

E da Divindade urdo o vivo vestuário.

\section{FAUSTO}

$\mathrm{Tu}$, que o infinito mundo rondas,

Gênio da Ação, sinto-me um só contigo!

\section{GÊNIO}

És um, com o gênio que em ti sondas, mas não comigo!

\section{ERDGEIST}

In Lebensfluten, im Tatensturm

Wall' ich auf und ab,

Webe hin und her!

Geburt und Grab,

Ein ewiges Meer,

Ein wechselnd Leben,

Ein glühend Leben,

So schaff' ich am sausenden Webstuhl der Zeit

Und wirke der Gottheit lebendiges Kleid.

\section{FAUST}

Der du die weite Welt umschweifst,

Geschäftiger Geist, wie nah fühl' ich mich dir!

\section{GEIST}

Du gleichst dem Geist, den du begreifst,

Nicht mir! ${ }^{185}$

Uma vez abandonado pelo Gênio da Terra, Fausto logo vem a encontrar a entidade disposta a assessorá-lo. Apesar de alguma relutância, firma com ela o pacto maligno. Em troca de sua alma, o príncipe das trevas promete conduzi-lo à ação sob signo do prazer:

\section{MEFISTÓFELES}

Daquilo que aos sentidos praz, Numa hora, mais desfrutarás

Do que, em geral, num ano inteiro.

Dos meigos gênios os cantares,

Os lindos quadros que diluem nos ares,

Não são mendaz, mágica folga.

O teu olfato há de se deliciar,

Distrai-se, após, teu paladar,

E teu sentir, enfim, se empolga.

O prólogo sem mais abstrai,

Estamos juntos, principiai!

\section{MEPHISTOPHELES}

Du wirst, mein Freund, für deine Sinnen

In dieser Stunde mehr gewinnen

Als in des Jahres Einerlei.

Was dir die zarten Geister singen,

Die schönen Bilder, die sie bringen,

Sind nicht ein leeres Zauberspiel.

Auch dein Geruch wird sich ergetzen,

Dann wirst du deinem Gaumen letzen,

Und dann entückt sich dein Gefühl.

Bereitung braucht es nicht voran,

Beisammen sind wir, fanget an! $!^{186}$

${ }^{185}$ Ibid., "Noite", p. 65.

${ }^{186}$ Ibid., "Quarto de Trabalho", p. 149. 
Que não se ponha sub judice a boa fé de Mefistófeles. Nenhuma cláusula fica em letras miúdas. Embora nunca cesse de sentir-se dividido entre o céu e a terra, o sagrado e o profano, a razão e a sensibilidade, Fausto sabe exatamente o que pretende por meio desta parceria. O pacto sela a aposta na busca do prazer como forma genérica de realização.

De resto, o enredo da tragédia é conhecido. Mefistófeles mete o alquebrado doutor na Cozinha da Bruxa, a qual he prepara uma poção de rejuvenescimento. Com sangue quente correndo novamente pelas veias, Fausto cria coragem para cortejar Gretchen, a pequena donzela que cruza seu caminho. À mocinha modesta, ele oferece jóias de princesa. Interpela-a pelas ruas. E depois de impressioná-la com vasta ilustração, esquivando-se da acusação de ateísmo, propõe-lhe um meio de burlar a incômoda vigilância da mãe. Bastaria pingar algumas gotas de sonífero em sua janta para que o quarto da casa ficasse à disposição dos dois até a manhã seguinte. A paixão cresce no coração de Gretchen. Ela já não se sente no direito de recriminar a amiga que cedeu às tentações da carne. Sua vontade é aderir ao plano. Então Fausto lhe entrega um frasco do elixir letárgico. Mas ao invés de despertar pela manhã, a mãe de Gretchen sucumbe silenciosamente ao sono eterno. Órfã, corroída pelo remorso, a menina ainda se descobre grávida. O soldado Valentim se apressa a cobrar explicações do sedutor que lhe desonrou a irmã. Encontra-o em companhia do providente aliado, a quem se atraca primeiro. No combate, Fausto o fere de morte com uma estocada certeira. Valentim expira nos braços da irmã desesperada, não sem antes lhe vaticinar um futuro de miséria sob o manto negro do meretrício. Sozinha, desamparada e hostilizada por toda parte, a começar pela igreja, Gretchen afoga na fonte o filho recémnascido. O tribunal a condena ao patíbulo por infanticídio. Enquanto ela aguarda no cárcere a execução da sentença, Fausto segue viagem com Mefistófeles para a Noite de Valpurgis, uma espécie de bacanal satânico que congrega bruxas, duendes, almas penadas, animais falantes e outros seres réprobos, no alto de uma montanha. Ali, a fruição da vida se despe de quaisquer adornos de aspiração virtuosa e toca as raias do grotesco.

Cada um remexe-se, estrebucha,

Faz o melhor que pode.

Pula o corcunda, arfa a gorducha,

Sem que a aparência os incomode.
Wie jeder doch die Beine lupft!

Sich, wie er kann, herauszieht!

Der Krumme springt, der Plumpe hupft

Und fragt nicht, wie es aussieht. ${ }^{187}$

\footnotetext{
${ }^{187}$ Ibid., "Sonho da Noite de Valpurgis", p. 483.
} 
Fausto cai perplexo ao tomar conhecimento da condenação de Gretchen. “ - E uma ilusão de amor, eis o seu crime!"188 Ele ainda tentaria sacá-la da masmorra, onde a surpreende em pleno delírio. Porém, impassível à afobação de Fausto com a iminência dos guardas, Gretchen se recusa a fugir depois de sentir frieza no beijo do amado. Está feito o estrago - e com ele, uma das cenas mais comoventes da literatura universal.

A Hegel interessa o exame de consciência a que essa experiência conduz. " $O$ indivíduo experimenta o duplo sentido subjacente no que fazia; isto é: ter se apropriado de sua vida [sein Leben sich genommen zu haben]; ele apanhou a vida, mas o que encontrou foi, antes, a morte." 189 Diante do desfecho da aventura, não admira que Fausto venha a questionar o próprio caráter. Mas ele ainda não está preparado para conceber que a efetividade dos meios aniquilou os fins, que a morte foi o modo de realização do ideal de vida almejado. Ele sai da ação completamente desconcertado pela "contradição entre o que para ele era a essência, e o que a essência é em si." ${ }^{190}$ Essa contradição não pode ser absorvida por uma consciência que resguarda o ideal acima da negatividade. "A passagem do momento desse seu fim ao momento de sua essência verdadeira é para ela um puro salto no oposto, pois esses momentos não estão contidos e ligados no sentimento [Gefühle], mas só no puro Si, que é um universal ou o pensar." ${ }^{191}$ Apesar de haver conhecido o oposto na intuição sensível, o sujeito continua com a certeza de ser uma substância de categorias indeterminadas. "O que se torna, pois, no prazer desfrutado, objeto da consciência-de-si como sua essência, é a expansão dessas essencialidades vazias - da pura unidade, da pura diferença e da sua relação." 192

Para Fausto, a primeira figura da individualidade, o negativo ainda não tem a forma da efetividade. E quando a consciência-de-si se fecha para sua essência positiva, "a essência negativa vazia a defronta e é a potência que a devora."193 Ao invés de uma ação autônoma, fundamentada sobre si mesma, a exteriorização desse "círculo de abstrações"194 se realiza como devir de uma imposição absoluta. "É o que se chama necessidade; com efeito, necessidade, destino etc., são justamente uma coisa que ninguém sabe dizer o que

\footnotetext{
${ }^{188}$ Ibid., "Cárcere", p. 503.

${ }^{189}$ HEGEL, G. W. F., Fenomenologia do Espírito, V, B, a - “O prazer e a necessidade”, p. 259 (273-274).

${ }^{190}$ Ibid., p. 259 (274).

${ }^{191}$ Ibid., p. 259 (274).

${ }^{192}$ Ibid., p. 258 (273).

193 Ibid., p. 258 (272).

${ }^{194}$ Ibid., p. 258 (272).
} 
faz, quais suas leis determinadas e seu conteúdo positivo." ${ }^{195}$ Em suma, aquele que se julgava senhor de si termina soterrado pela avalanche da fortuna. O princípio da busca do prazer se revela fundamentado na mais absoluta ausência de liberdade - logo, ele não pode valer por uma ética.

ß) Karl von Moor: a lei do coração e o delírio da presunção

Daí não se depreenda que a tragédia foi inútil. Fausto abandonou a teoria em nome da experiência do prazer. Mas o malogro do gozo particularista devolve à consciência a certeza de que a ação verdadeiramente autônoma deve ser fundamentada no universal. Além disso, depois de Fausto, a consciência sabe que as suas intenções não são imunes à negatividade e que a sua ação sofre uma resistência contrária à disposição anímica.

O problema continua a ser como o universal pode servir de fundamento para exercício da autonomia. Kant postulara o princípio supremo e Fichte o abreviou à figura do Eu. Fausto conheceu o conteúdo dessas categorias abstratas sob a forma de "uma necessidade atroz pela qual a individualidade é oprimida." 196 A segunda figura da individualidade, que continua o percurso fenomenológico, embora não possua, em sua consciência-de-si, a memória da experiência anterior, já nasce marcada pela percepção de um antagonismo com a potência absoluta. Para ela, a forma da efetividade é o peso da necessidade. Por não haver ainda dado a essa forma nenhum conteúdo positivo, sua consciência do negativo se resume à irrealização do ideal. O jovem coração subjugado sente que seu projeto de autonomia está vetado pelo estado do mundo. "Então a consciência denuncia a ordem universal como uma perversão da lei do coração e da sua felicidade. Perversão inventada e exercida por sacerdotes fanáticos, por tiranos devassos com a ajuda de seus serviçais, que humilhando e oprimindo procuram ressarcir-se de sua própria humilhação."197

\footnotetext{
${ }^{195}$ Ibid., p. 258 (273).

${ }^{196}$ Id., Fenomenologia do Espírito, V, B, b - "A lei do coração e o delírio da presunção", p. 261 (275-276).

${ }^{197}$ Ibid., p. 265 (280-281).
} 
Desta vez, o enredo da experiência recebe as tintas d' Os Bandoleiros, marco inaugural da carreira literária de Friedrich Schiller. A rebeldia de um "alto desígnio"198 contra as imposições da ordem estabelecida, a recusa insidiosa a uma vida regida por necessidades estranhas, o ímpeto de seguir somente a própria lei, a lei do coração, e a convicção de que o princípio de autonomia deve vigorar universalmente sobre a terra, para o "bem da humanidade", ${ }^{199}$ indicam-nos quem, por ora, tem nas mãos o ato do espírito: Karl von Moor, protagonista da peça, remói a pretensão de reformar o estado do mundo à luz da excelência de caráter. Ouçamos sua voz:

Me enojo deste século borrado de tinta quando leio meu Plutarco sobre os
grandes homens.

Suas primeiras palavras já dão o tom de uma alma desabituada a lisonjas. Ele depõe a obra clássica de Plutarco sobre a mesa da taverna, um compêndio de biografias de generais e estadistas gregos e romanos. A tenacidade da queixa não se deixa amolecer pelos vapores do vinho.

Arre! Pago com asco os feitos deste frouxo século de castrados, que não fez mais que ruminar as glórias de antanho e arruinar com seus comentários, estropiar com suas peças trágicas os heróis da Antigüidade. ${ }^{201}$

A peça Os Bandoleiros foi publicada originalmente em 1781, quando Schiller contava 22 anos. Calcula-se que ele a tenha escrito ao longo dos quatro anos anteriores, enquanto se formava na Academia Militar, sob a disciplina despótica do Duque de Württemberg. A pouca idade não o impediu de escrever sobre o passado: o tempo da ação dramática, delimitado em dois anos na folha de rosto, compreende período ligeiramente anterior ao nascimento do autor. Escassas referências, dispersas ao longo do texto, permitem concluir que a ação transcorre durante a Guerra dos Sete Anos (1756-1763). Na

${ }^{198}$ Ibid., p. 261 (276).

${ }^{199}$ Ibid., p. 261 (276).

${ }^{200}$ SCHILLER, Friedrich von, Die Räuber, Phillip Reclam, Stuttgart, 1992, p.19 (Tradução minha).

Mir ekelt vor diesem tintenklecksenden Säkulum, wenn ich meinem Plutarch lese von großen Menschen.

${ }^{201}$ SCHILLER, F., Os Bandoleiros, p. 30. 
primeira cena do segundo ato é mencionada a Batalha de Praga, ocorrida em maio de 1757, como sendo um evento recente. ${ }^{202}$

A Alemanha de Schiller jazia esfacelada em centenas de reinos, ducados, principados, baronatos, cidadelas e prelazias, onde a servidão camponesa vicejava vergonhosamente, e os "pobres poetas (...) não tinham sequer um mísero sapato para usar, por terem dado o único par que possuíam à feitura de um livro." ${ }^{203}$ Conforme crescia a desvantagem dos potentados alemães frente aos grandes estados nacionais europeus, o Império Austríaco e o Reino da Prússia passaram a se rivalizar pela capitania da unificação política. Quando Inglaterra e França entram em guerra devido a conflitos de colonos pelo controle de possessões territoriais na América, a Prússia se alia aos ingleses e invade a Saxônia, no domínio austríaco. Começa a Guerra dos Sete Anos.

Sabemos, portanto, que as ganas de Moor se deblateram contra uma conjuntura avessa ao exercício da autonomia. "Essa ordem divina e humana, que encontrou vigente, a consciência a tomou por uma efetividade morta." ${ }^{204}$ Na taverna, Spiegelberg expõe aos camaradas o impasse da juventude agrilhoada perante as portas da vida. Sob premência de colher alternativas de um quadro geral de sujeição, nenhuma escolha particular parece efetivar a liberdade.

Escolha? O quê? Não tendes nada a escolher! Quereis ser atirados à torre da
prisão e passar fome até virardes nada, esperando que toquem as trombetas do
juízo final? Quereis esfalfar-vos e sofrer no cabo de uma pá ou de um enxadão só
para conseguir um pedacinho de pão seco? Quereis mendigar um almoço magro à
janela das pessoas no papel de um cantor ambulante? Ou quereis vestir coturnos -
e aí a pergunta restringe-se ao fato poder ou não confiar em vós - e ir até lá
embaixo lamber as botas e o humor hipocondríaco de um cabo de esquadra local?
Ou talvez dançar segundo a musiquinha do tambor militar com o rabo entre as
pernas? Ou talvez ainda remar nas galeras sentindo o peso de um navio inteiro

\footnotetext{
${ }^{202}$ A demarcação do tempo histórico da ação parece ter sido uma das principais preocupações da segunda edição da peça, que se tornou também bastante difundida. Nessa edição, feita sem a participação de Schiller, alguns diálogos do primeiro ato foram modificados com a inserção de comentários sobre o recente término da guerra e a celebração da paz na Alemanha, e a menção à Batalha de Praga foi substituída por alusão mais genérica a uma luta na Hungria. A segunda edição ainda suprimiu trechos, trocou a ordem de algumas cenas, permutou ou condensou falas de personagens secundárias e diminuiu a extensão dos monólogos. Ao que tudo indica, trata-se de uma adaptação do original, concebida para a encenação, que ainda hoje é publicada sem ressalvas como autêntico texto schilleriano.

${ }^{203}$ Ibid., p. 109.

${ }^{204}$ HEGEL, G. W. F., Fenomenologia do Espírito, V, B, b - “A lei do coração e o delírio da presunção”, p. 264 (279).
} 
pender de vossos braços? Vede, são estas vossas escolhas... Aí estão todas as vossas opções! $!^{205}$

Vagueando pela noite da possibilidade, Moor se ressente de que os seus talentos jamais venham a encontrar aplicação auspiciosa. Ao contrário dos gigantes imortalizados por Plutarco, ele terá de se esgueirar como um verme pelas tripas da burocracia. E tudo por "um punhado de ducados piolhentos". ${ }^{206}$ Conjectura insuportável para quem não se cansa de censurar a falta de caráter alheia e se recrimina a cada vez que concede um aperto de mão. Fausto não perdeu a virtude por pactuar com o demônio? Então, nada de conciliações! Transigere est alienare. Moor se retrai na pureza de caráter, o extremo oposto do espírito. Ele parte para o enfrentamento do mal sem consentir com as regras do jogo. "Ora, como essa despótica ordem divina e humana está separada do coração, é para este uma aparência, que ainda deve perder o que lhe está associado; a saber, o poder e a efetividade."207 O ideal de autonomia é tão completamente negado pela realidade que qualquer forma de exteriorização vislumbrada pelo indivíduo requer a implosão universal do estado de coisas para se efetivar a contento.

Não, não me agrada pensar nisto. Será que sou obrigado a deixar o meu corpo sofrer dentro de um espartilho apertado e ajustar minhas vontades ao colete da lei? A lei deteriorou em passos de lesma aquilo que deveria ser o vôo da águia. A lei não deu ao mundo nenhum homem de grandeza, mas a liberdade incuba e faz nascer colossos extremados. E as duas, lei e liberdade, fazem paliçadas uma à outra no ventre dos tiranos, cortejam o humor de seu estômago e deixam-se entalar em suas roldanas... Ah, se o espírito de Herrmann ${ }^{208}$ ainda ardesse sob as cinzas! Imagino uma tropa de sujeitos como eu, e penso que da Alemanha deve surgir uma República perante a qual Roma e Esparta não sejam mais do que conventos de freiras... ${ }^{209}$

\footnotetext{
${ }^{205}$ SCHILLER, F., Os Bandoleiros, p. 44.

${ }^{206}$ Ibid., p. 31. Ducados: designação da moeda corrente.

${ }^{207}$ HEGEL, G. W. F., op. cit., p. 262 (276-277).

${ }^{208}$ Herrmann ou Armínio (16 a.C. - 21 d.C.): rei dos antigos germanos, que liderou a expulsão dos exércitos de Roma para fora do território alemão, na Batalha de Teutoburgo, em 9 a.C..

${ }^{209}$ SCHILLER, F., op. cit., p. 31. No original:
}

Nein, ich mag nicht daran denken. Ich soll meinen Leib pressen in eine Schnürbrust und meinen Willen scnüren in Gesetze. Das Gesetz hat zum Schneckengang verdorben, was Adlerflug geworden wäre. Das Gesetz hat noch keinen großen Mann gebildet, aber die Freiheit brütet Kolosse und Extremitäten aus. Sie verpalisadieren sich ins Bauchfell eines Tyrannen, hofieren der Laune seines Magens und lassen sich klemmen von seinen Winden. - Ah! da $\beta$ der Geist Hermmanns noch in der Asche glimmte! - Stelle mich vor ein Heer Kerls wie ich, gegen die Rom und Sparta Nonnenklöster sein sollen. (Er wirft den Degen auf den Tisch und steht auf.) (SCHILLER, Friedrich von, Die Räuber, Phillip Reclam, Stuttgart, 1992, p. 20) 
Se esperasse até uma década depois da publicação d'Os Bandoleiros, no curso da Revolução Francesa de 1789, Moor ainda haveria de encontrar sua tropa. Não é segredo que essa mesma reverência por arquétipos ancestrais embasava a plataforma política do jacobinismo francês. Rousseau e Montesquieu haviam concebido o governo democrático a partir da experiência greco-latina. Na tribuna da Convenção, em 1793, os discursos de Saint-Just e Robespierre apregoavam a restauração da república antiga contra a decadência moral do mundo moderno.

Oh, se eu pudesse campear natureza afora, soprando as trombetas do motim, a ${ }_{210}$ de que ar, terra e mar voltassem a conduzir essa cria de hienas a se encontrar!

Saint-Just, o arcanjo do Terror, elegeu-se deputado da Convenção aos 24 anos de idade. A Moor, o curso do mundo não ofereceria um palco assim tão bem iluminado. Ao invés de saltar para o centro, ele correrá para as margens; ao invés de outorgar a lei, infringi-la-á. Na falta de uma revolução, "a efetivação da essência imediata indisciplinada vale como apresentação de uma excelência do indivíduo e como a produção do bem da humanidade." 211 O que não exclui uma boa dose de desprezo por essa cria de hienas.

A decepção de Moor com a raça humana agora se acresce de um motivo bastante preciso: em resposta por escrito, ele acaba de ser renegado pelo pai, a quem recorrera via cartas de arrependimento. Nestas suplicava auxílio para se reerguer da vida dissoluta em que consumira os anos de estudante. A repulsa pelos ambientes acadêmicos, infestados de tísicos contemplativos, convertera-o num freguês de tavernas e alcovas, onde se amontoavam os desajustados, e ele topava com pares em rudeza de maneiras, mas não em paixões e propósitos. Levado pelas melhores qualidades ao lodo da inadequação, Moor planejara regressar ao castelo da família. Lá o esperava a bela Amália von Edelreich com uma promessa de futuro. Porém, se agora nem mesmo o coração paterno se revela capaz de perdoar e amar, se até as portas do lar se fecham para ele como que para um feroz inimigo, então nenhuma esperança lhe resta o mundo, nem nunca qualquer outro sentimento recíproco poderá germinar. "Por conseguinte, o indivíduo, como antes abominava somente a lei rígida, agora acha os corações dos próprios homens, contrários a suas excelentes

\footnotetext{
${ }^{210}$ Ibid., p. 52.

${ }^{211}$ HEGEL, G. W. F., op. cit., p. 261 (276).
} 
intenções e dignos de abominação." ${ }^{212}$ Eis que nasce o bandoleiro Moor, chefe de regimento por aclamação, sob a chuva de chapéus de meia dúzia de comparsas.

\begin{abstract}
Meu espírito está sedento de feitos, meu fôlego necessita de liberdade... Assassinos, bandoleiros! Com essas palavras jogo a lei aos meus pés... Homens esconderam a humanidade aos meus olhos quando eu apelei por humanidade... Basta, portanto, de simpatia, chega de ser humano e poupá-los! $!^{213}$
\end{abstract}

Karl ainda viria a descobrir que a carta de repúdio era uma falsificação, fabricada pelo seu próprio irmão, Franz von Moor, que o invejava desde a infância, e pretendia que o pai o deserdasse do nome, das glórias e das posses da família. Mas já era tarde demais. O juramento de fidelidade ao bando é irrevogável. E o desmascaramento do vilão não remove as cicatrizes da clandestinidade. Doravante, a individualidade será flagrada por Hegel na contradição entre a pureza e a perversão do caráter.

A oscilação entre extremos já está inscrita no conceito que fundamenta o antagonismo da consciência com o estado do mundo. "De um lado, pois, essa efetividade é uma lei, pela qual a individualidade singular é oprimida: uma violenta ordem do mundo, que contradiz a lei do coração. De outro lado, é uma humanidade padecente sob essa ordem, que não segue a lei do coração, mas está submetida a uma necessidade estranha."214 A experiência mostrará que a consciência não pode suprimir essa duplicidade do seu objeto por meio de uma ação direta.

O bandoleiro Razzman profere testemunho de como o comandante Moor pretende atribuir sentido ao banditismo:

\footnotetext{
Ele não assassina para roubar, como nós... Parece que nem se interessa mais pelo dinheiro, embora pudesse tê-lo na quantia que quisesse. Até mesmo a terceira parte do botim, que por direito lhe pertence, ele manda distribuir aos órfãos ou os investe no estudo de algumas crianças de futuro... Mas se lhe cai às garras um proprietário de terras, que trata seus empregados como animais, ou se vem a esfolar um canalha com botões e ombreiras de ouro, que vive de falsificar as leis e de tapar o olho da justiça, ou qualquer outra criatura do tipo... Cara! Aí ele se sente bem e bate e esbofeteia como se fosse o diabo, como se em todas as suas fibras morassem uma das Fúrias... ${ }^{215}$
}

\footnotetext{
${ }^{212}$ Ibid., p. 263 (278).

${ }^{213}$ SCHILLER, F., op. cit., p. 53.

${ }^{214}$ HEGEL, G. W. F., op. cit., p. 261 (275).

${ }^{215}$ SCHILLER, F., op. cit., p. 98.
} 
A renúncia aos proventos materiais do crime é uma tentativa de restabelecer, no interior da consciência, a separação formal entre a intenção teórica e o objeto da vontade prática. Como se o crime fosse praticado com uma finalidade que não se realiza no ato consumado. E assim Moor supõe se distinguir de um ladrão comum. Purgando-se do gozo empírico e do interesse particular, a consciência retrocede da sua essência positiva para a certeza da pureza de caráter, da integridade de princípios: a certeza de que sua identidade repousa eternamente na excelência de ideais sólidos e incorruptíveis - a Liberdade, a Igualdade, a Justiça. "Porém, no resultado da experiência que se revelou aqui, a consciência na sua lei está cônscia de si mesma, como este Efetivo; e, ao mesmo tempo, tornou-se cônscia de sua inefetividade, enquanto consciência-de-si, enquanto efetividade absoluta, porque essa mesma essencialidade, essa mesma efetividade se lhe alienou [entfremdet]."216 Apesar do esforço ascético para reafirmar sua identidade originária, quando retorna da experiência para o interior, a consciência já não é mais a mesma, e no fundo não se reconhece como antes. Perdido em solilóquios pelas florestas da Boêmia, o bandoleiro Moor sofre com a maldição de Lady Macbeth, que jamais deixaria de enxergar as mãos sujas de sangue, não importa quanto as lavasse. Ele nem se identifica com seus atos, nem pode fugir de si mesmo, preso na altercação infinita entre a certeza e a verdade do caráter. "Ou seja: os dois lados, segundo sua contradição, valem imediatamente como sua essência para essa consciência - que, portanto, está desvairada no seu mais íntimo."217

Hegel insiste no tema do desvario como sintoma da degeneração de caráter. A consciência tende a entrar em colapso caso se obstine em validar o ato singular com um fundamento universal que se exterioriza negativamente, mas não para ela. "Se algo é de fato efetivo ou essencial para a consciência, em geral, mas não o é para mim, então, na consciência de seu nada, eu - já que sou a consciência geral - tenho ao mesmo tempo a consciência de sua efetividade; ora, quando os dois [momentos] são fixados, isso forma uma unidade que é o desvario em geral. ${ }^{, 218}$ A bipolaridade de caráter sinaliza que a lei do coração não se presta a efetuar uma passagem coerente da teoria à prática. A profissão de fé na substância ética logra estabelecer uma conciliação meramente formal do ideal de autonomia com a realidade. O resultado é um padrão de moralidade em que todo e qualquer

\footnotetext{
${ }^{216}$ HEGEL, G. W. F., op. cit, p. 265 (280).

${ }^{217}$ Ibid., p. 265 (280).

${ }^{218}$ Ibid., p. 265 (280).
} 
ato está justificado a priori. Porém, com o acúmulo de experiência, o mau infinito começa a pesar sobre os ombros. Incapaz de determinar um critério inequívoco de conduta, a individualidade passa a agir em estado de delírio. A prática se torna, para ela, um terreno confuso e hostil, onde a irrealização positiva do ideal precisa ser justificada à força, sob um fundamento cada vez mais vazio. "O pulsar do coração pelo bem da humanidade desanda assim na fúria de uma presunção desvairada; no furor da consciência para preservar-se de sua destruição. Isso porque ela projeta fora de si a perversão que é ela mesma, e se esforça por considerá-la e exprimi-la como um Outro." ${ }^{, 19}$ Quem será o bode expiatório?

Quando se trata de efetivar um ideal absoluto, a culpa pelo estranhamento na consciência-de-si pode recair sobre qualquer objeto que sirva para consumar o ato. Eis por que Moor resolve assassinar sumariamente o advogado do conde de Regensburg, ao ser informado de que ele "estaria movendo", com sua "manha", "um processo de um milhão contra o governo". Indignado, Moor prepara uma emboscada à carruagem em que viajavam o advogado e o conde, como conta o bandoleiro Razzman.

\begin{abstract}
Tinhas de ver o homem naquele instante! Se adiantou a nós e saltou sobre o coche, com duas tercerolas na mão! E o tom da voz a gritar: Alto! O cocheiro, que não queria parar, praticamente voou do assento; o conde atirou de dentro do coche, sem direção, os cavaleiros sumiram... Ele estava furioso como um touro sob o cutelo... És tu, pois, o rufião que quer fazer da justiça uma prostituta vendida? $\mathrm{O}$ advogado tremia tanto a ponto de bater os dentes... e o punhal entrou em sua barriga como um esteio no campo da vinha... Eu fiz a minha parte!, ele gritou, e se afastou de nós, orgulhoso. O saque é coisa vossa! E ao dizer isso sumiu na floresta... ${ }^{220}$
\end{abstract}

Assim, a renúncia ao gozo empírico, ao locupletamento, revela-se apenas a manifestação mais branda de um ascetismo que, no auge da repugnância pelo próprio estado de determinação, chega a perpetrar o sacrifício absoluto da singularidade. "Em seu desvario, a consciência denuncia a individualidade como fonte de seu desvario e perversão; mas uma individualidade alheia e contingente. Porém o coração, ou seja, a singularidade que pretende ser imediatamente universal - da consciência, é a fonte mesma desse desvario e perversão. Seu agir só tem por resultado que essa contradição chegue à sua consciência." ${ }^{221} \mathrm{Na}$ verdade, a pureza de caráter não é virtude, mas vício, pois denota que o

\footnotetext{
${ }^{219}$ Ibid., p. 265 (280).

${ }^{220}$ SCHILLER, F., op. cit., p. 99.

${ }^{221}$ HEGEL, G. W. F., op. cit., p. 265 (281).
} 
indivíduo não se distingue do universal e por isso não consegue aceder a meios de agir no próprio interesse, em prejuízo de si e dos outros, e sobretudo destes.

Moor caminha para o isolamento na medida em que sua conduta o destitui da possibilidade de se justificar para o outro à luz de um fundamento mutuamente partilhado. A partir dessa constatação, avaliando o saldo da experiência, Hegel desenvolve a idéia de que a lei do coração não é um princípio válido de autonomia porque ela não pode ser reconhecida pelas demais individualidades. As nobres intenções de reformar o estado do mundo por meio de uma ação direta devem ceder lugar à consciência de que a individualidade é a forma de efetividade do universal - de que a ação sobre o estado do mundo, por conseguinte, só atinge seu fim no seu objeto, o ser singular. Trata-se de conceber a eticidade como produto complexo da interação de todos os indivíduos, ao invés de simples emanação de um ato instaurador supostamente heróico.

A essência espiritual da substância ética se manifesta para a consciência quando a escalada do banditismo leva Moor a se confrontar com impactos mais amplos das ações que comanda. Dentre estas, consta o episódio do resgate do bandoleiro Roller, que fora capturado pelas autoridades e condenado à morte. Para Moor, salvá-lo da forca era questão de compromisso com o juramento de fidelidade que os coligava: a palavra de honra deve ser cumprida a qualquer custo. Assim, para abortar a execução do correligionário, que já subira ao patíbulo, ele e o resto do bando incendeiam a cidadela onde transcorria o auto de justiça. $O$ incêndio se alastra devastadoramente pelas casas, causando sofrimentos inefáveis. Uma torre de pólvora vai pelos ares. Idosos e doentes são tragados pelo fogo.

Nada que incomode o bandoleiro Schufterle, para quem "não vale a pena se dar ao trabalho de falar dessa cambada de gente", desse rebanho de conformistas que povoa a terra. E prossegue:

\footnotetext{
No meio do forrobodó, quando eu passava em frente a um barracão, ouvi um berreiro, fui ver o que era e quando vi a coisa, enfim, adivinhem o que era? Uma criança ainda fresquinha e saudável, que estava deitada no chão, embaixo da mesa, a se desmontar... Pobre vermezinho, eu disse, tu ainda vais morrer de frio aí embaixo, e joguei a criança às chamas. ${ }^{222}$
}

${ }^{222}$ SCHILLER, F., op. cit., p. 109. 
Foge da companhia daqueles com quem não queres parecer. ${ }^{*}$ Rodeado de facínoras, em meio ao caos gerado pela explosão da torre, o bandoleiro Moor começa a perceber que seu projeto de autonomia o levou à completa perda de controle sobre a vida. "Por essa efetivação, justamente, a lei do coração deixa de ser lei do coração. Nela recebe, com efeito, a forma do ser, e agora é potência universal, à qual esse coração é indiferente; de modo que o indivíduo, pelo fato de estabelecer sua própria ordem, não a encontra mais como sua. Com a efetivação de sua lei, ele não produz sua lei; pois embora, em si, seja a sua, para o indivíduo é uma efetivação estranha. O que ele faz é enredar-se na ordem efetiva, como numa superpotência estranha, que, aliás, não só lhe é estranha, mas inimiga." 223 Se a forma da efetividade sempre supera o entendimento, o verdadeiro problema ético não pode ser a instauração positiva do desígnio da consciência por meio do ato, mas a obtenção de uma conciliação negativa com o outro em cada caso singular. Essa conciliação é a finalidade prática da ação. O desafio é percebê-la como finalidade consciente. A individualidade atinge a maturidade quando começa a pautar a ação pela eficácia do resultado, e não mais pelo extravasamento do ânimo. Este novo patamar de razão prática não se subtrai da exigência de moralidade, mas antes a redefine segundo um critério objetivo de conciliação com o universal. A virtude só logra ser realizada quando seu fim originário toma um conteúdo essencial da exterioridade.

Eis que se nos revela o sentido da transformação de caráter convocada pela experiência. Falando consigo mesmo na segunda pessoa, Moor finalmente deixa entrever o surgimento de um senso de responsabilidade moral:

\footnotetext{
Que culpa tenho eu nisso? Que culpa podes ter se a pestilência que mandas, a carestia a que obrigas, a maré que levantas destrói e engole o justo e o injusto? Quem pode ordenar à chama que ela não se espalhe também sobre a sementeira abençoada, quando deve destruir o ninho do vespão mata-cavalo? Oh... Causa-me asco ouvir falar da criança assassinada! Da mulher assassinada... do enfermo assassinado! Estes atos me derribam ao chão! Eles envenenam as obras mais belas que engendrei até agora... E eis que agora me curvo, rubro de vergonha e escarnecido ante os olhos do céu, depois de ter me atrevido a brincar com a clava de Júpiter, derribando pigmeus, quando devia aniquilar titãs... ${ }^{224}$
}

\footnotetext{
${ }^{223}$ HEGEL, G. W. F., op. cit., p. 262 (277).

${ }^{224}$ SCHILLER, F., op. cit., p. 110.

* RABELAIS, François, Gargântua e Pantagruel, livro 2, cap. VIII.
} 
Ao se insurgir contra a lei, ele se insurgiu erga omnes. O sangue de suas vítimas lhe atesta a existência de outros corações que também se agitavam de algum modo sob o jugo da opressão e o peso da necessidade. A consciência percebe que o verdadeiro fundamento da ordem estabelecida não é nem a perversão dos tiranos, nem o arbítrio da lei, nem a mentira dos frades. "Mas antes, ela encontra essa ordem vivificada pela consciência de todos, e como lei de todos os corações. Faz experiência de que a efetividade é uma ordem vivificada; e isso justamente porque ao mesmo tempo torna efetiva a lei de seu coração."225 A consciência pode até não consentir com a razão de ser da potência absoluta. "Mas aquilo em que a consciência não se reconhece já não é a necessidade morta, e sim a necessidade enquanto vivificada por meio da individualidade universal." 226

Assim, pelo choque estranho da consciência contra o estado do mundo, a supremacia da potência abstrata se revela enraizada na própria figura da individualidade, cujo conceito de liberdade (a lei do coração) se degenera em exercício ilimitado da vontade. "De uma parte, na resistência que a lei de um coração encontra na lei dos outros singulares, a ordem universal demonstra ser a lei de todos os corações. As leis vigentes são defendidas contra a lei de um indivíduo, porque não são uma necessidade morta e vazia, carente de consciência, e sim a universalidade e a substância espirituais. Nelas vivem como indivíduos, e são conscientes de si mesmos, aqueles para quem essas leis têm sua efetividade. E isso de tal modo, que embora queixando-se dessa ordem como se contrariasse sua lei interior, e mantendo contra ela as suposições [Meinungen] do coração, de fato estão pelo coração ligados a ela, como à sua essência, e tudo perdem se lhes for retirada, ou se dela se excluírem eles mesmos. Como nisso justamente consistem a efetividade e o poder da ordem pública, essa ordem se manifesta como a essência universalmente vivificada, igual a si mesma; enquanto a individualidade [se mostra] como sua forma." 227 Vimos que o processo de exteriorização negativa determina o caráter singular da individualidade. Agora vemos que o conteúdo positivo da potência absoluta, a essência do Eu idêntico, aquilo que se exterioriza sob formas determinantes, tem existência, em si, como produto da atividade de todos os indivíduos - e não como simples exteriorização de uma individualidade isolada. Esta é a dolorosa descoberta que

\footnotetext{
${ }^{225}$ HEGEL, G. W. F., op. cit., p. 264 (279).

${ }^{226}$ Ibid., p. 263-264 (279).

${ }^{227}$ HEGEL, G. W. F., op. cit., p. 266 (281-282).
} 
compartilhamos com Karl von Moor. A ordem pública só se sustenta na medida em que se comprova eficaz na organização prática da vida. Essa fundamentação da potência absoluta na legalidade imanente da sociedade civil não deve ser confundida com legitimação racional de qualquer poder empiricamente ordenado. Não se trata de demonstrar a necessidade da tirania para que o indivíduo concorde com a sua existência. Trata-se de questionar se o princípio da tirania não contaminou a bandeira revolucionária. Hegel considera que o indivíduo professa a mesma forma de racionalidade do despotismo quando se arroga o direito de obedecer exclusivamente a uma lei moral interior.

$\gamma$ ) Dom Quixote: a virtude e o curso do mundo

“- Fica a saber, Sancho, que um homem não é mais que outro, se não fizer mais que outro." 228 À figura que apregoa essa lição ao escudeiro, se chamada a explicar-se, não faltariam, decerto, os engenhosos argumentos com que costuma arrazoá-la. Afinal, que outra coisa mostram os exemplos de vultos insignes, retirados dos abundantes livros de cavalarias, senão que todos eles devem honra e grandeza às façanhas que cunharam seus epítetos? Dom Belianis, o cavaleiro mais ferido pelas armas, era também o mais perigoso a manejá-las. Em perícia, a julgar pelas narrativas dos sábios, autores desses livros, a ele só se tenha talvez equiparado o nunca bastante louvado Amadis de Grécia, Cavaleiro da Ardente Espada, "que de um único golpe de través rachara ao meio dois ferozes e descomunais gigantes." 229 São incontáveis, e mesmo infinitas, as histórias dessas vidas levadas a render castelos e donzelas, de que a triste figura lança mão quando lhe pedem por razões. “- E assim, ando por estas solidões e descampados em busca de aventuras, com a vontade esclarecida de oferecer o meu braço e a minha pessoa à mais perigosa que a sorte ponha em minha frente, para ajudar os fracos e os necessitados ${ }^{230}$." Sem dúvida, poder-se-ia questionar o quão esclarecida é essa vontade de armar-se cavaleiro: se ela não desconsidera as vicissitudes dos tempos, se não se deixa enredar por contos, por fantasias; se não subestima empecilhos, ou se não promete menos aventuras do que desventuras. A figura,

\footnotetext{
228 CERVANTES, Miguel de. O Engenhoso Fidalgo D. Quixote de la Mancha, parte I, cap. XVIII, p. 147.

${ }^{229}$ Ibid., parte I, cap. I, p. 39.

${ }^{230}$ Ibid., parte I, cap. XIII, p. 107.
} 
nesse caso, não se pouparia de uma respeitosa polêmica, porque não desdenha de justificar os seus fins também com palavras. Mas sua definitiva resposta está em esporear Rocinante e partir sem demora, rumo a reinos longínquos, a cujos senhores possa oferecer seus préstimos; e, sobretudo, em acorrer às demandas que lhe surjam no curso destes caminhos tortuosos. Porque ao fazer-se ativa, para assombro universal, a vontade tenaz deste legatário da Távola ganha a forma da efetividade e o movimento do mundo, no que revela o alcance e essência de seu esclarecimento: ser esclarecida o suficiente para pôr-se em prática. Independentemente de haver ou não gigantes ali onde todos enxergam apenas moinhos de vento, o fato é que a consciência que descobriu a essencialidade do agir tem de tomar a cargo a efetivação de si mesma, a despeito do modo como ela se representa o fundamento de sua conduta. Nesse dito solene a Sancho Pança, a força do que D. Quixote nos propõe consiste não em demonstrar a validade do preceito, mas viver a sua verdade.

Sim; há um disparate encerrado na sua tenção cavaleiresca. Todavia, que dizer de um disparate que sai ao mundo em busca de si próprio... e logra se encontrar? Pois como enfrentar com êxito a prova da realidade, sem suprir todos os requisitos da boa sensatez?

Quixote foi um cavaleiro andante. E isso é mais do que tresvariar. No curso e ao cabo de arremetidas e recuos, fazendo-se capaz de existir, ele dá aos seus fins uma imanência que desperta a razão para a necessidade de mudar de lado; perplexos, temos de abandonar o posto de observação e segui-lo, como fiéis escudeiros, pela experiência ativa que consuma o conteúdo do que então já não se pode denominar de quimera. Diz Hegel:

\footnotetext{
Com efeito, só a partir da ação [o indivíduo] aprende a conhecer sua essência originária que deve ser seu fim; mas para agir deve possuir antes o fim. Mas, por isso mesmo, tem de começar imediatamente, e sejam quais forem as circunstâncias; sem mais ponderações sobre o começo, o meio e o fim, deve passar à atividade, pois sua essência e sua natureza em-si-essente são princípio, meio e fim: tudo em um só. ${ }^{231}$
}

E após oito dias de cogitações, como se ouvisse esse conselho, munido de lança, montaria e celada, "D. Quixote não quis aguardar mais tempo para executar o que planeava, instando-o a falta que ele supunha que causava no mundo a sua demora, tais eram as injustiças que tencionava vingar, as injúrias para reparar, os desvarios para emendar, e

\footnotetext{
${ }^{231}$ HEGEL, G. W. Fenomenologia do Espírito, V, C-a - "O reino animal do espírito e a impostura - ou a Coisa mesma", p. 280 (297).
} 
abusos para corrigir e dívidas para serem pagas."232 Uma vez postas em movimento, implementando-se, as finalidades do agir revelam o sentido de sua aparente inadequação primeva. Ao longo do percurso, Quixote desafiará os veredictos que proclamam a vacuidade de suas metas, na medida em que elas direcionam, constitutivamente, a formação de seu caráter.

Se a clarividência é uma superstição, nada substitui a vida: a individualidade só vem a conhecer o verdadeiro conteúdo do destino no decurso da experiência em que ela própria o produz - tal como vemos suceder ao virtuoso cavaleiro, agora que encetou a marcha. Pois já "não tinha andado muito quando lhe pareceu que à sua direita, da espessura de um bosque que ali estava, saíam uns gemidos fracos, como de alguém que se queixasse, e mal os ouviu disse logo: - Graças dou ao céu pela mercê que me faz, pois não tarda a dar-me ensejo para eu poder cumprir com o que desejo à minha profissão, e onde poderei colher os frutos dos meus bons desejos. ${ }^{233}$ " Quixote acura os ouvidos, os gemidos não calam. Alguém, nas redondezas, encontra-se em apuros. Ele pressente a oportunidade de cumprir com seu dever de ofício. Quem seria o aflito a necessitar de proteção e ajuda?

"E, voltando as rédeas, encaminhou Rocinante para onde lhe pareceu que saíam os gemidos. E pouco depois de ter entrado no bosque, viu uma égua atada a uma azinheira e noutra um rapaz atado, nu da cintura para cima, de uns quinze anos, que era quem dava os gemidos, e não sem motivo porque estava a dar-lhe muitos açoites com um cinto de couro

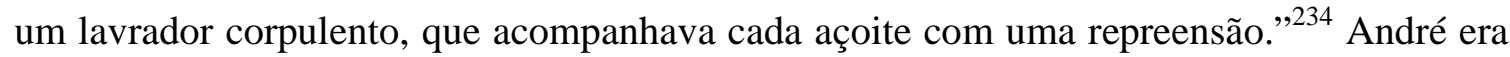
o nome do rapaz, que suportava, amarrado, os golpes e os desaforos. Seu amo o tinha por pastor relapso, e o punia com aquela agressão tão própria dos covardes. Ora, não havia ali uma clara injustiça? Surgiria porventura ocasião mais propícia para colocar em prática os princípios da cavalaria? Eis que D. Quixote decide intervir, irado, mostrando-se por detrás dos arbustos, e ordenando ao lavrador que cessasse de surrar o jovem. "O lavrador, que viu por perto de si aquela figura cheia de armas a brandir a lança sobre o seu rosto, julgou-se morto e com palavras calmas respondeu: - Senhor cavaleiro, este rapaz que estou a castigar é meu criado, que me serve para guardar um rebanho de ovelhas que tenho nestas terras, que é tão desleixado que todos os dias me falta uma; e, porque eu castigo o seu descuido,

\footnotetext{
${ }^{232}$ CERVANTES, Miguel de., op. cit. , parte I, cap. II, p. 42.

${ }^{233}$ Ibid., parte I, cap, IV, p. 53.

${ }^{234}$ Ibid., parte I, cap, IV, p. 53.
} 
ou velhacaria, ele diz que o faço por ser mesquinho, para não lhe pagar a soldada que lhe devo; e por Deus e pela minha alma que ele mente.”235

Mas não no depoimento dos iníquos se há de fiar o cavaleiro andante. Pois então o carrasco é ainda devedor da sua vítima, além de maltratá-la! E, pelo seu modo de moderar o tom, já se nota como, contra a espada da justiça, o insolvente não se atreve a usar da mesma prepotência que reserva para os pequenos e inermes. Infenso àquelas arengas de ocasião, D. Quixote manda soltar o menino e lhe pagar a soldada, sem mais réplicas. "O lavrador baixou a cabeça e, sem responder palavra, desatou o criado, ao qual D. Quixote perguntou quanto lhe devia o seu amo. Ele disse que nove meses, a sete reais cada mês. Fez a conta D. Quixote e achou que eram setenta e três reais, e disse ao lavrador que imediatamente os desembolsasse, se não queria morrer por isso." ${ }^{236}$ Ocorre, entretanto, que o lavrador não trazia consigo a quantia necessária para saldar a obrigação, ou pelo menos foi isso o que alegou a seguir, mas que reconhecia a dívida, e a compensaria de bom grado, tão logo André se dispusesse a acompanhá-lo à casa onde ele guardava seu dinheiro - ao que o rapaz, desconfiado, hesitou. Pareceu bem a D. Quixote que o lavrador assim fizesse, desde que o jurasse pela lei da cavalaria, como ele mesmo já se propunha, e determinou: “"- Pagai tudo em boas moedas de prata, que com isso me satisfaço; e olhai que tendes de fazer como jurastes; senão, pelo mesmo juramento vos juro voltar a procurar-vos e castigar-vos, e que hei-de achar-vos, ainda que vos escondais mais que uma lagartixa. E se quereis saber quem isto manda, para ficardes mais seriamente obrigado a cumpri-lo, sabei que sou o valoroso D. Quixote de la Mancha, o reparador de injustiças e ofensas, e ficai com Deus, e não se vos apague da memória o prometido e o jurado, senão se cumpre o que mandar a sentença pronunciada.' E ao dizer isto, esporeou Rocinante e em pouco tempo afastou-se deles." ${ }^{237}$

As aventuras mal haviam começado; dali em diante, muitas outras demandas ainda cruzariam seu caminho. Deste episódio precoce partira D. Quixote com a certeza do dever cumprido, e prova a história que ele sempre o teve em alta conta, pois nunca se esqueceu dele, embora se multiplicassem os seus feitos e crescesse a sua fama; e certa vez o rememorou aos convivas, "para que vejam vossas mercês como é importante haver

\footnotetext{
${ }^{235}$ Ibid., parte I, cap, IV, p. 53.

${ }^{236}$ Ibid., parte I, cap, IV, p. 54.

${ }^{237}$ Ibid., parte I, cap, IV, p. 54.
} 
cavaleiros andantes no mundo." ${ }^{, 238}$ Foi quando se haviam apeado junto a uma fonte para saciar a fome, antes de prosseguir o cortejo, e calhou a D. Quixote ser agarrado pelas pernas, por alguém que se achegara de repente, e ali aos seus pés, em prantos, fazia ouvir alguns murmúrios sugestivos: “- Ai, meu senhor! Não me conhece vossa mercê? Pois olheme bem, que eu sou André, aquele rapaz que vossa mercê soltou da azinheira onde estava amarrado."239

Após tantas jornadas, uma antiga personagem ressurgia para prestar contas da sorte que tivera. D. Quixote logo puxou o caso pela memória, que a tinha muito boa, e não desperdiçou o ensejo de se vangloriar daquela antiga aventura que ele entendia tão bem comprovar a importância da cavalaria, e cujos detalhes já relatava a todos os presentes.

“ - Tudo o que vossa mercê disse é muito verdade - respondeu o rapaz -; mas o negócio teve uma conclusão muito ao contrário do que vossa mercê imagina. - Como é que foi ao contrário? - replicou D. Quixote. - Depois, aquele vilão não te pagou? - Não só não me pagou - respondeu o rapaz -, mas logo que vossa mercê saiu do bosque e eu e ele ficamos sós, voltou a atar-me à mesma azinheira, e deu-me de novo tantos açoites que fiquei feito num S. Bartolomeu esfolado; e a cada açoite que me dava, dizia-me uma graçola e zombaria a fazer pouco de vossa mercê, que, se eu não sentisse tantas dores, terme-ia rido do que ele dizia. Na verdade, ele deixou-me num estado tal que até agora tenho andado a tratar-me num hospital do mal que aquele homem tão ruim então me fez. De tudo isto tem vossa mercê a culpa, porque se tivesse seguido o seu caminho e não se metesse onde não era chamado, nem se intrometesse nos assuntos alheios, o meu amo tinha-se contentado com dar-me uma ou duas dúzias de açoites e depois soltava-me e pagava-me o que devia. Mas como vossa mercê o ofendeu sem nenhum motivo, e lhe disse tantos insultos, a sua cólera inflamou-se, e como não pôde vingá-la em vossa mercê, quando se viu sozinho descarregou em mim toda a tempestade, de modo que me parece que não voltarei a ser homem em toda a minha vida., 240

Diante do depoimento, D. Quixote não pôde esconder seu embaraço. Ele, que interviera no caso para ajudar o pobre rapaz, deparava-se agora, envergonhado, com um resultado não apenas imprevisto, mas contrário aos seus nobres intentos! E, no entanto, se o

\footnotetext{
${ }^{238}$ Ibid., parte I, cap. XXXI, p. 283.

${ }^{239}$ Ibid., parte I, cap. XXXI, p. 283.

${ }^{240}$ Ibid. parte I, cap. XXXI, p. 284.
} 
que ele fez não fosse aquilo que tinha a intenção de fazer, então nem sequer poderia ter agido. Quixote terá de arcar com os risos do público e as dores de André. “- Por amor de Deus, senhor cavaleiro andante, se me encontrar outra vez, ainda que veja que estão a fazerme em pedaços, não me socorra nem ajude, mas deixe-me com a minha desgraça, que não será tanta, que não seja maior a que me virá da ajuda de vossa mercê, a quem Deus maldiga, e a todos os cavaleiros andantes que nasceram no mundo."241

Os romanos, que fundaram o direito moderno, já sabiam o que define a exteriorização negativa. Alienatio est omnis actus per quem dominium transfertur. ${ }^{*}$ Ao constatar que prática se impõe universalmente para o sujeito como uma perda de autonomia, o principal problema que Hegel se propõe a resolver não é o de gerir essa sociedade civil baseada na alienação, mas o de converter a experiência da individualidade em campo de autenticidade. Essa determinação está enunciada no conceito hegeliano de experiência:

Experiência é justamente o nome desse movimento em que o imediato, o não-experimentado, ou seja, o abstrato - quer do ser sensível, quer do Simples apenas pensado - se aliena e depois retorna a si dessa alienação; e por isso - como é também propriedade da consciência - somente então é exposto em sua efetividade e verdade. ${ }^{242}$

Se a conduta moral não pode ser extraída de nenhum preceito teórico, o indivíduo que se lança ao resgate da autonomia deve estar preparado para uma contínua reflexão sobre a prática. Hegel nos convoca a pensar o sentido dessa busca, e Quixote se apresenta como exemplo maior dela. Sua figura nos fornece a experiência universal da individualidade consciente de si que se defronta com o próprio destino a cada tentativa de se efetivar segundo seus critérios de conduta.

Os encontros com o destino são sentidos como choques. Os fins, almejados em consciência, precisam tomar meios da exterioridade: a consecução do ato não permite que eles permaneçam sempre iguais. Nesses abalos, o desafio de prosseguir testa a energia do caráter para suportar reavaliações de propósitos - não no sentido de restringi-los a limites universais previamente instituídos, mas no de refundá-los segundo exigências de universalidade que afloram, e que restam por instituir.

\footnotetext{
${ }^{241}$ Ibid. parte I, cap. XXXI, p. 284-285.

${ }^{242}$ HEGEL, G. W., Fenomenologia do Espírito, Prefácio, p. 46 (38-39).

* Alienação é todo ato pelo qual se transfere o domínio.
} 
A individualidade, portanto, vive o dilaceramento de tentar ser para o outro o que ela é para si mesma, e nisto a sua essência se explicita. Ela vem a ser para si trazendo à luz do dia o seu próprio conteúdo; e não raro recalcitra, ofuscada. E eis que chegamos ao ponto de tensão. A verdadeira liberdade requer a supressão da potência abstrata: pois é a eterna insubsistência de disposições indeterminadas o que escraviza o homem à certeza do que ele não é. Porém, antes de tudo, ousar perseguir o destino é recusar-se a acatá-lo. A infusão na efetividade nunca exaure a centelha negativa, que no resguardo interior, do contrário, antes se atiça de desejo de queimar; crepitando, ante os meios disponíveis, resta ali, depurada, a sublevação subjetiva contra as contingências, que é condição de todo movimento real. A educação para a liberdade jamais poderia abdicar de seu mais valioso princípio - mesmo porque, afinal, é a ele tão-somente que visa a inculcar: ter, por ser ativo, consciência de si enquanto perpétua e irredutível possibilidade de efetivação - lição que o singular cavaleiro manchego, tão acusado de exceder-se, mostrou ter muito bem absorvido, naquela ocasião em que o instaram a usar o velho nome de fidalgo pacato e arraigado, em vez da famosa alcunha que adotara para honra de sua terra: “- Eu sei quem sou - respondeu D. Quixote -, e sei que posso ser não só os que eu disse, mas todos os Doze Pares de França, e ainda todos os Nove da Fama, pois todas as façanhas que todos juntos e cada um sozinho fizeram não valem tanto como as minhas." 243

\footnotetext{
${ }^{243}$ CERVANTES, Miguel de., op.cit., parte I, p. 60.

Os Doze Pares de França eram os cavaleiros iguais entre si (portanto, pares) e os melhores do imperador Carlos Magno (entre os quais Roldão, Oliveiros, Valdovinos, Reinaldo de Montalvão) cantados na Chanson de Roland (fins do século XI). Os Nove Cavaleiros da Fama constituem um conjunto divulgado pelas Voeux du paon de Jacques de Longuyon (1312): eram três judeus (Josué, David e Judas Macabeu), três greco-latinos (Heitor, Alexandre e Júlio César) e três cavaleiros recentes (o rei Artur, o imperador Carlos Magno e Godofredo de Bouillon). [Nota do tradutor José Bento]
} 


\title{
CONCLUSÃO
}

Quando William Harvey (1578-1657) descreveu o sistema circulatório, sobreveiolhe a acusação escolástica de violar a integridade do homem não simplesmente por ele haver dissecado cadáveres, mas, sobretudo, por haver apresentado o coração como um fundamento orgânico para o funcionamento do corpo, abandonando o preceito aristotélico de que a alma seria a força motriz da fisiologia humana. Dada a ascendência igualmente aristotélica das principais inflexões teóricas examinadas ao longo do presente estudo, convém frisar, a título de conclusão, que a crítica hegeliana à representação dualista do homem não deve ser confundida com inquisição teológica à ciência experimental. Antes de pespegar em Hegel o rótulo de escolástico tardio, lembremo-nos de seu esforço para destituir a fundamentação metafísica da subjetividade, incluída aí a noção de alma como emissária de uma substância incorpórea superior. Lukács explica a natureza peculiar do princípio anímico em que Hegel deposita a essência absoluta da individualidade:

\begin{abstract}
Na Fenomenologia, Hegel expõe o processo através do qual a consciência do homem surge da interação entre suas aptidões internas e o mundo ambiente, o qual foi em parte gerado por sua própria atividade, em parte dado por natureza; além disso, expõe como essa consciência - após inter-relações análogas, mas de tipo mais elevado - se desenvolve até chegar à autoconsciência; e mostra também como, desse desenvolvimento do homem, deriva o espírito enquanto princípio determinante do caráter essencial do gênero humano. (...) Quando Hegel pretende atribuir a tal relação uma figura ontologicamente autônoma, chamando-a de espírito, ainda não se afasta em princípio da verdade objetiva, já que efetivamente o ser social - deixando de lado o que ele é em-si - tem uma existência independente da consciência individual do homem singular, possuindo em face dessa consciência um alto grau de dinamismo autonomamente determinado e determinante. E essa autonomia não é alterada pelo fato de ser o movimento do ser social uma síntese das ações, dos esforços etc. individuais; se é verdade que essas ações e esforços partem imediatamente (mas só imediatamente) da consciência do indivíduo, também é verdade que suas causas e conseqüências são muito diferentes daquelas que - ao empreender tais ações etc. - os indivíduos pensaram, sentiram e quiseram. Se tal estrutura já se manifesta no caso da consciência individual, que porém só pode nascer num contexto social, muito mais se manifestará - e sob formas qualitativamente superiores - nos casos em que atos individuais diferentes, articulando-se indissoluvelmente entre si, produzam um movimento social, independentemente do fato dos indivíduos em ação terem ou não em vista se apoiarem ou se atritarem. Por isso, do ponto de vista de uma ontologia do ser social, é absolutamente legítimo atribuir a essa totalidade, a essa conexão dinâmico-contraditória de atos individuais, um ser sui generis. $^{244}$
\end{abstract}

A partir do momento em que o campo da experiência se revela condicionado pelo espírito, é legítimo recolocar a pergunta sobre o grau de autonomia a que pode aspirar um

\footnotetext{
${ }^{244}$ LUKÁCS, Georg, A falsa e a verdadeira ontologia de Hegel, p. 31.
} 
único indivíduo, em face da posição ocupada por ele no todo. Por um lado, percebemos que a filosofia hegeliana conduz a uma diluição da oposição entre subjetividade e objetividade, que culmina com o abandono da perspectiva do entendimento. Vista de cima, a autoefetivação da individualidade transcorre segundo uma perfeita convergência entre os atos singulares e o devir da substância. "O movimento da individualidade que se cultiva [der sich bildenden Individualität] é, pois, imediatamente, o vir-a-ser dessa individualidade como essência objetiva universal, quer dizer, como o vir-a-ser do mundo efetivo." ${ }^{245}$ No desenvolvimento, os indivíduos se distinguem uns dos outros pela energia do caráter, pela extensão com que se apropriam da exterioridade, mas nem por isso eles deixam de ser manifestações de uma mesma essência absoluta. "O que se manifesta aqui como a força do indivíduo - pela qual a substância seria subjugada e com isso superada - é o mesmo que a efetivação da substância. Com efeito, a força do indivíduo consiste em ajustar-se à substância, quer dizer, em extrusar-se [sich entäussern] de seu si, e pôr-se assim como substância essente objetiva. A cultura [Bildung] e a efetividade própria do indivíduo é portanto a efetivação da substância mesma." 246 Mas isso não significa que, na concepção hegeliana, o indivíduo esteja predestinado a servir de instrumento para realização de supostas finalidades da substância. Em consonância com o caráter constitutivo e singularizante da exteriorização negativa - ponto em que insistimos particularmente neste estudo - o fato de os indivíduos possuírem a mesma essência e de se desenvolverem em um campo de experiência delimitado previamente pelo espírito implica restrição a sua autonomia apenas no sentido estrito de que ao indivíduo não é dado produzir integralmente todas as condições de sua própria existência. Por isso Hegel contesta todo conceito de liberdade que se baseia na onipotência da subjetividade para engendrar o mundo. Seria falso conceber a exteriorização como um fiat lux.

Ocupamo-nos desse último aspecto do pensamento hegeliano na discussão sobre a auto-efetivação da consciência-de-si racional. Com efeito, os princípios de autonomia sucessivamente derrubados pela experiência das três figuras literárias da individualidade podem ser subsumidos a uma filosofia moral para qual a reconciliação com a objetividade se dá pela efetivação do eu puro enquanto tal, pela ação ética incondicional. Na Estética,

\footnotetext{
${ }^{245}$ HEGEL, G. W. F., Fenomenologia do Espírito, VI, B, a - "A cultura e o seu reino da efetividade”, p. 341 (365).

${ }^{246}$ Ibid., p. 341 (365).
} 
Hegel relembra o caso exemplar. "Karl Moor, ofendido pela ordem existente e por homens que abusam do poder desta ordem, sai do círculo da legalidade e, na medida em que possui a audácia de romper com as barreiras [Schranken] que o sufocam e assim propriamente criar para si um novo estado heróico, transforma-se em restaurador do direito e vingador autônomo da injustiça, da inclemência e da opressão. Mas, por um lado, tem de resultar pequena e isolada esta vingança privada devido à insuficiência dos meios necessários; e, por outro, ela apenas pode levar ao crime, já que encerra em si mesma a injustiça que pretende destruir. Da parte de Karl Moor, trata-se de um infortúnio, de um erro, e mesmo que também seja trágico, apenas meninos podem ser seduzidos por este ideal de bandidos." 247 Contra os flagelos trazidos pela tirania da virtude, e para contornar as armadilhas do destino, Hegel nos propõe reconhecer que nenhum ato é imune à contradição, e que a crença no ideal absoluto costuma ser apenas o prenúncio da incoerência. Na Estética, ainda, a tese de que a autonomia individual só pode ser exercida em condições propícias é amplamente desenvolvida no diagnóstico sobre o prosaísmo da vida moderna. Hegel constata que a instauração do estado político retirou do indivíduo o direito de atuar em função da justiça e de dirimir conflitos segundo os atributos de sua própria personalidade, sua bravura, temperança, perspicácia, força, destreza etc. "Pois apenas a cavalaria e o sistema feudal são, na Idade Média, o terreno autêntico para esta espécie de autonomia. Mas se a ordem legal se constitui de modo mais completo em sua forma prosaica e se tornou predominante, a autonomia aventureira dos indivíduos cavalheirescos sai de relação e, se ela ainda quer afirmar-se a si como o que é unicamente válido, regular a injustiça no sentido da cavalaria e proporcionar ajuda aos oprimidos, ela se torna ridícula como Dom Quixote, tal como descreve Cervantes. ${ }^{248}$ Apesar de ridícula, a conduta quixotesca, se tomada em sua complexidade, não deixa de representar um avanço positivo e de conter um ganho de consciência em direção à crítica da ética formalista. Infelizmente não estamos em ocasião de comprovar essa asserção com elementos da obra cervantina, mas podemos associá-la, de passagem, à conhecida opinião de Hegel sobre a superioridade do registro cômico para exprimir seriamente a situação do homem no mundo moderno.

\footnotetext{
${ }^{247}$ HEGEL, G. F., Cursos de Estética I, Terceiro Capítulo, B, II, 1, c - “A reconstrução da autonomia individual", p. 203-204. Tradução de Marco Aurélio Werle.

248 Ibid., p. 204-205.
} 
Por outro lado, seria desonesto omitir que, embora apreciasse as tentativas de resgate da autonomia individual em matéria de estética, Hegel não nutria esperança pela sua realização prática no âmbito da moderna sociedade civil. Mencionemos, a propósito, as palavras soturnas que encerram o Prefácio da Fenomenologia do Espírito:

\begin{abstract}
Vivemos aliás numa época em que a universalidade do espírito está fortemente consolidada, e a singularidade, como convém, tornou-se tanto mais insignificante; em que a universalidade se aferra a toda a sua extensão e riqueza acumulada e as reivindica para si. A parte que cabe à atividade do indivíduo na obra total do espírito só pode ser mínima. Assim ele deve esquecerse, como já o implica a natureza da ciência. Na verdade, o indivíduo deve vir-a-ser, e também deve fazer, o que lhe for possível, mas não se deve exigir muito dele, já que muito pouco pode esperar de si e reclamar para si mesmo. ${ }^{249}$
\end{abstract}

Certamente não faltou quem acusasse esse prognóstico, sem dúvida realista, de pecar pela resignação. Afinal, se o espírito da época reduziu à insignificância justamente o indivíduo, que é o fundamento de sua enorme riqueza, então não haveria ainda, neste mundo, uma contradição remanescente a ser resolvida?

\begin{abstract}
Mas Hegel jamais foi um sonhador, um visionário, um construtor de projetos para o futuro, como muitos dos seus contemporâneos célebres; era um filósofo com alentado e amplo sentido de realidade, com uma fome tão intensa de realidade autêntica como talvez, depois de Aristóteles, não seja possível encontrar em nenhum outro pensador. Praticamente não existe nenhum setor da realidade ou do saber que tenha deixado de provocar seu apaixonado interesse filosófico; e ele, ao mesmo tempo que a apropriação dos próprios fatos, colocava no centro do seu interesse a construção categorial dos mesmos. Assim, nasceu não apenas seu saber universal; ele foi levado a se tornar cada vez mais profundamente consciente da contraditoriedade intrínseca à estrutura e à dinâmica de todos os objetos, relações e processos. $^{250}$
\end{abstract}

Lukács considera que "a tentativa hegeliana de conceber e representar o mundo do homem como um mundo imanente, auto-criado, é aquilo que de mais grandioso foi feito nessa direção até aquele momento. ${ }^{, 251}$ E alude ao curioso destino histórico do influente pensador: "em um primeiro momento pareceu que ele tivesse posto termo ao pensamento filosófico, que o tivesse levado às últimas instâncias, quando na realidade era um descobridor de territórios inexplorados, cujas observações tiveram alcance secular (...)., ${ }^{, 252}$

\footnotetext{
${ }^{249}$ Id., Fenomenologia do Espírito, Prefácio, p. 70.

${ }^{250}$ LUKÁCS, Georg, op. cit., p. 28.

${ }^{251}$ Ibid., p. 30.

${ }^{252}$ Ibid., p. 65.
} 
No que diz respeito às repercussões gerais da filosofia hegeliana e à sua posição na história da filosofia, eis o que esperamos ter mostrado fartamente ao longo das páginas precedentes:

\begin{abstract}
Hegel nega toda espécie de prioridade do dever-ser em relação ao ser. Isso empresta às suas considerações - e não apenas sobre a sociedade e a história - uma notável objetividade, que se situa acima das intenções e dos desejos. Já nisso está presente a nova ontologia, cuja adequada compreensão é a meta última de todo o seu pensamento: ou seja, a posição central e máxima da realidade no sistema categorial global, a supremacia ontológica do ser-precisamente-assim da realidade com relação a todas as demais categorias, subjetivas e objetivas. A grandeza de Hegel como pensador liga-se, não em último lugar, ao fato de ter por vezes advertido com extrema clareza esse problema ontológico e de ter tentado captá-lo conceitualmente em todas as suas conseqüências. $^{253}$
\end{abstract}

Vimos como Kant se desdobrava para salvar o princípio supremo do menor contato com o campo da experiência. Ao sustentar que um juízo empírico seja uma proposição analítica, Kant nada mais faz do que atribuir dois nomes diferentes a uma mesma coisa para distingui-la de si mesma em um plano meramente teórico. Pela avaliação de Lukács, percebemos por que Kant não podia suportar as conseqüências da negação determinada. Pois ao cabo dessa refutação sistemática de qualquer apriorismo,

(...) não apenas se reconhece um nível de mobilidade dialética até então desconhecido, mas a totalidade da imagem do mundo sofre uma reviravolta ontológica: a partir do momento em que, para o absoluto, vale a mesma lei da processualidade dialética que vale para todo o mundo da finitude, desaparece a diferença (ou a oposição) entre aquém e além, se é que a ontologia dialética deve ser levada adiante com coerência. Com isso, todos os objetos (os processos) do aquém, da finitude, do terrenal etc. adquirem - em última instância - a mesma estrutura ontológica do próprio absoluto. As graduações no interior dessa homogeneidade dialética última e universal não sofreram nenhuma alteração importante em sua estrutura de base. A vitória ontológica da processualidade contraditória universal eleva essa concepção unitária da realidade global a um nível qualitativamente superior a qualquer outra tentativa anterior. ${ }^{254}$

E assim, em matéria de pensamento, erguendo-se majestosamente contra a propalada incognoscibilidade da coisa-em-si, Hegel nos legou o direito e o desafio de produzir a inteligibilidade da essência - mérito cuja força e sustentação convidam a uma relação respeitosa, e que não pode ser afastado com base em acusações esporádicas ou percepções contingentes.

\footnotetext{
${ }^{253}$ Ibid., p. 17.

${ }^{254}$ Ibid., p. 69.
} 
Não se trata de supor que afirmações singulares, colocações metodológicas singulares etc. de Hegel sejam justas, enquanto outras seriam insustentáveis. Em suma, não é possível separar tranqüilamente "o que é vivo" e "o que é morto" em seu sistema; ao contrário, os aspectos justos e os aspectos equivocados apresentam-se nele unidos e ligados de modo indissolúvel; separá-los, mostrar onde o seu pensamento se orienta pelo caminho que leva à filosofia do futuro e onde, ao contrário, desemboca no beco sem saída do que se atrofiou, eis uma tarefa que deve ser feita, por assim dizer, para cada problema individual importante tomado isoladamente. ${ }^{255}$

Com efeito, tal era o que nos propuséramos ao escolher a categoria da individualidade para objeto do presente estudo, agora finalmente acabado.

${ }^{255}$ Ibid., p. 23. 


\section{BIBLIOGRAFIA}

AUERBACH, Erich. Mimesis: a representação da realidade na literatura ocidental. São Paulo: Perspectiva, 1976

__ . "Dulcinéia Encantada", In Mimesis: a representação da realidade na literatura ocidental. São Paulo: Perspectiva, 1976

BLOCH, E. "Das Faustmotiv der Phänomenologie des Geistes", In: Hegel-Studien I, Leipzig, 1961

BOURGEOIS, Bernard. O pensamento político de Hegel. São Leopoldo: UNISINOS, 2000 . Hegel: os atos do Espírito. São Leopoldo: UNISINOS, 2004

CERVANTES, Miguel de. O Engenhoso Fidalgo D. Quixote de la Mancha. Lisboa: Relógio d'Água Editores, 2005

DESCARTES, René. Oeuvres Philosophiques. Paris: Éditions Garnier, 1963 . Regras para a Orientação do Espírito. São Paulo: Martins Fontes, 1999 . Princípios da Filosofia. Lisboa: Edições 70, 1997

FICHTE, Johann Gottlieb. Lições sobre a vocação do sábio e Reivindicação da Liberdade de Pensamento. Lisboa: Edições 70, 1999

_. "Recensão de Enesidemo", In A recepção da Crítica da Razão Pura. Lisboa: Fundação Calouste Gulbenkian, 1992

. "Primeira Introdução à Doutrina da Ciência", In A recepção da Crítica da Razão

Pura. Lisboa: Fundação Calouste Gulbenkian, 1992

. "Segunda Introdução à Doutrina da Ciência", In A recepção da Crítica da Razão

Pura. Lisboa: Fundação Calouste Gulbenkian, 1992 
GOETHE, Johann Wolfgang von. Goethes Werke. Hamburg: Erich Trunz, 1949-1960 . Fausto. São Paulo: Editora 34, 2004 . Os sofrimentos do Jovem Werther. São Paulo: Martins Fontes, 1996 . Escritos sobre Arte. São Paulo: Associação Editorial Humanitas e Imprensa Oficial do Estado de São Paulo, 2005

HEGEL, Georg Wilhelm Friedrich. Werke. Auf der Grundlage der Werke von 1832-1845 neu edierte Ausgabe. Frankfurt am Main: Suhrkamp, 1986 . Cursos de Estética I. São Paulo: Ed. USP, 2001 Cursos de Estética II. São Paulo: Ed. USP, 2000 . Cursos de Estética III. São Paulo: Ed. USP, 2003 . Cursos de Estética IV. São Paulo: Ed. USP, 2003 . Fenomenologia do Espírito. Petrópolis: Ed. Vozes, 2005 . Fé e Saber. São Paulo: Hedra, 2007 . Enciclopédia das Ciências Filosóficas em Compêndio. São Paulo: Edições Loyola, $1995 / 1997$ . Princípios da Filosofia do Direito. São Paulo: Martins Fontes, 2000

HELLER, Agnes. Aristóteles y el Mundo Antiguo. Barcelona: Ed. Península, 1983

HYPPOLITE, Jean. Gênese e estrutura da Fenomenologia do Espírito. São Paulo: Discurso Editorial, 1999

JAESCHKE, Walter. Hegel Handbuch. Stuttgart/Weimar: Verlag J.B. Metzler, 2003

KANT, Immanuel. A paz perpétua e outros opúsculos. Lisboa: Edições 70, 2002 . Crítica da Razão Pura. São Paulo: Ed. Nova Cultural, 1999

KOJÈVE, Alexander. Introdução à leitura de Hegel. Rio de Janeiro: Contraponto, 2000 
LEBRUN, Gérard. "Hegel e a ingenuidade cartesiana", In: Analytica Rio de Janeiro $n^{o} 1$, vol. 3, 1998

LUKÁCS, Georg. A falsa e a verdadeira ontologia de Hegel. São Paulo: Livraria Editora Ciências Humanas, 1979

. Der junge Hegel. Ebner, Ulm: Suhrkamp, 1973

MARKET, Oswaldo. "Johann Gottlieb Fichte. Estudo introdutório, notas e bibliografia”, In A recepção da Crítica da Razão Pura. Lisboa: Fundação Calouste Gulbenkian, 1992

MOURÃO, Ronaldo Rogério de Freitas. "O animal filosófico”, In Entre Clássicos, São Paulo, v. 6, p. 74-83, 2006

PINKARD, Terry. Hegel - a biography. Cambridge: Cambridge-USA, 2002

ROSENZWEIG, Franz. Hegel e o Estado. São Paulo: Perspectiva, 2008

SAFATLE, Vladimir Pinheiro. Cinismo e Falência da Crítica. São Paulo: Boitempo, 2008

SCHILLER, Friedrich von. Sämtliche Werke in 5 Bänden. München: Winkler Weltliteratur Dünndruck-Ausgabe, 1976-1980

Die Räuber. Stuttgart: Phillip Reclam jun. GmbH \& Co., 1992

.Os Bandoleiros. Porto Alegre: L\&PM Editores, 2001

SIEP, Ludwig. Der Weg der Phänomenologie des Geistes, In: Hegels Philosophie. Kommentare zu den Hauptwerken, Band 1, Darmstadt, WBG, 2000

VIEIRA, Maria Augusta da Costa. "Heroísmo e Marginalidade: heranças quixotesca”, In Língua e Literatura, São Paulo, n. 24, p. 67-75, 1998

WATT, Ian. Mitos do Individualismo Moderno - Fausto, Dom Quixote, Dom Juan, Robinson Crusoé. Rio de Janeiro: Jorge Zahar Editor, 1997 
WERLE, Marco Aurélio. A poesia na Estética de Hegel. São Paulo: Associação Editorial Humanitas, 2005

. "Literatur und Individualität. Zur Verwirklichung des Selbstbewußtseins durch sich selbst”, In Hegels Phänomenologie des Geistes. Ein kooperativer Kommentar zu einem Schlüsselwerk der Moderne Herausgegeben von Klaus Vieweg und Wolfgang Welsch. Frankfurt am Main: Suhrkamp, 2008

WIESE, Benno von. Die deutsche Tragödie. Von Lessing bis Hebbel. München: Deutschen Taschenbuch Verlag, 1983 